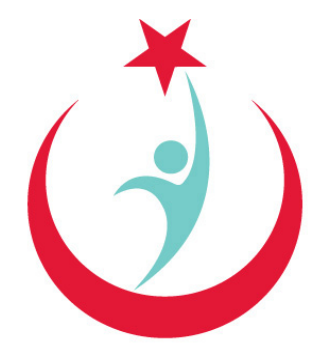

T.C.

SAĞLIK BAKANLIĞI

TÜRKIYE HALK SAĞLIĞI KURUMU

T.R.

THE MINISTRY OF HEALTH

PUBLIC HEALTH INSTITUTION OF TURKEY

ISSN 0377-9777 (Basılı / Printed)

ISSN 1308-2523 (Çevrimiçi / Online)

\title{
TÜRK HIJJYN
}

\section{ve \\ DENEYSEL BIYOLOJI DERGISI}

\section{TURKISH BULLETIN OF HYGIENE AND EXPERIMENTAL BIOLOGY}

Turk Hij Den Biyol Derg 


\section{TÜRK HIJYYN ve DENEYSEL BIYOLOJI DERGISI}

\section{TURKISH BULLETIN OF HYGIENE AND EXPERIMENTAL BIOLOGY}

\section{Sahibi / Owner}

Türkiye Halk Sağlığı Kurumu adına

On behalf Public Health Institution of Turkey

Mustafa AKSOY, Başkan

Mustafa AKSOY, President

EDITÖR / EDITOR IN CHIEF

Ayșegül TAYLAN-ÖZKAN

EDITÖR YARDIMCILARI / DEPUTY EDITORS

Demet CANSARAN-DUMAN

Yavuz UYAR

YAYIN KURULU / EDITORIAL BOARD

Sühendan ADIGÜZEL

Fatih BAKIR

Mehmet Kürșat DERici

Mestan EMEK

Arsun ESMER

Sibel KARACA

Pinar KAYNAR

ÖZcan ÖZKAN

Pınar ÜNAL

Gerard A. van ZOELEN

TEKNIK KURUL / TECHNICAL BOARD

Murat BAYRAM

Murat DUMAN

Zeynep KÖSEOĞLU

Selahattin TAŞOĞLU

\section{TÜRKIYE HALK SAĞLIĞI KURUMU}

\section{PUBLIC HEALTH INSTITUTION OF TURKEY}

\section{ANKARA-TÜRKIYE}

Yılda dört kez yayınlanır / Published four times per year

Asitsiz kağıt kullanılmıştır / Acid free paper is used

Baskı ve Cilt / Press and Binding :

Kayıhan Ajans

Hoşdere Cad. No: 201/9 Çankaya-ANKARA

Tel: 03124427272

e-posta: kayihanajans@gmail.com
Yayın Türü / Type of Publication :

Yerel Süreli Yayın / Periodical Publication

Basım Tarihi / Date of Publication :

Mayıs 2012 / May 2012 


\section{TÜRK HIJYYEN ve DENEYSEL BIYOLOJI DERGISI TURKISH BULLETIN OF HYGIENE AND EXPERIMENTAL BIOLOGY}

\section{BILIMSEL DANIŞMA KURULU / SCIENTIFIC ADVISORY BOARD}

Adil ALLAHVERDIYEV, Yıldız Tek. Üniv., Kimya Fak., İstanbul

Ahmet ÇARHAN, Türk Akreditasyon Kurumu, Ankara

Ahmet KART, Hacettepe Üniv., Tip Fak., Ankara

Akçahan GEPDIREMEN, Abant İzzet Baysal Üniv., Tıp Fak., Bolu

Ali ALBAY, GATA, Ankara

Ali MiRAZiMi, Swedish Inst. for Infect. Dis. Control, Sweden

Alper AKÇALI, 18 Mart Üniv., Tıp Fak., Çanakkale

Anna PAPA, Aristotle Univ., Medical School, Thessaloniki, Greece

Aşkın YAŞAR, Ankara Üniv., Vet. Fak., Ankara

Ayhan FiLAZİ, Ankara Üniv, Vet. Fak., Ankara

Aykut ÖZKUL, Ankara Üniv., Vet Fak., Ankara

Ayşen GÜNEL-ÖZCAN, Hacettepe Üniv., Tıp Fak., Ankara

Aziz SANCAR, Univ. North Carolina, Dep Bipchem E Biophysics, USA

Bahadır GÖNENÇ, Ankara Üniv., Vet. Fak., Ankara

Banu ÇAKIR, Hacettepe Üniv., Tıp. Fak., Ankara

Berrin ESEN, RSHMB, Ankara

Bülent ALTEN, Hacettepe Üniv., Fen Fak., Ankara

Celal GÖKÇAY, ODTÜ, Çevre Müh., Ankara

Çağatay GÜLER, Hacettepe Üniv., Tıp Fak., Ankara

Daniel MOTLHANKA, Botswana College of Agriculture, Botswana
Delia Teresa SPONZA, Dokuz Eylül Üniv., Çevre Müh., İzmir

Diler ASLAN, Pamukkale Üniv., Tıp Fak., Denizli

Doğan YÜCEL, Ankara Eğ. E Arş. Hast., Ankara

Dürdal US, Hacettepe Üniv., Tıp Fak., Ankara

Dwight D. BOWMAN, Cornell Univ., College of Vet. Med., USA

Ender YARSAN, Ankara Üniv., Vet. Fak., Ankara

Fatih KÖKSAL, Çukurova Üniv., Tıp Fak., Adana

Gönül ŞAHIIN, Hacettepe Üniv., Eczacılık Fak., Ankara

Gülberk UÇAR, Hacettepe Üniv., Eczacılık Fak., Ankara

Gülnur TARHAN, Ahievran Üniv., Sağlık MYO, Kırşehir

Hakan LEBLEBiCiOĞLU, 19 Mayı Üniv., Tip Fak., Samsun

Haluk VAHABOĞLU, Kocaeli Üniv., Tıp Fak., Kocaeli

Hürrem BODUR, Numune Eğ. E Arş. Hast., Ankara

Işıl MARAL, Gazi Üniv., Tıp Fak., Ankara

Iva CHRISTOVA, NCIPD, Sofia, Bulgaria

İ.Mehmet Ali ÖKTEM, Dokuz Eylül Üniv., Tıp Fak., İzmir

İrfan EROL, Ankara Üniv., Vet. Fak., Ankara

İsmail CEYHAN, RSHMB, Ankara

Johan LINDH, Swedish Ins. for Infections Dis. Cont., Sweden

Kosta Y. MUMCUOĞLU, Hebrew Univ.,Hadassah Med. Sch. Israel 


\section{TÜRK HIJYYEN ve DENEYSEL BIYOLOJI DERGISI TURKISH BULLETIN OF HYGIENE AND EXPERIMENTAL BIOLOGY}

\section{BILIMSEL DANIŞMA KURULU / SCIENTIFIC ADVISORY BOARD}

Levent AKIN, Hacettepe Üniv., Tip Fak., Ankara

Mahinur AKKAYA, ODTÜ, Kimya Müh., Ankara

Manfred WEIDMANN, Göttingen Univ., Virology Ins., Germany

Mehmet Ali ONUR, Hacettepe Üniv. Fen Fak., Ankara

Metin KORKMAZ, Ege Üniv., Tıp Fak., İzmir

Mithat ŞAHIN, Kafkas Üniv., Vet. Fak., Kars

Murat DiZBAY, Gazi Üniv., Tıp Fak., Ankara

Murat GÜLMEZ, Kafkas Üniv., Vet. Fak., Kars

Murat GÜNAYDIN, 19 Mayıs Üniv., Tıp Fak., Samsun

Murat HÖKELEK, 19 Mayıs Üniv., Tıp Fak., Samsun

Murat ÖZSAN, Ankara Üniv., Tıp Fak., Ankara

Mustafa KAVUTÇU, Gazi Üniv., Tıp Fak., Ankara

Mükerrem KAYA, Atatürk Üniv., Ziraat Fak., Erzurum

Nazmi ÖZER, Hacettepe Üniv., Tıp Fak., Ankara

Nilay ÇÖPLÜ, RSHMB, Ankara

Nur Münevver PINAR, Ankara Üniv., Fen Fak., Ankara

Oğuz GÜRSOY, Pamukkale Üniv., Gıda Müh., Denizli

Orhan BAYLAN, GATA, Ankara

Orhan YILMAZ, KBB, Dışkapı Eğ. E Arş. Hast., Ankara

Osman GÜNAY, Erciyes Üniv., Tıp Fak., Kayseri

Paul HEYMAN, Queen Astrid Military Hospital, Belgium
Pauline MWINZI, Medical Research Inst., Kenya

Pınar OKYAY, Adnan Menderes Üniv., Tıp Fak., Aydın

Rahmet ÇAYLAN, Atatürk Eğ. E Arş. Hast., Ankara

Recep AKDUR, Ankara Üniv., Tıp Fak., Ankara

Recep ÖZTÜRK, İstanbul Üniv., Cerrahpaşa Tıp Fak., İstanbul

Rıza DURMAZ, İnönü Üniv., Tıp Fak., Malatya

Roberto Canete VILLAFRANCA, Centre for Hygiene, Cuba

S. Aykut AYTAÇ, Hacettepe Üniv. Gıda Müh., Ankara

Sami AYDOĞAN, Erciyes Üniv., Tıp Fak., Kayseri

Sema BURGAZ, Gazi Üniv., Eczacilık Fak., Ankara

Sercan ULUSOY, Ege Üniv., Tıp Fak., İzmir

Sıraç DíLBER, Karolinska Univ., Medical School, Sweden

Suzan ÖZTÜRK-YILMAZ, Sakarya Üniv., Müh. Fak., Sakarya

Süheyla SÜRÜCÜOĞLU, Celal Bayar Üniv., Tıp Fak., Manisa

Takashi AKAMATSU, Prof. Emeritus, Japan

Tevfik PINAR, Kırıkkale Üniv., Tıp Fak., Kırıkale

Yesim ÖZBAŞ, Hacettepe Üniv. Gıda Müh., Ankara

Yeşim ÇETINKAYA-ŞARDAN, Hacettepe Üniv., Tıp Fak., Ankara

Yeşim TUNÇOK, Dokuz Eylül Üniv., Tıp Fak., İzmir

Zafer KARAER, Ankara Üniv., Vet. Fak., Ankara 


\section{TÜRK HIIJYEN VE DENEYSEL BIYYOLOJI DERGISI YAZIM KURALLARI}

Dergide yayınlanmak üzere gönderilen makaleler, Türk Hijyen ve Deneysel Biyoloji Dergisi yazım kurallarına göre hazırlanmalıdır. Bașvurular www. turkhijyen.org adresinden “Çevrimiçi Makale Gönder, Takip Et, Değerlendir Programı” aracılığıyla online olarak yapılabilir.

Gönderilen yazılarda așağıdaki kurallar aranır:

1- "Telif hakkı devir formu" (Copyright Release Form) tüm yazarlarca imzalanarak onaylandıktan sonra Dergimize iletilmelidir. Bu forma www.turkhijyen.org adresinden ulașilabilinir.

2- Başlık sayfasında makale bașlığı, İngilizce bașlık, kısa bașlık, yazar adları, çalıșılan kurumlara ait birimler, yazıșma ișini üstlenen yazarın açık adresi, telefon numaraları (sabit ve cep), elektronik posta adresi belirtilmelidir:

a) Yazının bașlığı kısa olmalı ve büyük harfle yazıımalıdır.

b) Sayfa bașlarına konan kısa bașlık 40 karakteri geçmemelidir.

c) Akademik unvan kullanılmadan meslek unvanı belirtilebilir.

d) Makale birden fazla yazar tarafından yazılmıș ise, aynı ünitede çalıșan yazarların kurumlarının sıralaması göz önünde bulundurularak soyadları sonuna numara verilmelidir (Örnek; Duman 1, Yılmaz 2, Cetin 1, .....).

e) Çalıșma bilimsel bir kuruluș ve/veya fon ile desteklenmișse dipnot veya teșekkür bölümünde mutlaka belirtilmelidir.

f) Makale, kongre/sempozyumda sunulmussa sunum türü ile birlikte dipnot veya teșekkür bölümünde mutlaka belirtilmelidir.

3- Yazılardaki terimler mümkün olduğunca Türkçe ve Latince olmalı, dilimize yerleșmiș kelimelere yer verilmeli ve Türk Dil Kurumu'nun güncel sözlüğü kullanılmalıdır. Öz Türkçe'ye özen gösterilmeli ve Türkçe kaynak kullanımına önem verilmelidir.

4- Metin içinde geçen Latince mikroorganizma isimleri ilk kullanıldığında tam ve açı yazılmalı, daha sonraki kullanımda kısaltılarak verilmelidir. Mikroorganizmaların orijinal Latince isimleri italik yazılmalıdır: Örneğin; Pseudomonas aeruginosa, $P$. aeruginosa gibi. Yazıda sadece cins adı geçen cümlelerde stafilokok, streptokok gibi dilimize yerleșmis cins adları Türkçe olarak yazılabilir. Antibiyotik isimleri dil bütünlüğü açısından okunduğu gibi yazılmalıdır. Antibiyotik isimleri uluslararası standartlara uygun olarak kısaltılmalıdır.

5- Metin içerisinde bahsedilen birimlerin sembolleri "The Système International” (SI)'e göre verilmelidir.

6- Yazılar bir zorunluluk olmadıkça "miș'li geçmiș" zaman edilgen kip ile yazılmalıdır.

7- A4 kağıtların yalnız bir yüzü kullanılmalı, her bir kenarlarından 2,5'ar cm boșluk bırakılmalıdır. 12 punto, "Times New Roman” yazı karakteri ve iki satır aralığı (double space) kullanılmalıdır.

8- Türk Hijyen ve Deneysel Biyoloji Dergisi, yazarlardan araștırma ve yayın etiğine uyumlu olunmasını istemektedir. İnsan araștırmalarında, çalıșmaya katılanlardan bilgilendirilmis olurun (yazılı veya sözlü) alındığının gerec ve yöntem bölümünde belirtilmesi gerekmektedir. Gönüllü ya da hastalara uygulanacak prosedürlerin özelliği tümüyle anlatıldıktan sonra, kendilerinin bilgilendirilip onaylarının alındığını gösterir bir cümle bulunmalıdır. Yerel etik kurullarına sahip olmayan yazarlar, Helsinki Bildirgesinde (www.wma.net/e/ policy/pdf/17c.pdf) ana hatlarını çizilen ilkeleri izlemelidirler. Yazarlar, bu tür bir calıșma söz konusu olduğunda, uluslararası alanda kabul edilen kılavuzlara ve "ílaç Araștırmaları Hakkında Yönetmelik" ve daha sonra yayınlanan diğer yönetmelik ve yazılarda belirtilen hükümlere uyulduğunu belirtmeli ve kurumdan aldıkları "Etik Kurul Onayı"nı göndermelidirler.

9- Hayvanlar üzerinde yapılan çalıșmalar için de gereken izinler alınmalı; yazıda deneklere ağrı, acı ve rahatsızlık verilmemesi için neler yapıldığı açık bir șekilde belirtilmelidir.

10- Hasta kimliğini tanıtacak fotoğraf kullanıldığında, hastanın yazılı onayı gönderilmelidir.

11- Makale yazımında dikkat edilecek hususlar șunlardır:

a) Araștırma yazıları; Türkçe Özet, İngilizce Özet, Giriș, Gereç ve Yöntem, Bulgular, Tartıșma ve Kaynaklar bölümlerinden olușmalıdır. Bu bölümler, sola yaslanacak șekilde büyük harflerle kalın yazılmalıdır. İngilizce makalelerde Türkçe Bașlık ve Özet bulunmalıdır.

Türkçe Özet: Amaç, Yöntem, Bulgular ve Sonuç alt bașlıklarından olușmalıdır (yapılandırılmıs özet) ve en az 250, en fazla 400 sözcük içermelidir. Kısa raporlarda sözcük sayısı en az 100, en fazla 200 olmalıdır.

İngilizce Özet (Abstract): Bașlığı İngilizce olmalıdır. Türkçe Özet bölümünde belirtilenleri birebir karșılayacak șekilde "Objective, Method, Results, Conclusion" olarak yapılandırılmalıdır.

Anahtar Sözcükler: Türkçe ve İngilizce özetlerin altında verilmelidir. Anahtar kelime sayısı 3-8 arasında olmalı ve Tıp Konuları Bașlıkları (Index Medicus Medical Subject Headings-MeSH)'nda yer alan sözcükler kullanılmalıdır. MeSH için șu internet adresine bașvurulabilir: www.nlm.nih.gov/mesh MBrowser.html Giriș: Araștırmanın amacı, benzer çalıșmalarla ilgili literatür bilgisi kısaca sunulmalı ve iki sayfayı așmamalıdır.

\section{Türk Hijyen ve Deneysel Biyoloji Dergis}

Türkiye Halk Sağlığı Kurumu

Tel : (0312) 4582364
Gereç ve Yöntem: Araștırmanın gerçeklestirildiği kurulus ve tarih belirtilmeli, araștırmada kullanılan araç, gereç ve yöntem açıkça sunulmalıdır. İstatistiksel yöntemler açıkça belirtilmelidir.

Bulgular: Sadece elde edilen bulgular açık bir șekilde belirtilmelidir.

Tartıșma: Bu bölümde, araștırmanın sonunda elde edilen bulgular, diğer araștırıcıların bulgularıyla karșılaștırılmalıdır. Araștırıcı, kendi yorumlarını bu bölümde aktarmalıdır.

Teșekkür Bölümü: Teșekkür bölümü, ana metnin sonunda kaynaklardan hemen önce yer almalı ve bir paragrafı geçmemelidir.

Kaynaklar: Yazarlar kaynakların eksiksiz ve doğru yazılmasından sorumludur Kaynaklar, metnin içinde geçiș sırasına göre numaralandırılmalıdır. Numaralar, parantez içinde cümle sonlarında verilmelidir. Kaynakların yazılımı ile ilgil așağıda örnekler verilmistir. Daha detaylı bilgi için "Uniform Requirements for Manuscripts submitted to Biomedical Journals" (J Am Med Assoc 1997; 277: 927 934) (http://www.nejm.org/general/text/requirements/1.htm) bakılmalıdır. Süreli yayın: Yazar(lar)ın Soyadı Adının baș harf(ler)i (altı veya daha az yazar varsa hepsi yazılmalıdır; yazar sayısı yedi veya daha çoksa yalnız ilk altısın yazıp "et al." veya "ve ark." eklenmelidir). Makalenin baslığı, Derginin Index Medicus'a uygun kısaltılmıș ismi, Yıl; Cilt (Sayı): İlk ve son sayfa numarası.

- Standart dergi makalesi için örnek: Demirci M, Ünlü $M$, Sahin Ü. A case of hydatid lung cyst diagnosed by kinyoun staining of bronco-alveolar fluid. Turkiye Parazitol Derg, 2001; 25 (3): 234-5.

- Yazarı verilmemis makale için örnek: Anonymous. Coffee drinking and cancer of the panceras (Editorial). Br Med J, 1981; 283:628.

- Dergi eki için örnek: Frumin AM, Nussbaum J, Esposito M. Functinal asplenia: Demonstration of splenic activity by bone marrow scan (Abstract). Blood, 1979, 54 (Suppl 1): 26a.

Kitap: Yazar(lar)ın soyadı adının baș harf(ler)i. Kitabın adı. Kaçıncı bask olduğu. Basım yeri: Yayınevi, Basım yılı.

- Örnek: Eisen HN. Immunology: an Introduction to Molecular and Cellular Principles of the Immun Response. 5th ed. New York: Harper and Row, 1974. Kitap bölümü: Bölüm yazar(lar)ın soyadı adının bașharf(ler)i. Bölüm bașlığı. In: Editör(ler)in soyadı adının bașharf(ler)i ed/eds. Kitabın adı. Kaçıncı bask olduğu. Basım yeri: Yayınevi, Basım yılı: Bölümün ilk ve son sayfa numarası.

- Örnek: Weinstein L. Swarts MN. Pathogenic properties of invading microorganisms. In: Sodeman WA Jr, Sodeman WA, eds. Pathologic Physiol ogy: Mechanism of Disease. Phidelphia. WB Saunders, 1974:457-72.

Web adresi: Eğer doğrudan "web” adresi referans olarak kullanılacaksa adres ile birlikte parantez icinde bilgiye ulașilan tarih de belirtilmelidir. Web erisimli makalelerin referans olarak metin içinde verilmesi gerektiğinde DOI (Digital Object Identifier) numarası verilmeși șarttır.

Kongre bildirisi: Entrala E, Mascaro C. New stuructural findings in Cryptosporidium parvum oocysts. Eighth International Congress of Parasitology (ICOPA VIII). October,10-14, Izmir-Turkey. 1994.

Tez: Bilhan Ö. Labirent savakların hidrolik karakteristiklerinin deneysel olarak incelenmesi. Yüksek Lisans Tezi, Fırat Üniversitesi Fen Bilimleri Enstitüsü, 2005 GenBank/DNA dizi analizi: Gen kalıtım numaraları ve DNA dizileri makale içinde kaynak olarak gösterilmelidir. Konuyla ilgili ayrıntılı bilgi için "National Library of Medicine" adresinde "National Center for Biotechnical Information (NCBI)" bölümüne bakınız.

Şekil ve Tablolar: Her tablo veya șekil ayrı bir sayfaya basılmalı, alt ve üst cizgiler ve gerektiğinde ara sütun cizgileri içermelidir. Tablolar, "Tablo 1 șeklinde numaralandırılmalı ve tablo bașlığı tablo üst çizgisinin üstüne yazılmalıdır. Açıklayıcı bilgiye bașlıkta değil dipnotta yer verilmeli, uygun simgeler $\left({ }^{*},+,++\right.$, v.b.) kullanılmalıdır. Fotoğraflar "jpeg" formatında ve en az 300 dpi olmalıdır. Baskı kalitesinin artırılması için gerekli olduğu durumlarda fotoğrafların orijinal halleri talep edilebilir.

b) Derleme türü yazılarda; tercihen yazar sayısı ikiden fazla olmamalıdır. Yazar(lar) daha önce bu konuda çalıșma ve yayın yapmıș olmalı; bu deneyimlerini derleme yazısında tartısmalı ve kaynak olarak göstermelidir Derlemelerde Türkce ve İngilizce olarak baslık, özet (en az 250, en fazla 400 sözcük içermelidir) ve anahtar sözcükler bulunmalıdır.

c) Olgu sunumlarında; metin yedi sayfayı, kaynak sayısı 20'yi asmamalıdır. Türkçe ve İngilizce olarak başlık, özet (en az 100, en fazla 200 sözcük) ve anahtar sözcükler ayrıca giris, olgu ve tartıșma bölümleri bulunmalıdır.

d) Daha önce yayımlanmıș yazılara eleștiri getirmek, katkıda bulunmak ya da bilim haberi niteliği tașıyacak bilgilerin iletilmesi amacıyla yazılan yazılar Yayın Kurulu'nun inceleme ve değerlendirmesinin ardından "Editöre Mektup" bölümünde yayınlanır. Bu yazıların bir sayfayı așmaması ve en fazla beș kaynakla desteklenmesi gerekmektedir.

12- Bu kurallara uygun olmayan metinler kabul edilmez.

13- Yazarlar teslim ettikleri yazının bir kopyasını saklamalıdır. 


\section{WRITING RULES OF TURKISH BULLETIN OF HYGIENE AND EXPERIMENTAL BIOLOGY}

Articles should be prepared according to the writing rules of the Turkish Bulletin of Hygiene and Experimental Biology. Submissions can be made online at the address www.turkhijyen.org through the "Online Manuscript Submission, Track, Evaluation Program".

Manuscripts are sought according to the following rules:

1- The "Copyright transfer form" (Copyright Release Form) should be sent to the Journal and signed by all authors. This form can be downloaded from www.turkhijyen.org

2- The title page should consist of the article title, English title, short title, author name(s), names of the institutions and the departments of the authors, full address, telephone numbers (fixed and mobile) and mail address of the correspondence author:

a) The title should be short and in capital.

b) The short title should not exceed 40 characters.

c) Occupational titles can be stated without the use of academic titles.

d) If the article is written by multiple authors and the authors working in the same Department, than according to their institutional orders, numbers should be given after their surname (e.g., Duman1, Yılmaz2, Çetin1, .....).

e) Studies supported by a fund or organisation must be mentioned in a footnote or in the acknowledgements.

f) Articles presented in a conference / symposia must be mentioned with the type of presentation in footnotes or in the acknowledgements.

3- Terms used in articles should be in Turkish and Latin as much as possible, according to the latest dictionary of the "Turkish Language Institution". Importance should be given to use pure Turkish language and as many as Turkish references.

4- Latin names of microorganisms used for the first time in the text have to be written in full. If these names are used later, they should be abbreviated in accordance to international rules. The original Latin names of microorganisms should be written in Italic: for example, Pseudomonas aeruginosa, $P$. aeruginosa. Genus names like staphylococcus and streptococcus that had settled into our language can be written in Turkish. Names of antibiotics should be written as they are read in terms of language integrity. Names of antibiotics should be abbreviated in accordance with international standards.

5- Symbols of the units mentioned in the text should be according to "The Système International (SI).

6- Articles should be written in one of the "past perfect, present perfect and past" tenses and in the passive mode.

7- Only one side of A4 paper should be used and should have a $2.5 \mathrm{~cm}$ margin on each side. 12 pt, Times New Roman font and double line space should be used. 8- The Turkish Journal of Hygiene and Experimental Biology expects the authors to comply with the ethics of research and publication. In human research, a statement of the informed consent of those who participated in the study is needed in the section of the "Materials and method. In case of procedures that will apply to volunteers or patients, it should be stated that the study objects have been informed and given their approval before the study started. In case the authors do not have a local ethics committee, the principles outlined in the Declaration of Helsinki should have been followed. Authors, who do not have a local ethics committee, should declare that they have followed

the internationally accepted guidelines, the "Pharmaceutical Research and Regulation" legislation and other related regulations.

9- In case animal studies, approval also is needed; it should be stated clearly that the subjects will be prevented as much as possible from pain, suffering and inconvenience.

10- In case patient photos are used which shows his/her ID, a written informed consent of the patient on the use of the photos must be submitted.

11- When writing an article the following items should be considered:

a) Research papers should consist of Turkish abstract, English abstract, Introduction, Materials and Methods, Results, Discussion and References section. These sections should be written in bold capital letters and aligned left. English articles should have a Turkish abstract and title in Turkish.

Turkish abstracts should be structured and consist of subheadings (Objective, Methods, Results and Conclusion) and at least have 300 words, and should contain no more than 500 words.

English abstract: The title should be in English, and structured like the Turkish abstract (Objective, Methods, Results, and Conclusion).

Key words should be given under Turkish and English.

The number of keywords should be between 3-8 and the terminology of the Medical Subjects Headings (Index Medicus Medical Subject Headings-MeSH) should be used. These MeSH terms can be found at the following Internet address: http: //www.nlm.nih.gov/mesh/MBrowser.html

Introduction: The aim of the study, and references given to similar studies should be presented briefly and should not exceed more than two pages.
Materials and Methods: The date of the study and institution that performed the study, and materials and methods should be clearly presented. Statistical methods should be clearly stated.

Results: The findings should be stated clearly.

Conclusions: In this section, the study findings should be compared with findings of other researchers. Investigators should mention their comments in this section.

Acknowledgements should be placed at the end of the main text and before the references, and should not exceed more than one paragraph.

References: Authors are responsible for supply complete and correct references. References should be numbered according to the order used in the text. Numbers should be given in brackets and placed at the end of the sentence. Examples are given below on the use of references. Detailed information can be found in "Uniform Requirements for Manuscripts Submitted to Biomedical Journals" (J Am Med Assoc 1997 277: 927-934) and at http:// www.nejm.org/general/text/requirements/1.htm

Periodicals: Author(s) Last Name initial(s) name of author(s) (if there are six or fewer authors, all authors should be written; if the number of authors are seven or more, only the first six of the authors should be written and the rest as "et al"). The title of the article, the abbreviated name of the journal according to the Index Medicus, Year; Volume (Issue): The first and last page numbers.

- Example of standard journal article: Demirci M, Celebrity M, Sahin U. A case of hydatid cyst diagnosed by kinyoun staining of lung bronco-alveolar fluid. Türkiye Parazitol Derg, 2001; 25 (3): 234-5.

- Example of an article with authors unknown: Anonymous. Coffee drinking and cancer of the pancreas (Editorial). Br Med J, 1981; 283:628.

- Example of journal supplement: Frumin AM, Nussbaum J, Esposito M Functional asplenia: Demonstration of splenic activity by bone marrow scan (Abstract). Blood, 1979; 54 (Suppl 1): 26a.

Books: Surname of the author(s) initial name(s) of author(s). The name of the book. The edition number. Place of publication: Publisher, Publication year.

- Example: Eisen HN. Immunology: an Introduction to the Principles of Molecular and Cellular Immune Response. 5th ed. New York: Harper and Row, 1974.

Book chapters: The author(s) surname of the chapter initial(s) letter of the name. Section title. In: Surname of editor(s) initial (s) letter of first name(s) ed / eds. The name of the book. Edition number. Place of publication: Publisher, year of publication: The first and last page numbers of the chapter.

- Example: Weinstein L. Swarts MN. Pathogenic properties of invading microorganisms. In: Sodeman WA Jr, Sodeman WA, eds. Pathologic Physiology: Mechanism of Disease. Phidelphia. WB Saunders, 1974:457-72.

Web address: If a "web" address is used as the reference address, the web address date should be given in brackets with the address. The DOI (Digital Object Identifier) number must be provided, when a web access article used in the text as a reference.

Congress papers: Entrala E, Mascaro C. New structural findings in Cryptosporidium parvum oocysts. Eighth International Congress of Parasitology (ICOPA VIII). October, 10-14, Izmir-Turkey. 1994.

Thesis: Bilhan Ö. Experimental investigation of the hydraulic characteristics of labyrinth weir. Master Thesis, Science Institute of Firat University, 2005.

GenBank / DNA sequence analysis: DNA sequences of genes and heredity numbers should be given as references in the article. For more information, check "National Library of Medicine" and "National Center for Biotechnical Information (NCBI)".

Figure and Tables: Each table or figure should be printed on a separate sheet, the top and bottom lines and if necessary column lines must be included. Tables should be numbered like "Table 1." and the table title should be written above the top line of the table. Explanatory information should be given in footnotes, not in the title and appropriate icons $\left({ }^{*},+,++\right.$, etc.) should be used. Photos should be in "jpeg" format. In case the quality of the photos is not good for publication, the originals can be requested.

b) In reviews, it is preferred to have not more than two authors. Author(s) must have done research and published articles previously on this subject; they should discuss their experience and use as reference in the review. Reviews should have Turkish and English titles, abstracts and key words.

c) Case reports should have a maximum of seven pages of text and the number of references should not exceed 20. Case report should have a Turkish and English title, abstract, keyword(s) and also introduction, case description and discussion sections should be given.

d) Letters written to make criticisms, contributions or to give news related to previously published articles will be published in the "Letters to the Editor" section after review and assessment of the Editorial Board. Letters should not exceed one page of text and must be supported with up to five references.

12- The articles which do not comply with the journal rules are not accepted. 13- Authors should keep a copy of the article that they submit. 


\section{TÜRK HIJYEN VE DENEYSEL BIYOLOJI DERGISI}

\section{YAYIN İLKELERI}

- Türk Hijyen ve Deneysel Biyoloji Dergisi, Refik Saydam Hıfzıssıhha Merkezi Başkanlığı yayın organıdır. Dergi üç (3) ayda bir çıkar ve dört (4) sayıda bir cilt tamamlanır.

- Dergide mikrobiyoloji, immünoloji, farmakoloji, toksikoloji, parazitoloji, entomoloji, biyokimya, gıda güvenliği, çevre sağlığı, halk sağlığı, epidemiyoloji, patoloji, fizyopatoloji, molekuler biyoloji ve genetik ile ilgili alanlardaki özgün araştırma, olgu sunumu, derleme, editöre mektup türündeki makaleler Türkçe ve İngilizce olarak yayımlanır.

- Dergide, daha önce başka yerde yayınlanmamış ve yayınlanmak üzere başka bir dergide inceleme aşamasında olmayan makaleler yayımlanır.
- Dergi Yayın Kurulu ve Bilimsel Danışma Kurulu tarafından uygun görülen yazılar, konu ile ilgili en az iki Bilimsel Danışma Kurulu Üyesinden olumlu görüşü alındığında yayımlanmaya hak kazanır. Bu kurulların, yazının içeriğini değiştirmeyen her türlü düzeltme ve kısaltmaları yapma yetkileri vardır.

- Yazıların bilimsel ve hukuki sorumluluğu yazarlarına aittir.

- Yazarlar araştırma ve yayın etiğine tam olarak uyum göstermelidir.

- Dergide yayınlanan yazıların yayın hakkı Türk Hijyen ve Deneysel Biyoloji Dergisine aittir. Yazarlara telif ücreti ödenmez.

YAZAR(LAR) IÇINN MAKALE KONTROL LISTESI

- Bütün yazarlarca isim sırasına göre imzalanmış telif hakkı devir formu eksiksiz olarak dolduruldu.

- Yazar isimleri açık olarak yazıldı.

- Her yazarın bağlı bulunduğu kurum adı, yazar adının yanına numara verilerek başlık sayfasında belirtildi.

- Yazışmalardan sorumlu yazarın adi, adresi, telefon-faks numaraları ve e-posta adresi verildi.

- Türkçe ve İngilizce başlıklar ile kısa başlık yazıldı.

- Türkçe ve İngilizce özetlerin kelime sayısı (300-500 arası) kontrol edildi.

- Türkçe ve İngilizce anahtar kelimeler (MeSH'e uygun) verildi.

- Tüm kısaltmalar gözden geçirildi ve standart olmayan kısaltmalar düzeltildi.

- Metin içerisinde geçen orijinal Latince mikroorganizma isimleri italik olarak yazıldı.

- Metin içerisinde bahsedilen birimlerin sembolleri the Système International (SI)'e göre verildi.

- Yazılar "miş'li geçmiş" zaman edilgen kip ile yazıldı.
- Metnin tamamı 12 punto Times New Roman karakteri ile çift aralıkla yazıldı.

- Metin sayfanın yalnız bir yüzüne yazılarak her bir kenardan $2,5 \mathrm{~cm}$ boşluk bırakıld.

- Tablolar, şekiller yazım kurallarına uygun olarak ve her biri ayrı bir sayfada verildi.

- Fotoğraflar JPEG formatında aktarıldı.

- Kaynaklar cümle sonlarında parantez içinde ve metin içinde kullanım sırasına göre ardışık sıralandı.

- Kaynaklar, makale sonunda metin içinde verildiği sırada listelendi.

- Kaynaklar gözden geçirildi ve tüm yazar adları, ifade ve noktalamalar yazım kurallarına uygun hale getirildi.

Ayrıca aşağıda belirtilen maddeleri dikkate alınız.

- Etik kurul onayı alındı.

- Bilimsel kuruluş ve/veya fon desteği belirtildi.

- Kongre/Sempozyumda sunumu ve sunum türü belirtildi.

- Varsa teşekkür bölümü oluşturuldu. 


\section{EDITORIAL POLICY}

- The Turkish Journal of Hygiene and Experimental Biology, is a publication of the Refik Saydam National Public Health Agency. The Journal is published every other three months and one volume consist of four numbers.

- The journal publishes microbiology, immunology, pharmacology, toxicology, parasitology, entomology, biochemistry, food safety, environmental health, public health, epidemiology, pathology, pathophysiology, molecular biology and genetics in the field of original research, case reports, reviews, and letters to the editor. Articles are published in Turkish and English.

- Articles which are not previously published in another journal or are not currently under evaluation elsewhere can be published in the journal.
- Articles approved by the Scientific Committee and Editorial Board are eligible to be released when received at least two positive opinions from the Scientific Committee members. Those committees have the authority to make all corrections and abbreviations but not to change the content of the article.

- The authors have the all the scientific and legal responsibilities of the articles.

- The authors should obey the ethics of research and publication.

- The copyright of the article published in the Bulletin of Experimental Hygiene belongs to the Journal. Copyright fee is not paid to the authors.

\section{CHECKLIST OF THE ARTICLE FOR AUTHOR(S)}

- Copyright transfer form is completed in full and signed by all authors according to the name order.

- Author names are written clearly.

- Affiliated institutions of the all authors are given on the title page by the number stated after the author's name.

- The name, address, phone-fax numbers and mail address of the author responsible for correspondence are given.

- Turkish, English titles and short title are written.

- The number of words in Turkish and English abstracts (between $300-500)$ is checked.

- Turkish and English keywords (according to MeSH) are given.

- All abbreviations are reviewed and non-standard abbreviations are corrected

- Original Latin names of microorganisms are written in italic.

- Symbols are mentioned according to the units in the Système International (SI).

- The article is written in passive mode and given one of the "past perfect, present perfect or past " tenses.

- Text is written in 12 pt Times New Roman characters and with double line spacing.
- Text is written only on one side of the page and has $2.5 \mathrm{~cm}$ space at each side.

- Tables and figures are given on each separate page according to the writing rules.

- Photos are in JPEG format.

- References are given at the end of the sentence in brackets and are listed in order of use in the text.

- References are listed at the end of the article in the order given in the text.

- References are reviewed, and the name of all authors, spelling and punctuation are controlled according the writing rules.

Furthermore, please check.

- "Ethics Committee Approval" is given.

- Support to a study by a fund or organization is mentioned.

- Congress / Symposium presentations and the type of presentation are stated.

- Acknowledgement is given, if there is. 
Türk Hijyen ve Deneysel Biyoloji Dergisi'ne www.turkhijyen.org adresinden online olarak makale gönderilebilir.

Submissions can be made online at the address www.turkhijyen.org to Turkish Bulletin of Hygiene and Experimental Biology.

\begin{tabular}{|c|c|}
\hline \multicolumn{2}{|l|}{ CABI Index } \\
\hline $\begin{array}{r}\text { Chemical Abstracts } \\
\text { Service (CAS) }\end{array}$ & 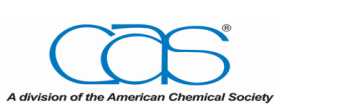 \\
\hline \multicolumn{2}{|l|}{ DOAJ } \\
\hline Index Copernicus & INDEX COPERNICUS \\
\hline Google Scholar & Oogle \\
\hline \multicolumn{2}{|l|}{ Open J-Gate } \\
\hline $\begin{array}{r}\text { Academic } \\
\text { Journals Database }\end{array}$ & 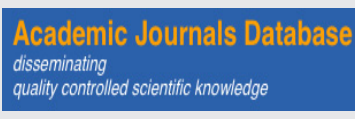 \\
\hline $\begin{array}{r}\text { Scirus } \\
\text { Scientific Database }\end{array}$ & $\underset{\text { for scientific information only }}{\text { SCIVSS }}$ \\
\hline Libsearch & \&libsearch \\
\hline
\end{tabular}

Türk Hijyen ve Deneysel Biyoloji Dergisi;

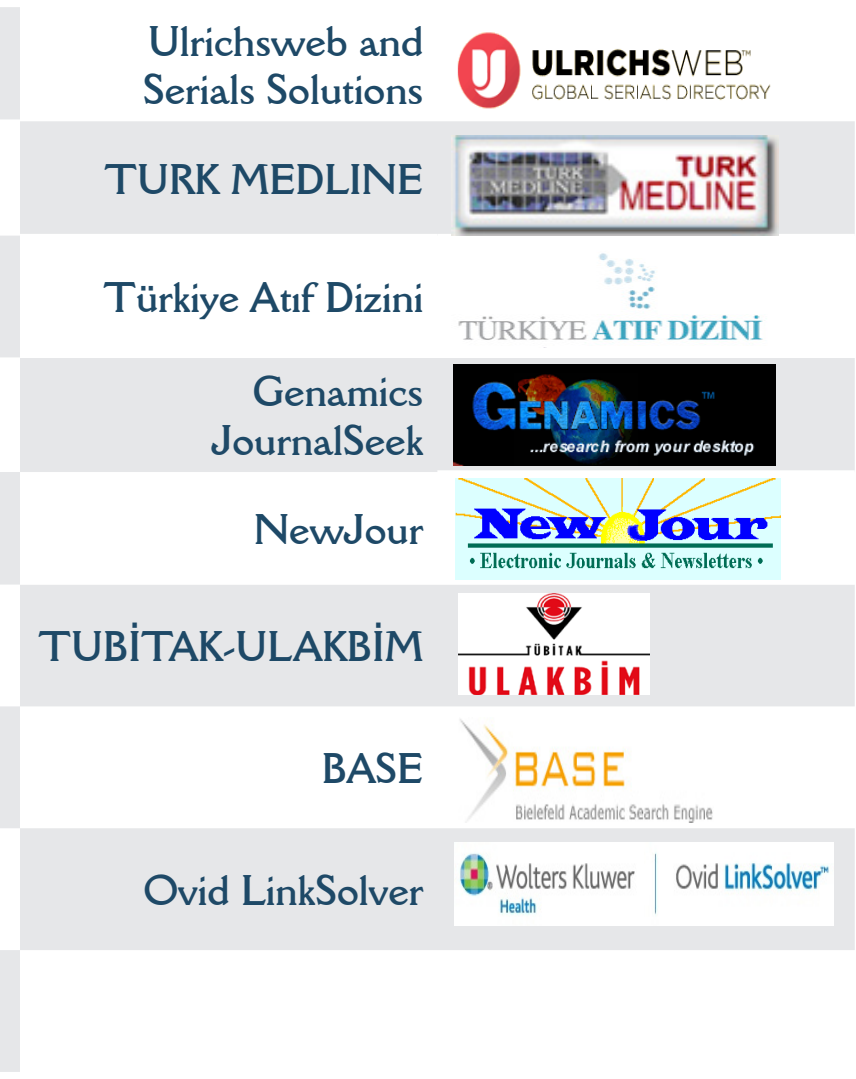

tarafindan dizinlenmektedir.

The Turkish Bulletin of Hygiene and Experimental Biology (Turk Hij Den Biyol Derg) is indexed in CAB Abstracts, Index Copernicus, Google Scholar, DOAJ (Directory of Open Access Journals), Open J-Gate, CAS (Chemical Abstracts Service), Ulrichsweb and Serials Solutions, NewJour, Genamics JournalSeek, Academic Journals Database, Scirus Scientific Database, Libsearch, BASE, Ovid LinkSolver, TUBITAK-ULAKBIM, TURKIYE ATIF DIZINI and TURK-MEDLINE.

\begin{tabular}{|c|c|}
\hline İ L E T İ Ş İ M & CORRESPONDENCE \\
\hline Türkiye Halk Sağlığı Kurumu & Public Health Institution of Turkey \\
\hline Türk Hijyen ve Deneysel Biyoloji Dergisi & Turkish Bulletin of Hygiene and Experimental Biology \\
\hline $\begin{array}{l}\text { Sağlik Mah. Adnan Saygun Cad. Nu: } 5506100 \text { Sihhiye/ANKARA } \\
\text { Tel: } 03124582364 \quad \text { http: www.rshm.gov.tr } \\
\text { Faks: } 03124582408 \quad \text { e-posta: turkhijyen@rshm.gov.tr }\end{array}$ & $\begin{array}{l}\text { SaglikMah. Adnan Saygun Cad. No: } 5506100 \text { Sihhiye/ANKARATURKEY } \\
\text { Tel: +9003124582364 http: www.rshm.gov.tr } \\
\begin{array}{ll}\text { Fax: +9003124582408 e-mail: turkhijyen@rshm.gov.tr }\end{array}\end{array}$ \\
\hline www.turkhijyen.org & www.turkhijyen.org \\
\hline
\end{tabular}





\section{IÇiNDEKILER}

\section{Araștırma Makalesi}

1. Türkiye'de 2007 - 2008 influenza sezonunda oseltamivir dirençli influenza A (H1N1) virüslerinin $\mathrm{H} 274 \mathrm{Y}$ mutasyonu ile saptanması

Ahmet ÇARHAN, Nurhan ALBAYRAK, Ayșe Başak ALTAȘ, Yavuz UYAR, Etem ÖZKAYA

2. Diyaliz sularının mikrobiyal kontaminasyon ve bakteriyel endotoksin testleri ile kontrolü

Fesem BAŞARI, Öznur UYANIK

3. İstanbul'da hayat kadınları ile hastanemizin kadın hastalıkları ve doğum kliniği hastalarındaki vajinal kandidiyazın görülme sıklığının 10 yıl önceki oranla kıyaslanması

Erdal POLAT, Serhat SIREKBASAN, Burcu AYDIN, Zehra YILDIRIM, Yaşar BAĞDATLI, İsmail ÇEPNi, Tayfur ÇiFT, Nezihe D. BALTALI

4. Kauçuk yapıda Foley idrar sondalarının sitotoksisitesinde çinko bileşiklerinin olası rolü

Mehmet Kürşat DERICi, Hakan BÜZKAYA, Ferat ȘAHIN

5. Konya ilinde köpeklerde listeriozis seroprevalansı

Zeki ARAS, Uçkun Sait UÇAN

\section{Olgu Sunumu}

6. S19 hayvan așısının kazayla inokülasyonu sonucu gelişmiş bir bruselloz olgusu

Ahmet KARAKAŞ, Gürkan MERT, Ömer ÇOŞKUN, Ömer Hilmi ALGA， Bülent Ahmet BEşiRBELLioĞLU, Can Polat EYigüN

\section{Derleme}

7. Gıdalarda aflatoksin varlığının değerlendirilmesi 


\section{CONTENTS}

\section{Original Article}

1. Detection of oseltamivir-resistant influenza $A$ (H1N1) viruses with $\mathrm{H} 274 \mathrm{Y}$ mutation during the 2007 - 2008 influenza season in Turkey

Ahmet ÇARHAN, Nurhan ALBAYRAK, Ayșe Başak ALTAȘ, Yavuz UYAR, Etem ÖZKAYA

2. Control of dialysis water by microbial contamination and bacterial endotoxin tests

Fesem BAȘARI, Öznur UYANIK

3. Comparison of the incidence of vaginal candidiasis among prostitutes in Istanbul and patients of the Obstetrics and Gynecology Clinic of Cerrahpaşa Medical Faculty

Erdal POLAT, Serhat SIREKBASAN, Burcu AYDIN, Zehra YILDIRIM, Yașar BAĞDATLI, İsmail ÇEPNi, Tayfur ÇiFT, Nezihe D. BALTALI

4. The possible role of zinc compounds on the cytotoxicity of latex Foley urinary catheters

Mehmet Kürşat DERici, Hakan BÜZKAYA, Ferat ŞAHIN

5. The seroprevalence of canine listeriosis in dogs in Konya province

Zeki ARAS, Uçkun Sait UÇAN

\section{Case Report}

6. A case of human brucellosis associated with unintentional inoculation of the animal vaccine $\mathrm{S} 19$

Ahmet KARAKAȘ, Gürkan MERT, Ömer ÇOȘKUN, Ömer Hilmi ALGA, Bülent Ahmet BEȘíRBELLioĞLU, Can Polat EYiGÜN

\section{Review}

7. The evaluation of the aflatoxin presence in foods 


\title{
Türkiye'de 2007 - 2008 influenza sezonunda oseltamivir dirençli influenza $\mathrm{A}(\mathrm{H} 1 \mathrm{~N} 1)$ virüslerinin $\mathrm{H} 274 \mathrm{Y}$ mutasyonu ile saptanması
}

\author{
Detection of oseltamivir-resistant influenza A (H1N1) viruses with \\ H274Y mutation during the 2007 - 2008 influenza season in Turkey
}

Ahmet ÇARHAN ${ }^{1}$, Nurhan ALBAYRAK ${ }^{1}$, Ayşe Başak ALTAŞ ${ }^{1}, \quad$ Yavuz UYAR ${ }^{1}$, Etem ÖZKAYA ${ }^{1}$

\begin{abstract}
ÖZET
Amaç: Kuzey yarım kürede 2007-2008 influenza sezonunun başlangıcından itibaren dahaönce tanımlanmış olan influenza A (H1N1) virüsünün oseltamivir direncinin arttığısaptanmıștır. Bu direncin göstergesi, nöraminidaz (NA) geninin 274. aminoasidinin (H274Y) histidinden tirozine dönüşümü ile ortaya konmaktadır. Avrupa'da influenza A (H1N1) sușları arasında oseltamivire direnç oranı $\% 25$ olarak saptanmıştır. Bu oran ülkeler arasında farklılık göstermekle birlikte Norveç'te en yüksek (\%67), İspanya'da en düșük (\%2) olarak tespit edilmiștir. Bu çalışmada 2007-2008 influenza sezonunda Türkiye'deki influenza A H1N1 izolatlarında oseltamivir direncini tespit etmek amaçlanmıștır.
\end{abstract}

Yöntem: Refik Saydam Hıfzıssıhha Merkezi Bașkanlığı (RSHMB) Ulusal İnfluenza Merkezi'nde 2007 Kasım - 2008 Mayıs ayları arasında real-time RT-PCR ile test edilerek influenza A (H1N1) pozitif olarak bulunan toplam 73 örnek arasından rastlantısal olarak 20 örnek seçilmiştir. Oseltamivir direncini tespit etmek için influenza A H1N1 suşlarının NA gen bölgesi 274. aminoasitini hedefleyen RT-PCR ișlemi, histidinden tirozine dönüșümü göstermek

\section{ABSTRACT}

Objective: In the beginning of the 2007-2008 influenza season in Northern Hemisphere, the frequency of influenza A (H1N1) viruses bearing a previously defined oseltamivir resistance increased dramatically. This is conferring to the amino acid exchange from histidine to tyrosine at position 274 (H274Y) in neuraminidase (NA) gene. The overall frequency of oseltamivir resistance in influenza A (H1N1) strains in Europe was reported as being $25 \%$. Although it varied between countries, it was shown that the highest percentage was in Norway (67\%), and the lowest was in Spain (2\%). In this study, it was aimed to evaluate the oseltamivir resistance in influenza A H1N1 isolates from Turkey during the 20072008 influenza season.

Method: During November 2007 - May 2008, 20 samples were randomly selected between 73 influenza A (H1N1) positive samples detected with real-time RT- PCR in National Influenza Center (NIC) of Refik Saydam National Public Health Agency (RSNPHA). To detect such resistant viruses in Turkey, an RT-PCR assay was performed targeting amino acid position at 274 in NA gene of H1N1 influenza strain to investigate the presence or absence of histidine to tyrosine mutation.

' RSHMB, Salgın Hast. Arş., Müd. Viroloji Referans ve Araştırma Laboratuvarı, Ulusal Influenza Merkezi, Sıhhiye, ANKARA

İletişim/Corresponding Author: Nurhan ALBAYRAK

RSHMB, Salgın Hast. Arş., Müd. Vir. Ref. ve Arş. Lab., Ulusal Inf. Merk., Sıhhiye, ANKARA Geliş Tarihi / Received : 25.04 .2011

Tel : +903124582211_ E-posta / E-mail : nurhanalbayrak@hotmail.com Kabul Tarihi / Accepted : 15.02 .2012

DOI ID : 10.5505/TurkHijyen.2012.23600

Çarhan A, Albayrak N, Altaș AB, Uyar Y, Özkaya E. Türkiye'de 2007 - 2008 influenza sezonunda oseltamivir dirençli influenza A (H1N1) virüslerinin H274Y mutasyonu ile saptanması. Turk Hij Den Biyol Derg, 2012; 69(1): 1-6. 
için uygulanmıștır. İnfluenza virüslerinin NA geni sekanslanmıș ve daha önceden tanımlanmıș gen dizileri ile karșılaștırılarak direnç belirlenmiștir.

Bulgular: Çalıșmamızda değerlendirilen toplam 20 influenza A (H1N1) izolatının iki (\%10)'sinde oseltamivir direncinin göstergesi olan 274. (N1 numaralandırmasında 275) aminoasitte histidinden (H) tirozine (Y) değișim saptanmıștır. NA segmentinin kısmi dizi analizi sonuçları National Center for Biotechnology Information (NCBI) GenBankasında GQ369800, GQ369799, GQ369798 giriș numaraları ile sunulmuștur.

Sonuç: NA dizi analizi ile ülkemiz orta ve doğu kısımlarından gelen influenza A (H1N1) sușlarının $\mathrm{H} 274 \mathrm{Y}$ oseltamivir direncinin değerlendirilmesiyle Türkiye'de 2008 yılında nöraminidaz inhibitörlerine direncin görülmeye bașlandığını belirlenmiștir.

Anahtar Sözcuikler: İnfluenza A (H1N1), oseltamivir direnci, H274Y mutasyonu, Türkiye
The NA genes of influenza, viruses were sequenced. The presence of resistance was inferred by comparison with published sequences and known resistant mutations.

Results:In our study, the histidine $(\mathrm{H})$ to tyrosine (Y) substitution at position 274 (275 in N1 numbering) of the NA gene was evaluated. The change indicating resistance to oseltamivir was observed in two isolates of the total 20 influenza A (H1N1) strains (10\%). The partial sequence analysis results of NA segments were submitted to the National Center for Biotechnology Information (NCBI) GenBank with accession numbers GQ369800, GQ369799, GQ369798.

Conclusion: Resistance to neuraminidase inhibitors was determined by NA gene sequencing in the isolates of $\mathrm{A} / \mathrm{H} 1 \mathrm{~N} 1$ strains taken from central and eastern parts of Turkey by monitoring the presence of $\mathrm{H} 274 \mathrm{Y}$ oseltamivir-resistant in 2008.

Key Words: Influenza A (H1N1), oseltamivir resistance, H274Y mutation, Turkey

\section{INTRODUCTION}

The prevalence of oseltamivir-resistant influenza viruses $\mathrm{A}$ (H1N1) dramatically increased worldwide at the beginning of 2007-2008 influenza season in the northern hemisphere. Recent reports indicated that by early 2009 most influenza A (H1N1) strains were resistant to oseltamivir (a neuraminidase inhibitor). These were associated with a specific "histidine-totyrosine mutation" at position $274(\mathrm{H} 274 \mathrm{Y}$; $\mathrm{H} 275 \mathrm{Y}$ in N1 numbering system) in the neurominidase (NA) protein that confers high-level resistance to oseltamivir (15). An increased number of influenza A viruses (H1N1) with resistance to oseltamivir was first reported by World Health Organization (WHO, Norway) in January 2008 and high levels of oseltamivir resistance were determined among influenza A ( $\mathrm{H} 1 \mathrm{~N} 1)$ viruses in European countries and USA (4,6-8). WHO Global Influenza Surveillance Network (GISN) showed that $16 \%$ of community isolates $(0 \%-67 \%$ by country) of influenza A viruses (H1N1) were oseltamivir resistant in the 2007 - 2008 season. The overall frequency of oseltamivir resistance in influenza $A$ ( $\mathrm{H} 1 \mathrm{~N} 1)$ strains from Europe was approximately 25\%. The frequency of seasonal influenza A (H1N1) viruses resistance to oseltamivir varied between countries. The highest percentage was observed in Norway (67\%), followed by France (47\%), while increased levels of resistance to oseltamivir were detected worldwide $(2-6,8)$.

The aim of this study was to determine the resistance to oseltamivir (neuraminidase inhibitor) in some influenza $\mathrm{A} \mathrm{H} 1$ isolates obtained during the 2007-2008 influenza season in central and eastern parts of Turkey. In order to detect such histidine to tyrosine mutation in amino acid position 274 in NA gene, RT-PCR assay was performed. 


\section{MATERIAL and METHODS}

To detect the dominant circulating influenza virus types and the efficiency of seasonal vaccine, Turkish Ministry of Health established in 2005 the National Influenza Surveillance Program (NISP). Influenza surveillance is conducted as sentinel surveillance system by two centers within 14 provinces, Refik Saydam National Public Health Agency (RSNPHA) National Influenza Center (NIC) and Istanbul University Faculty of Medicine Virology Laboratory which are the members of international information networks. The RSNPHA NIC is responsible for nine provinces in the central and eastern parts of Turkey for Sentinel Influenza Surveillance Programme (Figure 1). The clinical specimens were collected from nine sentinel collaborators as part of routine national virologic influenza surveillance during November 2007 - May 2008 influenza season. From all parts of the country, influenza activity was measured monthly to determine the predominant strain circulating in Turkey.

In this study, total of 20 influenza viruses, confirmed as influenza $A(\mathrm{H} 1)$ by real-time reverse transcriptionPCR (RT-PCR), were selected from 73 influenza A (H1) positive specimens of 2007-2008 influenza season. The specimens that contain high titer of the viruses were selected in order to work sequencing.
The NA genes of influenza viruses were sequenced and resistance was evaluated by comparison sequence of obtained GenBank and known resistant mutations.

Total RNA was extracted using QIAamp viral RNA mini kit (Qiagen, Valencia, CA, USA) according to the manufacturer's protocol. The samples were analyzed for influenza A and B as described in U.S. Centers of Disease Control (CDC)'s protocol, and positive result for influenza $A$ virus were subtyped for $\mathrm{H} 1$ with subtype-specific primers provided from CDC (9). The neuraminidase inhibitor oseltamivir's resistance was tested by detecting the H274Y mutation using sequence analysis, through partial-length cycle sequencing of the coding region for the viral NA. A set of primers was designed to determine a residue of the neuraminidase protein at the amino acid position 274 and PCR was performed as previously described (10). The sequence results were subjected to BLAST analysis by using the National Center for Biotechnology Information (NCBI) GenBank.

\section{RESULTS}

In 2007-2008 influenza season, Refik Saydam National Public Health Agency National Influenza Center collected specimens from nine provinces.

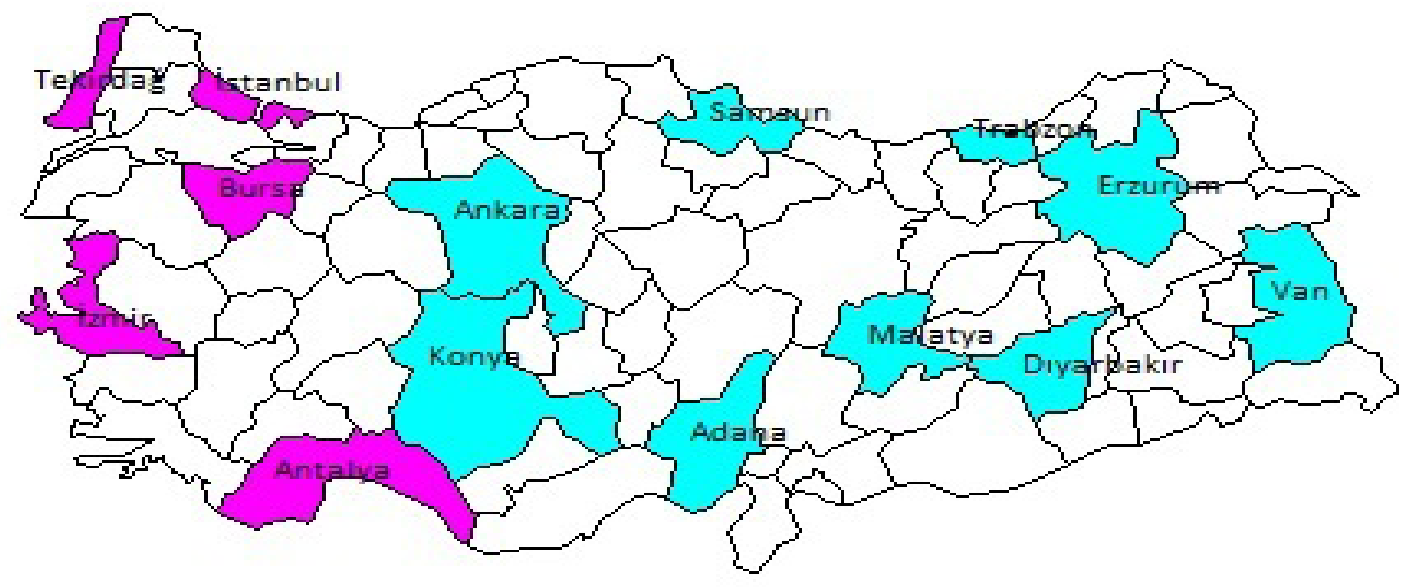

Figure 1. Sentinel Centers for Influenza Surveillance Programme *

* Purple coded provinces send samples to the labortories in İstanbul, while green coded provinces send samples to the laboratory in Ankara. 
All of the influenza A positive samples were tested for inluenza A (H1N1) viruses by real-time RT-PCR. In this study, we were able to amplify sequences for 20 seasonal influenza A (H1N1) viruses. Total of 20 influenza $A(\mathrm{H} 1 \mathrm{~N} 1)$ isolates were selected from 73 influenza A (H1N1) positive specimens of 20072008 influenza season. The NA genes of influenza viruses were sequenced and resistance was inferred by comparison with published sequences and known resistance mutations. The neuraminidase genes of all 20 seasonal influenza A (H1N1) viruses were successfully sequenced, and two of them (10\%) had histidine $(\mathrm{H})$ to tyrosine $(\mathrm{Y})$ substitution at position 274 (275 in N1 numbering) of the NA gene which indicates resistance to oseltamivir. The partial sequence analysis results of NA segments were submitted to National Center for Biotechnology Information (NCBI) GenBank with accession numbers GQ369800, GQ369799, GQ369798. According to the topological phylogenetic analysis, phylogenetic relationship of isolates from different parts of Turkey is shown in Table 1.

\section{DISCUSSION}

In the beginning of 2007-2008 influenza season, the emergence of resistance to oseltamivir among influenza A (H1N1) viruses was reported especially in Europe and the prevalence of oseltamivir-resistant influenza A (H1N1) viruses dramatically increased worldwide. By the early 2009 influenza season,

Table 1. Phylogenetic relationship of influenza A (H1N1) isolates from different provinces in central and eastern parts of Turkey in 2007-2008 influenza season

\begin{tabular}{|c|c|c|c|}
\hline $\begin{array}{l}\text { Sequence } \\
\text { product no }\end{array}$ & $\begin{array}{l}\text { Isolate date / } \\
\text { Isolate no }\end{array}$ & Isolate location & 274 amino acid changes \\
\hline 4 & $2007 / 1370$ & Konya & Histidine to tyrosine substitution at amino acid position 274 \\
\hline 5 & $2007 / 1558$ & Van & \multirow{18}{*}{ No change } \\
\hline 6 & $2008 / 1$ & Ankara & \\
\hline 7 & $2008 / 47$ & Trabzon & \\
\hline 8 & $2008 / 117$ & Van & \\
\hline 9 & $2008 / 136$ & Trabzon & \\
\hline 10 & $2008 / 141$ & Trabzon & \\
\hline 11 & $2008 / 149$ & Diyarbakir & \\
\hline 12 & $2007 / 1530$ & Diyarbakir & \\
\hline 13 & $2008 / 11$ & Adana & \\
\hline 14 & $2008 / 30$ & Erzurum & \\
\hline 16 & $2008 / 38$ & Ankara & \\
\hline 17 & $2008 / 43$ & Trabzon & \\
\hline 18 & $2008 / 68$ & Malatya & \\
\hline 19 & $2008 / 77$ & Van & \\
\hline 20 & $2008 / 112$ & Malatya & \\
\hline 29 & $2008 / 155$ & Hakkari & \\
\hline 30 & $2008 / 156$ & Hakkari & \\
\hline 31 & $2008 / 223$ & Trabzon & \\
\hline 33 & $2008 / 261$ & Adana & $\begin{array}{l}\text { Serine to alanine substitution at amino acid position } 265 \\
\text { Histidine to tyrosine substitution at amino acid position } 274\end{array}$ \\
\hline
\end{tabular}


recent reports showed that most influenza $A(\mathrm{H} 1 \mathrm{~N} 1)$ virus strains were resistant to oseltamivir $(1-8,11)$.

According to our previous study, total of 1157 clinical specimens were collected from nine provinces in 2007-2008 influenza season, and all of these samples were tested for influenza viruses by real-time RT-PCR. In this influenza season, 276 clinical specimens were found positive for influenza viruses. The predominant virus strain was evaluated as influenza A ( $55.7 \%)$, and the dominant subtype was detected as $\mathrm{H} 3$ (61.2\%). The 2007-2008 influenza season in Turkey was characterized by moderate clinical activity, and a dominance of influenza $A(H 3)(12)$.

The specimens were selected according to the CT level of the real-time PCR results. According to our knowledge, the resistance results were not affected by the specimen selection criteria, that we were used in this study.

In this study, we determined the resistance to neuraminidase inhibitors in influenza $\mathrm{A} \mathrm{H} 1$ isolates obtained during 2007-2008 influenza season in central and eastern parts of Turkey. Results of our analysis of 2007-2008 influenza season isolates revealed that $10 \%$ of the tested isolates were resistant to oseltamivir. During November 2007-April 2008, oseltamivir resistance was reported in 6 out of 30 (20\%) H1N1 isolates from western part of Turkey by Istanbul University Virology Laboratory (13). Up to June 2008, 52 countries worldwide reported similar results. The influenza A H1N1 viruses carried a specific neuraminidase mutation ( $\mathrm{H} 274 \mathrm{Y}$ ) that confers high-level resistance to oseltamivir, despite of low antiviral drug usage $(4,5,11)$.

In this report, we determined the presence of H274Y oseltamivir-resistant influenza A (H1N1) strains in central and eastern parts of Turkey. The results indicate that resistance to neuraminidase inhibitors (NAls) has begun to be detected in A/H1N1 isolates in Turkey in 2007-2008 influenza season.

\section{ACKNOWLEDGEMENTS}

Authors would like to thank to Turkish Ministry of Health, Primary Health Care Directarote and Health Directorates of Provinces and physicians and also thank to the technical staff of RSNPHA Virology Reference and Research Laboratory for their kind support.

\section{REFERENCES}

1. Avellon A, Cabrerizo M, Miguel T, Perez-Brena P, Tenorio A, Perez JL, et al. Widespread oseltamivir resistance in influenza A viruses (H1N1), South Africa Emerg Infect Dis, 2008; 14:1809-10.

2. Ciancio BC, Meerhoff TJ, Kramarz P, Bonmarin I, Borgen K, Boucher CA, et al. Oseltamivir-resistant inluenza A (H1N1) viruses detected in Europe during season 2007-8 had epidemiologic and clinical characteristics similar to co-circulating susceptible A(H1N1) viruses. Euro Surveill, 2009; 14(46): pii 19412.

3. Hauge SH, Dudman S, Borgen K, Lackenby A, Hungnes $\mathrm{O}$. Oseltamivir-resistant influenza viruses A (H1N1), Norway, 2007-08. Emerg Infect Dis, 2009; 15: 155-62.
4. Meijer A, Lackenby A, Hungnes O, Lina B, van der Werf S, Schweiger B, et al. Oseltamivir-resistant influenza viruses A (H1N1), Europe, 2007-08 season. Emerg Infect Dis, 2009; 15: 552-60.

5. Mossong J, Opp M, Gerloff N, Hau P, Kremer J, Lackenby A. Emergence of oseltamivir-resistant influenza A H1N1 virus during the 2007-2008 winter season in Luxembourg: Clinical characteristics and epidemiology. Antiviral Res, 2009; 84: 91-4.

6. Dharan NJ, Gubareva LV, Meyer JJ, OkomoAdhiambo M, McClinton RC, Marshall SA, et al. Infections with oseltamivir-resistant influenza A (H1N1) virus in the United States. JAMA, 2009; 301: 1034-41. 
7. Gerloff NA, Kremer JR, Mossong J, Opp M, Muller CP. Genomic Diversity of Oseltamivir-Resistant Influenza virus A (H1N1), Luxembourg, 2007-2008. Emerg Infect Dis, 2009; 15: 1523-4.

8. Burrel S, Roncin L, Lafon ME, Fleury H. Oseltamivir susceptibility in South-Western France during the 2007-8 and 2008-9 influenza epidemics and the ongoing influenza pandemic 2009. Euro Surveill, 2009; 14(38): pii 19334.

9. CDC.http://www.who.int/csr/resources/ publications/ swineflu/ realtimeptpcr/ en/index. html

10. Wright KE, Wilson GAR, Novosad D, Dimock C, Tan D, Weber JM. Typing and subtyping of influenza viruses in clinical samples by PCR. J Clin Microbiol, 1995; 33: 1180-84.
11. Vicente D, Cila G, Montes M, Mendiola J, PerezTrallero E. Rapid spread of drug-resistant inluenza A viruses in the Basque Country, Northern Spain, 2000-1 to 2008-9. Euro Surveill, 2009; 14(20): pii 19215.

12. Carhan A, Altas AB, Albayrak N, Uyar Y. Influenza surveillance results in 2007-2008 winter season in nine provinces of Turkey. Mikrobiol Bul, 2009; 43(2): 235-41.

13. Ciblak MA, Hasoksuz M, Escuret V, Valette M, Gul F, Bozkaya E, Badur S. Surveillance and oseltamivir resistance of human influenza A virus in Turkey during the 2007-2008 season. J Med Virol, 2009; 81(9): 1645-51. 


\section{Diyaliz sularının mikrobiyal kontaminasyon ve bakteriyel endotoksin testleri ile kontrolü}

\section{Control of dialysis water by microbial contamination and bacterial endotoxin tests}

Fesem BAȘARI ${ }^{1}, \quad$ Öznur UYANIK ${ }^{1}$

\begin{abstract}
ÖZET
Amaç: Bu çalıșmada Refik Saydam Hıfzıssıhha Merkezi Bașkanlığı Adana Hıfzıssıhha Enstitüsü Müdürlüğü Su ve Gıda Mikrobiyoloji Laboratuvarına kontrol amacıyla gelen diyaliz sularının mikrobiyal kontaminasyon ve bakteriyel endotoksin test sonuçları ile bu testlerin birbiriyle olan ilișkilerinin değerlendirilmesi amaçlanmıștır.
\end{abstract}

Yöntem: Bu çalıșmada Ocak 2009- Aralık 2010 tarihleri arasında laboratuvarımıza gelen 245 adet diyaliz suyu incelenmiștir. Mikrobiyal kontaminasyon örneklerin tamamında, bakteriyel endotoksin ise sadece 198 örnekte çalıșılmıștır. Mikrobiyal kontaminasyon çalışmaları, Plate Count Agar (PCA) ile yapılmıștır. Bakteriyel endotoksinin tespiti için ise Limulus Amoebocyte Lysate (LAL) yöntemi çalıșılmıștır. Mikrobiyal kontaminasyon ve bakteriyel endotoksin testlerinden elde edilen sonuçlar "Su Arıtma Sistemi Yönergesi” ve "Avrupa Farmokopesi”nde belirtilen kriterlere göre değerlendirilmiștir. Sonuçların yıllara göre değișimini karşılaștırmak için istatistiksel değerlendirmelerde ki-kare testi kullanılmıș ve

\section{ABSTRACT}

Objective: The aim of this study was to evaluate the microbial contamination and bacterial endotoxin levels in dialysis water samples sent to the Water and Food Microbiology Laboratory of the Adana Hygiene Institute Refik Saydam Hygiene Center, and to assess factors that might influence the results of these tests.

Method: Two hundred fourty five dialysis water samples sent to the laboratory between January 2009 and December 2010 were tested; all of them for microbial contamination and 198 of them for bacterial endotoxin levels. Microbial contamination was evaluated by using the Plate Count Agar (PCA) method while the Limulus Amoebocyte Lysate (LAL) assay was used for the detection of bacterial endotoxins. The results were evaluated according to the criteria of the "Directives on the Water Purification Systems" and "the European Pharmacopoeia". To compare the annual differences, the chi-square test was used for statistical evaluation and results

${ }^{1}$ Adana Hıfzıssıhha Enstitüsü Müdürlüğü, ADANA

İletişim / Corresponding Author : Fesem BASSARI

Adana Hifzıssıhha Enstitüsü Müdürlüğü, ADANA

Tel : +903224533341

E-posta/E-mail : fesemb@yahoo.com

Geliş Tarihi / Received : 06.06 .2011 Kabul Tarihi / Accepted : 15.02 .2012

DOI ID : 10.5505/TurkHijyen.2012.47135

Bașarı F, Uyanık Ö. Diyaliz sularının mikrobiyal kontaminasyon ve bakteriyel endotoksin testleri ile kontrolü. Turk Hij Den Biyol Derg, 2012; 69(1): 7-14. 
$\mathrm{p}<0,05$ olanlar istatistiksel olarak anlamlı kabul edilmiștir.

Bulgular: Mikrobiyal kontaminasyon testi ile toplam aerobik mikroorganizma sayısı (TAMS) 100 CFU/ml'den fazla olanların oranı \%11,7 iken, 2010 yılında bu oran $\% 4,8$ 'e gerilemiștir $(p>0,05)$. Bakteriyel endotoksin testinde ise 2009 yılında 0,25 IU ml'den fazla olanların oranı \%26,7'den, 2010'da \%16,5'e azalmıștır ( $p>0,05$ ). 2009-2010 yılları arasında mikrobiyal kontaminasyon testi ile çalıșlan toplam 245 örneğin 20 tanesinde $(\% 8,2)$ TAMS $100 \mathrm{CFU} / \mathrm{ml}$ 'den fazla bulunmuștur. Aynı yıllarda bakteriyel endotoksin testi çalıșılan 198 örneğin 43 (\%21,7)'ünde bakteriyel endotoksin değeri 0,25 $\mathrm{IU} / \mathrm{ml}$ 'den fazla bulunmuștur. Bakteriyel endotoksin testi sonucu 0,25 IU/ml'den fazla olan 43 örneğin $20(\% 46,5)$ 'sinde mikrobiyal kontaminasyon testi sonucu olușan TAMS $100 \mathrm{CFU/ml'den} \mathrm{fazla} \mathrm{saptanırken,} 23$ $(\% 53,5)$ 'ünde ise TAMS 100 CFU/ml'den az olarak tespit edilmiștir. Yıllara göre saptanan pozitifliklerde istatistiksel olarak anlamlı bir fark bulunamamıștır $(p>0,05)$.

Sonuç: Çalıșmamızda diyaliz sularında endotoksin seviyelerinin ölçülmesi, mikrobiyal kontaminasyon testi sonucunda elde edilen TAMS'ı tamamlayıcı özelliktedir. Bu nedenle endotoksin seviyelerinin, bakteri sayımı ile beraber yapılması gerektiği kanaatindeyiz. Diyaliz sularının periyodik kontrollerinin düzenli yapılması, laboratuvar testlerinin zamanında, doğru, güvenilir ve tam olması büyük önem tașımaktadır.

Anahtar Sözcükler: Diyaliz suyu, mikrobiyal kontaminasyon, endotoksin with $\quad \mathrm{p}<0.05$ were considered statistically significant.

Results: Total aerobic microorganism count (TAMC) found by microbial contamination test higher than 100 CFU/ml were $11.7 \%$ in 2009 , while only $4.8 \%$ ( $p>0.05$ ) in 2010 . On the other hand, in $26.7 \%$ of the dialysis water samples the levels of bacterial endotoxins was higher than $0.25 \mathrm{iU} / \mathrm{ml}$ in 2009, this percentage dropped to $16.5 \%$ in 2010 ( $p>0.05$ ). During 2009-2010, 245 microbial contamination tests were performed and in $20(8.2 \%)$ of the samples the TAMC values were higher than $100 \mathrm{CFU} / \mathrm{ml}$, while in 43 (21.7\%) out of 198 of the samples the bacterial endotoxin levels were higher than $0.25 \mathrm{iU} / \mathrm{ml}$. Out of 20 in 43 samples, a bacterial endotoxin levels were $>0.25 \mathrm{iU} / \mathrm{ml}$ were also found as microbiologically contaminated ( $>100$ $\mathrm{CFU} / \mathrm{ml}$ ), while in remaining 23 samples the level was $<100 \mathrm{CFU} / \mathrm{ml}$. There were no statistically significant differences in the percentages of positives found in 2009 and 2010.

Conclusion: The results of our study indicate that the detection of endotoxins is a complementary factor to microbial contamination in the bacteriological monitoring of dialysis waters. We recommend that level of endotoxin should be taken into account when the bacterial contamination test is used. It is important that periodic control of dialysis waters should be done by different reliable laboratory tests.

Key Words: Dialysis water, microbial contamination, endotoxin

\section{Gíriş}

Böbrek yetmezliği șikâyeti olan hastalar normal popülasyonla karșılaștırıldığında yașamları süresince daha fazla miktarlarda suya maruz kalmaktadırlar. Böbrek yetmezliği olan hastalara diyaliz sırasında her hafta yaklașık 360-400 litre su uygulanırken, sağlıklı bir insan her hafta yalnızca 14-15 litre su almaktadır. Bu hesaplamalara göre diyaliz hastaları yıllık olarak 18.000 -36.000 litre arasında suya maruz kalmaktadır. 
Suda bulunan düşük moleküler ağırlıklı maddeler (endotoksin, ekzotoksin ve bakteri kaynaklı DNA parçaları) diyaliz yoluyla direkt olarak hastaların kan dolaşımına geçebilmektedir (1-3). Kontamine sulardan korunmada mide asidi ve bağırsak bariyeri, diyaliz membranından çok daha etkilidir. Hemodiyaliz işlemi süresince hasta kanı yarı geçirgen bir membranla bağlantı halinde olup, diyaliz sıvısının bileșenleri diyalize bağlı komplikasyonların olușmasında önemli bir rol oynamaktadır. Mikroorganizmalar membran porlarından geçemeyebilir, fakat bakteriyel endotoksinler (lipopolisakkaritler), ekzotoksinler ve bakteri kaynaklı kısa DNA parçaları diyaliz membranından geçebilir ve böylece hasta kanına karıșabilirler (1-4).

Filtrasyon, reverozmozis ve dezenfeksiyon için etkili yöntemlerin yeterince sağlanamaması gibi sebeplerden dolayı suların yeterince arıtılamaması, hemodiyaliz hastalarında önemli oranda bakteriyemi pirojenitesine neden olmaktadır. Nonfermantatif gram-negatif bakteriler distile sularda bile hızlıca çoğalabilmektedirler. Hemodiyaliz solüsyonlarında glükoz ve bikarbonat bulunmasından dolayı bu bakteriyel üreme daha hızla olabilmekte ve endotoksinin yüksek seviyelerine ulașmasına yol açmaktadır. Üstelik ișlem görmüș su ve diyalizat örnekleri klinikte kullanılan çeșitli antibiyotiklere ve dezenfektanlara karşı dirençli bakteriler tarafından enfeksiyon kaynağı olabilmektedir $(3,4)$. Bakteriyel biyofilm ve buna bağlı kontaminantlar hemodiyaliz hastalarında monosit ve makrofajların aktivasyonu ve proinflamatuvar sitokinlerin (interlökin-1, interlökin-6, tümor nekrozis faktör) serbest kalması, enflamasyonu tetikleyerek kısa ve uzun dönemde yaşamı kısaltan çeșitli komplikasyonlara neden olmaktadir (1,5-7).

Bu çalışmamızda Refik Saydam Hıfzıssıhha Merkezi Bașkanlığı Adana Hıfzıssıhha Enstitüsü Müdürlüğü Su ve Gıda Mikrobiyoloji Laboratuvarına kontrol amaçlı gelen diyaliz sularında mikrobiyal kontaminasyon, bakteriyel endotoksin seviyeleri ve bu testlerin birbiriyle olan ilișkilerinin incelenmesi amaçlanmıștır.

\section{GEREÇ VE YÖNTEM}

Ocak 2009- Aralık 2010 tarihleri arasında Akdeniz ve Güneydoğu Anadolu Bölgelerinde bulunan bazı üniversite, eğitim ve araștırma, devlet ve özel hastanelerin diyaliz merkezleri ile özel diyaliz merkezlerinden laboratuvarımıza gelen 245 adet diyaliz suyu retrospektif olarak incelenmiștir. Mikrobiyolojik olarak çalșsılması talep edilen parametreler doğrultusunda mikrobiyal kontaminasyon ve bakteriyal endotoksin testleri yapılmıștır. Mikrobiyolojik ekim metodu olarak plak dökme yöntemi kullanılmıștır. Her örnekten paralel olmak üzere, bir dilüsyon yapmadan bir de 1/10 oranında dilüsyon yaparak toplam dört adet ekim yapılmıştır. Ekim için steril boș petri plaklarına, dilüsyonlu ve dilüsyonsuz örneklerden birer $\mathrm{ml}$ diyaliz suyu örneği konulmuștur. Önceden hazırlanarak steril tüplere aktarılan ve $4{ }^{\circ} \mathrm{C}$ 'de saklanan besiyeri, çalıșma esnasında kaynatılarak eritilip, daha sonra su banyosu kullanılarak yaklașı $45{ }^{\circ} \mathrm{C}$ 'ye getirilmiștir. Tüplerdeki Plate Count Agar (PCA) besiyeri, örneğin bulunduğu petri plakları üzerine yavașça dökülmüştür. Besiyeri ve örneğin homojen dağılımı sağlanmıştır. Besiyeri donduktan sonra petri plakları ters çevrilerek $35 \pm 1{ }^{\circ} \mathrm{C}$ 'de beș gün süre ile inkübe edilmiștir. İnkübasyon sonrası her plakta üreyen koloniler sayılmıș, ortalaması alınmıș ve bir ml'deki koloni sayısı hesaplanmıștır. Koloni sayısı 100 CFU/ ml'den fazla olanlar pozitif olarak değerlendirilmiștir. Her çalıșmada dilüsyonda kullanılan steril distile saf sudan bir ml steril petri plağına aktarılmıș ve aynı yöntemle besiyeri eklenerek herhangi bir üreme olup olmadığı kontrol edilmiștir $(8,9)$.

Bakteriyel endotoksini saptamak için laboratuvara gelen 198 örneğe Limulus Amoebocyte Lysate (LAL) Jel-Clot testi kullanılmıştır. Üretici firmadan elde edilen kitin (Pyrosate Kit, Rapid Endotoxin Detection, Catalog: PSD10, Cape Cod- MA02536 USA) çalıșma yöntemlerine göre; steril bir pipetle $0,5 \mathrm{ml}$ örnekten alınarak numune tüplerine konmuștur. Daha sonra bu tüplerden $0,25 \mathrm{ml}$ alınarak kontrol 
tüpüne aktarılmıștır. $37{ }^{\circ} \mathrm{C}$ 'de 30 dakika inkübasyona bırakılmıștır. Değerlendirme daha önceki çalıșmalar göz önüne alınarak șu șekilde yapılmıștır: Numune tüplerinde katılașma yoksa numune 0,25 IU/ml'den az endotoksin, katılașma varsa 0,25 IU/ml'den fazla endotoksin içermektedir $(10,11)$.

Mikrobiyal kontaminasyon ve bakteriyel endotoksin testleri Su Arıtma Sistemi Yönergesi (2009) ve Avrupa Farmokopesi (2005)'nde belirtilen kriterlere göre değerlendirilmiștir $(9,11,12)$.

Sonuçların yıllara göre değișimini karșılaștırmak için istatistiksel değerlendirmelerde ki-kare testi kullanılmıștır. $\mathrm{p}<0,05$ olanlar istatistiksel olarak anlamlı kabul edilmiștir.

\section{BULGULAR}

Laboratuvara gelen 245 örnekten mikrobiyal kontaminasyon testi sonucunda TAMS 100 CFU/ml'den fazla olanlarının oranı 2009 yılında \%11,7 iken, 2010 yılında \%4,8'e düșmesine karşın istatistiksel olarak anlamlı bir fark bulunamamıștır (ki-kare=2,97, $p>0,05)$. İki yıllık periyotta mikrobiyal kontaminasyon testi çalıșılan toplam 245 diyaliz suyu örneğinin
$20(\% 8,2)$ 'sinde bakteri koloni sayıs 100 CFU/ml'den fazla bulunmuștur. Çalıșmamızda 2009 yılında LAL testi 0,25 IU/ml'den fazla olanların oranı \%26,7'den, 2010 yılında \%16,5'e gerilemesine karșın istatistiksel olarak anlamlı bir fark bulunamamıștır (ki-kare=2,51, p>0,05). Toplamda 198 örnekte ise bakteriyel endotoksin çalıșılmış ve çalıșılan örneklerin $43(\% 21,7)$ 'ünde bakteriyel endotoksin değeri 0,25 IU/ml'den fazla bulunmuștur. Bakteriyel endotoksini 0,25 $\mathrm{IU} / \mathrm{ml}$ 'den fazla bulunan 43 örneğin $20(\% 46,5)$ 'si TAMS 100 CFU/ml'den fazla olan örneklerde, $23(\% 53,5)$ 'ü ise mikrobiyal kontaminasyon testi sonucu 100 CFU/ml'den az olan örneklerde saptanmıștır. Bakteriyel endotoksini 0,25 IU/ml'den fazla bulunan 43 örneğin mikrobiyal kontaminasyonla ilișkisi yönünden yıllara göre değișimi karşılaștırılmıștır. Hem mikrobiyal kontaminasyonu $100 \mathrm{CFU} / \mathrm{ml}$ 'den hem de bakteriyel endotoksini 0,25 $\mathrm{IU} / \mathrm{ml}$ 'den fazla olan örneklerin sayısı ile mikrobiyal kontaminasyonu 100 CFU/ml'den az ve bakteriyel endotoksini 0,25 IU/ml'den fazla olanların sayısı 2010 yılında gerilemesine karşın (Tablo 1) istatistiksel olarak anlamlı bir fark bulunamamıștır (ki-kare=0,32, $p>0,05)$.

Tablo 1. Diyaliz sularının mikrobiyal kontaminasyon ve bakteriyel endotoksin dağılımları

\begin{tabular}{|c|c|c|c|c|c|c|c|c|}
\hline \multirow[b]{2}{*}{ Yil } & \multicolumn{3}{|c|}{ Mikrobiyal Kontaminasyon } & \multicolumn{3}{|c|}{ Bakteriyel Endotoksin } & \multicolumn{2}{|c|}{$\begin{array}{l}\text { Toplam çalıșılan örneklerde } \\
\text { Mikrobiyal Kontaminasyon ve } \\
\text { Bakteriyel Endotoksin ilișkisi }\end{array}$} \\
\hline & $\begin{array}{l}\text { Örnek } \\
\text { Sayısı } \\
\text { n }\end{array}$ & $\begin{array}{l}<100 \mathrm{CFU} / \mathrm{ml} \\
\text { Olanlar } \\
\mathrm{n}(\%)\end{array}$ & $\begin{array}{l}>100 \mathrm{CFU} / \mathrm{ml} \\
\text { Olanlar } \\
\mathrm{n}(\%)\end{array}$ & $\begin{array}{l}\text { Örnek } \\
\text { Sayısı } \\
\text { n }\end{array}$ & $\begin{array}{l}<0,25 \mathrm{IU} / \mathrm{ml} \\
\text { Olanlar } \\
\mathrm{n}(\%)\end{array}$ & $\begin{array}{l}>0,25 \mathrm{IU} / \mathrm{ml} \\
\text { Olanlar } \\
\mathrm{n}(\%)\end{array}$ & $\begin{array}{l}>100 \mathrm{CFU} / \mathrm{ml}, \\
>0,25 \mathrm{IU} / \mathrm{ml} \\
\text { Olanlar } \\
\mathrm{n}(\%)\end{array}$ & $\begin{array}{l}<100 \mathrm{CFU} / \mathrm{ml} \\
>0,25 \mathrm{IU} / \mathrm{ml} \\
\text { Olanlar } \\
\mathrm{n}(\%)\end{array}$ \\
\hline 2009 & 120 & $106(88,3)$ & $14(11,7)$ & 101 & $74(73,3)$ & $27(26,7)$ & $14(51,9)$ & $13(48,1)$ \\
\hline 2010 & 125 & $119(95,2)$ & $6(4,8)$ & 97 & $81(83,5)$ & $16(16,5)$ & $6(37,5)$ & $10(62,5)$ \\
\hline Toplam & 245 & $225(91,8)$ & $20(8,2)$ & 198 & $155(78,3)$ & $43(21,7)$ & $20(46,5)$ & $23(53,5)$ \\
\hline
\end{tabular}




\section{TARTIȘMA}

Endotoksinler Gram-negatif bakterilerin ve bazı siyanobakterilerin hücre duvarlarının dış çeperinin bir parçasını olușturan ve lipopolisakkaritlerden olușan bileșenlerdir. Endotoksinlerin tespitine yönelik bir yöntem olan LAL testi ilk kez 1960'larda Levin ve Bang tarafından gerçekleștirilmiștir (13). Diyaliz sularının kabul edilebilir mikrobiyolojik ve kimyasal limitlerine yönelik standartlar da yine 1960'lı yıllarda kabul görmeye bașlamıștır. Sonraki yıllarda ülke, bölge ve uluslararası alanlarda diyaliz sularının limitlerini belirlemeye yönelik çeșitli standartlar yayınlanmıștır (14).

Ülkemizde ise Türk Nefrolojisi Derneği'nin 2009 yılı verilerine göre renal replasman tedavisi gören hasta sayısı her geçen gün hızla artmaktadır. 2009 yılı sonu itibariyle 59.443 hastanın renal replasman tedavisi gördüğü tespit edilmiștir. Son yıllarda böbrek yetmezliği prevalansı milyon nüfus bașına 819 , insidansı ise 197 olarak bildirilmiștir. Hemodiyalizin $(\% 78,5)$ en sık kullanılan tedavi yöntemi olduğu, bunu transplantasyon $(\% 12,4)$ ve periton diyalizinin $(\% 9,1)$ takip ettiği bildirilmiștir (15).

Brezilya'da 1996 yılında 60'tan fazla diyaliz hastası su sisteminde, mavi/yeșil alglerden biri olan Microcystis aeroginosa'nın aşırı üremesi sonucu karaciğer yetmezliğinden ölmüştür. Çünkü bu algler karaciğer için oldukça toksik olan siyanotoksin üretmektedirler. $\mathrm{Bu}$ nedenle diyaliz hastalarının kullanacağı hemodiyaliz ünitesi diyaliz suları temiz olmalı ve hiçbir organik komponent içermemelidir (2). Diyaliz sularının mikrobiyal kontamisyonunun kabul edilebilir sınırlar altında tutulabilmesi, diyaliz merkezlerinde ciddi bir sorundur. Mikrobiyolojik kalitenin iyileștirilmesi bașta hastalar olmak üzere bu birimlerde çalıșanlar için de son derece önem arz etmektedir (16).

Japonya'da Ikuto ve ark. (17) diyaliz sularının mikrobiyal kontaminasyonunu saptamak amaciyla yaptıkları çalıșmalarında koloni sayısını $100 \mathrm{CFU/}$ ml'den fazla olarak 2006 yılında \%96,69 ve 2007 yılında \%97,4 oranında bulmușlardır. Giuseppe ve ark. (18) ise çeșitli Avrupa ülkeleri, Amerika Birleșik Devletleri ve Kanada gibi ülkelerde yapılmış çok merkezli çalışmalarda \%7-35 oranında mikrobiyal kontaminasyonu 200 CFU/ml'den fazla olarak bildirdiklerini belirtmișlerdir. Bizim çalıșmamızda mikrobiyal kontaminasyonu $100 \mathrm{CFU} / \mathrm{ml}$ 'den fazla olanların oranı 2009'da \%11,7 iken, 2010'da \%4,8'e gerilemesine karşın istatistiksel olarak anlamlı bir fark bulunamamıștır (ki-kare=2,97, $p>0,05$ ). Toplamda 245 örnekte mikrobiyal kontaminasyon testi çalıșılmış ve $20(\% 8,2)$ örnekte TAMS 100 CFU/ ml'den fazla bulunmuștur (Tablo 1). Bu sonuç Japonya'dan bildirilen çalıșmadan biraz yüksek olmakla birlikte literatürlerde diğer çalışmalara benzer sonuçlar elde edilmiștir (18) . Bu farlılıkların nedeni kullanılan yöntem ve besiyerlerine de bağlı olabilir (19). Nitekim, Klas van der ve ark. (20) ile Adriano ve ark. (21) iki farklı besiyeri (Triptik soya agar ve Reasoner's 2A) ve farklı yöntemler (limiti $100 \mathrm{CFU} / \mathrm{ml}$ 'den fazla veya $200 \mathrm{CFU} / \mathrm{ml}$ 'den fazla) kullanarak yaptıkları çalıșmalarında farklı sonuçlar elde etmișlerdir. Bu sonuçlara göre eğer koloni sayısı için limit 200 CFU/ml'den fazla olarak kabul edilseydi sadece bir numune $200 \mathrm{CFU} / \mathrm{ml}$ 'den fazla olarak değerlendirilmiș olacaktı. Diğer sekiz numune 100 $\mathrm{CFU} / \mathrm{ml}-200 \mathrm{CFU} / \mathrm{ml}$ arasında, 11 numune ise 100 CFU/ml'den fazla olarak kaydedilmiștir.

Ülkelerin diyaliz sularında kullandıkları standartlar da bakteriyel endotoksin testi açısından değișiklik göstermektedir (19). Japonya'da Ikuto ve ark. (17) çalıșmalarında diyaliz sularının bakteriyel endotoksini 2006 'da \%89,0 IU/ml ve 2007 'de $\% 93,6$ oranında $0,050 \mathrm{IU} / \mathrm{ml}$ 'in altında bildirmișlerdir. Litvanya'dan Skarupskiene ve ark. (1) çalıșmalarında \%86 oranında $0,25 \mathrm{IU} / \mathrm{ml}$ 'in altında bildirmişlerdir. Mısır'dan El-Koraie ve ark (16) çalıșmalarında çeșitli ünitelerden aldıkları örneklerde bakteriyel endotoksin oranının \%57-100 oranında 0,25 IU/ml'den fazla olduğunu bildirmișlerdir. Çalıșmamızda bir önceki yıla göre LAL testi $0,25 \mathrm{IU} / \mathrm{ml}$ 'den fazla olanların oranının \%26,7'den \%16,5'e gerilemesine karșın 
istatistiksel olarak anlamlı bir fark bulunamamıștır (ki-kare=2,51, P>0,05). Hem mikrobiyal kontaminasyon hem de bakteriyel endotoksin sonuçlarında, limit değerlerin üzerinde çıkanların bir önceki yıla göre azalması istatistiki olarak anlamlı olmasa da diyaliz merkezlerindeki iyileșmelerin bir göstergesi olarak düşünülebilinir. Toplamda 198 örnekte LAL testi çalıșılmış ve $43(\% 21,7)$ 'ünde 0,25 IU/ml'den fazla bulunmuștur (Tablo 1 ). Bu sonuç Japonya ve Litvanya'dan bildirilen sonuçlara göre yüksek iken, Mısır'dan bildirilen sonuçlara göre oldukça düşüktür. $\mathrm{Bu}$ durum diyaliz merkezlerinin özelliklerine ve kullanılan yöntemlerin farklılığına bağlı olabilir.

Almanya'dan Bambauer ve ark (22) 30 diyaliz merkezinde arıtılmıș su örneklerinde ve diyalizatlarda bakteriyel kontaminasyon ve endotoksin araștırmışlar, su örneklerinde bakteriyel konsantrasyonu \%17,8 ve diyalizat örneklerinde $\% 11,7$ oranında, endotoksin oranlarını ise sırası ile \%12,2 ve \%27,5 pozitif bulmuşlardır. Amerika'dan Klein ve ark (23) 51 akut ve kronik diyaliz merkezinde arıtılmış su örneği ve rastgele seçtikleri diyalizat örneklerinde mikrobiyal kontamisyonu sirası ile \%35,3 ve \%19,0 olarak bildirirken, her iki ülkenin araștırmacıları da bakteriyel endotoksin ile mikrobiyal kontaminasyon arasında tutarsızlık gözlendiğini bildirilmișlerdir $(22,23)$. Düşük seviyede bakteri üremesi ve yüksek seviyede endotoksin konsantrasyonuna, diyaliz borucuklarındaki bakteriyel tutunma, yapıșma veya biyofilm gibi nedenlerle endotoksin ve bakteri parçalarının diyalizata karıșmasının yol açtığı düșünülmektedir (14,24). Bazı araștırmacılar da su ve diyaliz örneklerinde bakteriyel üreme ile endotoksin konsantrasyonları arasında bir bağlantı kurulamamasının nedenini farklı bakteri türlerinin farklı endotoksin aktivitelerine sahip olabileceği şeklinde açıklamıșlardır. Ayrıca lipopolisakkaritlerin mikroorganizma yıkıntıları sonucu serbest kalmasına bağlı olarak düșük CFU/ml ve yüksek endotoksin değerleri ile ilișkili olabileceği bildirilmiștir $(16,25)$.
Bizim çalıșmamızda da bakteriyel endotoksin oranlarının bir önceki yıla göre düșmüș olması pozitif bir gelișmedir (Tablo 1). Ancak, 0,25 IU/ ml'den fazla bulunan 43 örneğin $20(\% 46,5)$ 'sinde mikrobiyal kontaminasyonun 100 CFU/ml'den fazla olması beklenen bir sonuç iken, ilginç olarak 23 $(\% 53,5)$ örnekte bakteriyel endotoksin, mikrobiyal kontaminasyon $100 \mathrm{CFU} / \mathrm{ml}$ 'den az olan örneklerde 0,25 IU/ml'den fazla olarak saptanmıștır. Her iki grubun sayılarında da 2009 yılına göre 2010 yılında gerileme görülmesine karşın istatistiksel olarak anlamlı bir fark bulunamamıștır (ki-kare=0,32, $p>0,05)$. Diğer araștırmacılara uygun olarak bizim çalıșmamızda da mikrobiyal kontanminasyonu limit değerinin üstünde çıkanlardan $(\% 46,5)$ mikrobiyal kontaminasyonu limit değerinin altında çıkanlarda $(\% 53,5)$ bakteriyel endotoksin oranı daha fazla bulunmuștur. Diğer araștırmacılara uygun olarak çalıșmamızda mikrobiyal kontaminasyon ile bakteriyel endotoksin arasında yeterli bir ilișki bulunamamıștır.

Diyaliz sularının kalitesi bu suları olușturan bileșenlere ve bunların kimyasal özelliklerine, hazırlanış șekline, kullanmadan önce kalite kontrollerinin yapılmasına, iyi ve modern cihazların kullanılmasına, kullanılan filtrelerin kalitesine ve özelliklerine bağlı olarak değișmektedir. Ayrıca diyaliz suyu sistemlerinin bakımına en uygun dezenfeksiyon yönteminin seçilmesi, çıkabilecek olası problemlerin önceden tahmin edilebilmesi ve çözüm yollarının önceden belirlenmesi, uluslararası kalite standartlarının uygulanması sonuçlara etkili olabilmektedir $(2,3,14,18,24)$.

Bakteriyel endotoksin ve diğer mikrobiyal kontaminantlar hemodiyaliz hastalarında bağıșıklık sisteminde görev yapan hücreleri uyarıp, proinflamatuvar sitokinlerin serbest kalmasını sağlamakta, enflamasyonu tetiklemekte, buda kısa ve uzun dönemde yașamı kısaltan çeșitli komplikasyonlara neden olmaktadır (1,5-7). Bu durum göz önünde bulundurularak çalıșmamızda pozitif çıkan örneklerin telefon, faks gibi iletișim 
araçlarıyla hızlı bir șekilde geri bildirimleri yapılmış ve hastalarda oluşabilecek olası komplikasyonlar önlenmeye çalıșılmıștır.

Sonuç olarak; çalıșmamızda endotoksin seviyelerinin ölçülmesi diyaliz sularının bakteriyolojik olarak gözlemlenmesinde mikrobiyal kontaminasyonu tamamlayıcı bir özellik tașımaktadır. Bu nedenle endotoksin seviyelerinin, bakteri sayımına ilaveten yapılması gerekmektedir. Ayrıca, ülkemizde son yıllarda diyaliz hastalarının artışı göz önünde bulundurulduğunda, yetkili kurumlarca periyodik kontrollerin yapılması, laboratuvar testlerinin zamanında, doğru, güvenilir ve tam olması büyük önem taşımaktadır.

\section{KAYNAKLAR}

1. Skarupskienè I, Bumblytè IA, Tamošaitis D, Venterienè J, Kuzminskis V. The level of endotoxins in hemodialysis water and dialysate in Lithuanian hemodialysis centers. Medicina (Kaunas), 2010; 46(8): 556-60.

2. $A$ HMAD S. Essentials of water treatment in Hemodialysis. Hemodialysis International, 2005; 9: 127-34.

3. Borges CRM, Lascowski KMS, Filho NR, Pelayo JS. Microbiological quality of water and dialysate in a haemodialysis unit in Ponta Grossa-PR, Brazil J Appl Microbiol, 2007; 103: 1791-97.

4. Hoenich NA, Ronco C, Levin R. The importance of water quality and haemodialysis fluid composition. Blood Purif, 2006; 24: 11-8.

5. Cappelli G, Perrone S, Inguaggiato P, Ferramoska E, Albertazzi A. Design of water treatment plants in the year 2000 and beyond. Saudi J Kidney Dis Transplant, 2001; 12(3): 398-405.

6. Eyileten T, Yenicesu M, Altun B, Çakar M, Karaman M, Ay SA, et al. Hemodiyaliz hastalarında diyalizatın mikrobiyolojik niteliğinin enflamasyon belirteçleri üzerine etkisi. Turk Neph Dia ve Transpl Derg, 2010; 19(3): 162-9.

7. Cappelli G, Sereni L, Scialoja MG, Morselli M, Perrone S, Ciuffreda A, et al. Effects of biofilm formation on haemodialysis monitor disinfection. Nephrol Dial Transplant, 2003; 18: 2105-11.
8. Anonmymous. Su Kalitesi-Kültürü yapılabilen Mikroorganizmaların Sayımı-Agar Besiyerinde Așılama ile Koloni Sayımı. Türk Standartları Enstitüsü, TS EN ISO 6222. Şubat 2002.

9. Total Viable Aerobic Count, European Pharmacopoeia 5.0, (2005) Vol.1, Strasbourg, France, pp. 154. ISBN/ISSN :978-92-871-5281-7.

10. Pyrosate Kit, Rapid Endotoxin Detection, Catalog: PSD10, Cape Cod- MA02536 USA.

11. Bacterial Endotoxins, European Pharmacopoeia 5.0, (2005) Vol.1, Strasbourg, France, pp. 161. ISBN/ISSN :978-92-871-5281-7.

12. Anonmymous. Su Arıtma Sistemi Yönergesi. Sağlık Bakanlığı Temel Sağıık Hizmetleri Genel Müdürlüğü. 17.04.2009 tarih ve 15873 sayılı.

13. Reyes MI, Perez CM, Negron EL. Microbiological assessment of house and imported bottled water by comparison of bacterial endotoxin concentration, heterotrophic plate count and fecal coliform count. PRHSJ, 2008; 27(1):21-6.

14. Ward RA. Worldwide guidelines for the preparation and quality management of dialysis fluid and their implementation. Blood Purif, 2009; 27(1): 2-4.

15. Süleymanlar G, Seyahi N, Altıparmak MR, Serdengeçti K. Türkiye'de renal replasman tedavilerinin güncel durumu: Türk Nefroloji Derneği Kayıt Sistemi 2009 Yılı Rapor Özeti. Turk Neph Dia ve Transpl Derg, 2011; 20 (1): 1-6. 
16. El-Koraie AF, Hazzah WA, Abbas AA, El-Shazly SA. Bacteriological monitoring of dialysis fluid in 2 hemodialysis units in Alexandria, Egypt. Saudi Med J, 2007; 28(8): 1234-8.

17. Masakane I, Takemoto Y, Nakai S, Tsubakihara Y, Akiba T, Watanabe Y, et al. Bacteriological water quality in the central dialysis fluid delivery system from the survey of the Japanese Society for Dialysis Therapy. Blood Purif, 2009; 27(1): 11-6.

18. Pontoriero G, Pozzoni P, Andrulli S, Locatelli F. The quality of dialysis water. Nephrol Dial Transplant, 2003; 18(7): 21-5.

19. Nystrand R. Microbiology of Water and Fluids for Hemodialysis. J Chin Med Assoc, 2008;71(5): 223-9.

20. Linde KVD, Lim BT, Rondeel JMM, Antonissen LPMT, Jong GMTD. Improved bacteriologcal surveillance of haemodialysis fluids: A comparison between tryptic soy agar and Reasoner's 2A media. Nephrol Dial Transplant, 1999; 14: 2433-7.
21. Bugno A, Almodóvar AAB, Pereira TC. Enumeration of Heterotrophic Bacteria in water for dialysis: Comparison of the Efficiency of Reasoner'2 Agar and Plate Count Agar. Braz J Microbiol, 2010; 41: 15-8.

22. Bambauer R, Schauer M, Jung WK, Daum V, Vienken J. Contamination of dialysis water and dialysate: A survey of 30 centers. ASAIO J, 1994;40(4):1012-6.

23. Klein E, Pass T, Harding GB, Wright R, Million C. Microbial and endotoxin contamination in water and dialysate in the central United States. Artif Organs, 1990;14(2):85-94.

24. Perez-Garcia R, Rodriguez-Benitez POC. Why and how monitor bacterial contamination of dialysate? Nephrol Dial Transplant, 2000; 15: 760-4.

25. Lonnemann G. Assessment of the quality of dialysate. Nephrol Dial Transplant, 1998; 13 (5): 17-20. 


\title{
İstanbul'da hayat kadınları ile hastanemizin kadın hastalıkları ve doğum kliniği hastalarındaki vajinal kandidiyazın görülme sıklığının 10 yıl önceki oranla kıyaslanması
}

\section{Comparison of the incidence of vaginal candidiasis among prostitutes in Istanbul and patients of the Obstetrics and Gynecology Clinic of the Cerrahpașa Medical Faculty}

\author{
Erdal POLAT ${ }^{1}$, Serhat SiREKBASAN ${ }^{1}, \quad$ Burcu AYDIN ${ }^{2}$, Zehra YILDIRIM ${ }^{1}$, \\ Yaşar BAĞDATLI ${ }^{1}$, İsmail ÇEPNi ${ }^{2}$, Tayfur ÇiFT ${ }^{2}$, Nezihe D. BALTALI ${ }^{3}$
}

\section{ÖZET}

Amaç: Kandida türleri ile olușan kandidiyaza dünyanın her tarafında rastlanmaktadır. 1998 yılında İstanbul'da hayat kadınları ve poliklinik hastalarından alınan vagina akıntı örnekleri ile yaptığımız çalıșmada kandidiyaz oranı poliklinik hastalarında $\% 30,3$, hayat kadınlarında ise \%11,4 olarak bulunmuştur. Aradan geçen 10 yıllık süre zarfında hayat kadınları ve poliklinik hastalarında kandidiyaz oranındaki değișikliğin belirlenmesi amaçlanmıştır.

Yöntem: Bu çalıșmada Deri ve Tenasül Hastalıkları Hastanesi'ne getirilen 93 hayat kadını ve İstanbul Üniversitesi Cerrahpașa Tıp Fakültesi Kadın Hastalıkları ve Doğum Anabilim Dalı Polikliniğine bașvuran ve trikomoniyazis vaginiti șüphesi olan 114 hasta olmak üzere toplam 207 hastadan alınan vaginal akıntı örneği araștırılmıștır. Örneklerden hazırlanan yayma preparatlar Gram boyanarak mikroskopta incelenmiștir. Ayrıca bir adet sıvı ve bir adet katı Sabouraud besiyerine ekilerek kandida kültürü yapılmıștır.

Bulgular: Toplam 207 vaginal akıntı örneğinin 31 (\%14,9)'inde kandida üremiș, bunların 25 (\%80,7)'inde Gram boyama ile maya hücreleri görülmüștür.

\section{ABSTRACT}

Objective: Candidiasis caused by Candida species has been reported worldwide in humans. In a study conducted in 1998 with samples of vaginal discharges of outpatients and prostitutes in İstanbul, a prevelance of candidiasis of $30.3 \%$ and $11.4 \%$, respectively was found. The aim of this study was to determine the changes in the rate of candidiasis in prostitutes and outpatients during the past ten years.

Method: Vaginal discharge samples of 207 patients with suspected trichomoniasis vaginitis were examined. The samples were obtained from 93 prostitutes admitted to the Hospital of Skin and Venereal Diseases and from 114 outpatients admitted to Istanbul Medical Faculty, Department of Obstetrics and Gynecology Outpatient Clinic. Smears prepared from the samples were examined under a microscope by Gram staining. Additionally, Candida culture tests were performed by inoculating a fluid and a solid Sabouraud medium.

Results: Candida was identified in 31 (14.9\%) of the 207 samples of vaginal discharges examined, while yeast cells were detected in 25 of them $(80.7 \%)$ by

' İstanbul Üniversitesi, Cerrahpaşa Tıp Fakültesi, Mikrobiyoloji ve Klinik Mikrobiyoloji Anabilim Dalı, ISTANBUL

${ }^{2}$ İstanbul Üniversitesi, Cerrahpaşa Tıp Fakültesi, Kadın Hastalıkları ve Doğum Anabilim Dalı, ISTANBUL

${ }^{3}$ Deri ve Tenasül Hastalıkları Hastanesi, iSTANBUL

İletissim / Corresponding Author : Erdal POLAT

İstanbul Üni., Cerrahpaşa Tip Fak., Mikrobiyoloji ve Klinik Mikrobiyoloji Anabilim Dalı, ISTANBUL

Tel : +902124143000_ E-posta/E-mail : erdalp@istanbul.edu.tr

Geliş Tarihi / Received : 20.05.2011 Kabul Tarihi / Accepted : 24.11.2011

DOI ID : 10.5505/TurkHijyen.2012.71676

Polat E, Sirekbasan S, Aydın B, Yıldırım Z, Bağdatı Y, Çepni I, Çift T, Baltalı ND. İstanbul’da hayat kadınlan ile hastanemizin kadın hastalıkları ve doğum kliniği hastalarındaki vajinal kandidiyazın görülme sıklığının 10 yıl önceki oranla kıyaslanması. Turk Hij Den Biyol Derg, 2012; 69(1): 15-20. 
Kandidaların $21 \quad(\% 67,7)$ 'ini Candida albicans türü olușturmaktadır. 93 hayat kadının 10 (\%10,8)'unda, 114 poliklinik hastasının $21 \quad(\% 18,4)$ 'inde kandida ürediği tespit edilmiștir. Bunların $21 \quad(\% 67,7)$ 'ini C. albicans, beșini $(\% 16,1)$ Candida krusei ikisini $(\% 6,5)$ Candida tropicalis ve üçünü $(\% 9,7)$ Candida spp. olușturmaktadır.

Sonuç: Bakteriyal vajinozdan sonra en çok karșılașılan vaginal kandidiyazis sıklıkla her yaștan kadında görülen bir hastalıktır. On yıl öncesine göre poliklinik hastalarındaki kandidiyaz oranında azalma görüldüğü halde hayat kadınlarındaki kandidiyaz oranında bir azalma görülmemiștir. Yaptığımız bu epidemiyolojik çalıșma enfeksiyon açısından sosyal gelișmișlik düzeyinin belirlenmesinin önemini vurgulamaktır.

Anahtar Sözcuikler: Vaginal kandidiyaz, poliklinik hastaları, hayat kadınları

\section{GíRiş}

Kandidalar tek hücreli, ökaryotik, tomurcuklanarak (blastospor) veya ikiye bölünerek çoğalan, 3-4 $\mu \mathrm{m}$ boyutlarında yuvarlak veya oval mayalardır. Kandida türlerinin insandaki parazitliği sonucunda oluşan kandidiyaza dünyanın her tarafında rastlanmaktadır (1). Deri, ağız, üst solunum yolları, gastrointestinal sistem ve anal bölgenin mukozasında normal flora elemanı olarak bulunan kandidaların 200'den fazla türü bulunmaktadır. İmmun sistemi bozulmuş kișilerde, kanser dolayısı ile kemoterapi ve radyoterapi tedavisi, steroidlerin ve geniș spektrumlu antibiyotiklerin yaygın kullanımı; katater uygulamaları gibi tedavi yöntemleri normal mikrobiyal florayı değiștirerek mayaların fırsatçı patojen olarak infeksiyonlara neden olmalarına yol açabilirler (2-4).

Kandida cinsi mayalar kadınların \%50'sinin vajina florasında normal olarak bulunabildiği gibi vulvovajinit etkeni olarak da karșımıza çıkabilmektedirler. Erișkin kadınların yaklașık \%75'inin hayatları boyunca en az bir kez kandida vulvovajiniti geçirdiği ve bunların da \%45'inin tekrarladığı bildirilmektedir (5-9).
Gram staining. Twenty-one (67.7\%) of the Candida identified, belonged to the species Candida albicans, five (16.1\%) were Candida krusei, two (6.5\%) Candida tropicalis and three (9.7\%) Candida spp.. Candida was reported in $10(10.8 \%)$ of the 93 prostitutes, and in 21 $(18.4 \%)$ of outpatients.

Conclusion: Second to bacterial infections of vagina, vaginal candididiasis is the most common disease in women of all ages. Even though a reduction in the prevalance of candidiasis was observed in outpatients as compared to ten years ago, this was not the case in prostitutes. We think that this kind of epidemiological studies are important in determining the level of hygienic conditions in different social groups.

Key Words: Vaginal candidiasis, out patients, prostitutes

Kandidiyazda kesin tanı, etkenin izolasyonu ve tanınması ile mümkündür. İzolasyon yöntemi için Sabouraud'nun dekstrozlu agarı kullanılmaktadır. Ayrıca potasyum hidroksit $\mathrm{KOH}$ ile lam-lamel arası hazırlanan ve Gram boyanan preparatlarda kandidalar görülebilir (1).

Çalıșmamızda, Deri ve Tenasül Hastalıkları Hastanesi'ne getirilen hayat kadınları ile hastanemiz Kadın Hastalıkları ve Doğum Polikliniği'ne gelen trikomonas vajiniti șüphesi olan hastalardan alınan örnekler incelenmiștir. Elde edilen sonuçlar 1998 yılında kürsümüzde yapılan benzer çalıșmadaki sonuçlar ile karșılaștırılarak aradan geçen süre zarfındaki değișikliğin belirlenmesi amaçlanmıștır.

\section{GEREÇ ve YÖNTEM}

Çalıșmaİstanbul'dahayatkadınlarıilehastanemizin kadın hastalıkları ve doğum kliniği hastalarındaki Trichomonas vaginalis görülme sıklığının $10 \mathrm{yıl}$ önceki oranla kıyaslanması șeklinde planlanmıștır. 
Deri ve Tenasül Hastalıkları Hastanesi'ne getirilen 93 hayat kadını ve Cerrahpașa Tıp Fakültesi Kadın Hastalıkları ve Doğum Anabilim Dalı Polikliniği'ne gelen özellikle sarı kötü kokulu köpüklü bol akıntısı ve vulvada kaşıntı klinik belirtileriyle trikomoniyaz șüphesi uyandıran 114 hasta olmak üzere toplam 207 hasta çalıșmaya alınmıștır.

Bu hastalardan steril iki eküvyon ile alınan vajina akıntı örnekleri yarım saat içinde incelemeye alınmıștır. Örneklerden hazırlanan yayma preparatlar Gram boyanarak mikroskopta incelenmiș ve bir adet sıvı, bir adet katı Sabouraud besiyerine ekilerek kandida kültürü yapılmıștır. $37{ }^{\circ}{ }^{\circ}$ 'lik etüvde 72 saat tutulan kültürlerde kandidanın üremediği kültürler negatif, ürediği kültürler ise pozitif olarak değerlendirilmiștir.

Kültürde üreyen kandidaların tür düzeyinde identifikasyonu için; insan serumuna ekilerek $37{ }^{\circ} \mathrm{C}$ 'de 2-2,5 saat tutulduktan sonra çimlenme borusu ve misır unlu agara ekilerek 72 saat sonra klamidospor olușturup olușturmadığına bakılmıștır. İnsan serumunda çimlenme borusu misır unlu agarda klamidospor olușturanlar Candida albicans, olușturmayanlar ise Candida spp. olarak kabul edilmiștir. Kandidaların tümü kromojenik agara ekilerek $37^{\circ} \mathrm{C}$ 'de ürettikleri enzim ile besiyerindeki kromojenik substrat reaksiyonu sonucu olușan renk değișimine bakılarak yeșil olanlar C. albicans, metalik mavi renkte olanlar Candida tropicalis ve gri-pembe renkte olanlar Candida krusei, bu renklerin dışında olanlar ise Candida spp. olarak değerlendirilmiștir (Şekil 1).

\section{BULGULAR}

Toplam 207 vajina akıntı örneğinin 25 (\%12)'inde Gram boyama ile maya hücreleri görülmüş olup, kültürde ise 31 (\%15)'inde Candida spp. üremiștir. Doksanüç hayat kadınının 10 (\%10,8)'unda, 114 poliklinik hastasının ise $21(\% 18,4)$ 'inde Candida sp. ürediği görülmüștür. Bunların 21 (\%67,7)'ini C. albicans, $5(\% 16,1)$ 'ini C. krusei $2(\% 6,5)$ 'sini ise C. tropicalis ve $3(\% 9,7)$ 'ünü Candida spp. olușturmaktadır.

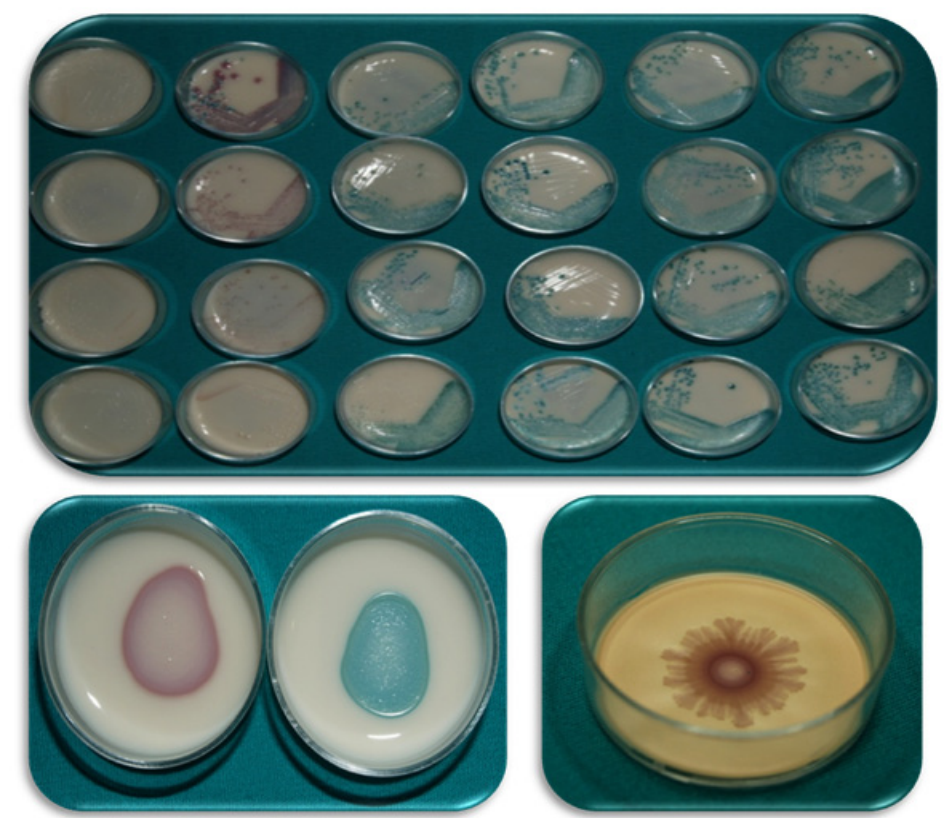

Şekil 1. Kandida krom agarda değișik kandida türlerinin görünümü 
Hastaların sosyo-demografik özelliklerine bakıldığında poliklinik hastalarının 18-44 yaș aralığında (ortalama yaș: 33,3) olduğu saptanmıștır. Hayat kadınları 17-48 yaș (ortalama yaș: 32,6) aralığındadır. Hayat kadınlarının 25 (\%26,8)'i ilkokul, 25 (\%26,8)'i ortaokul, $31(\% 33,3)$ 'i lise ve $12(\% 12,9)$ 'si üniversite mezunudur. Poliklinik hastalarının 12 (\%10,5)'si okuryazar değildir ve kalanların $33(\% 28,9)$ 'ü ilkokul, $31(\% 27,9)$ 'i ortaokul, $27(\% 23,6)$ 'si lise ve $10(\% 8,7)$ 'u üniversite mezunudur. 93 hayat kadının 60 (\%64,3)'ı hayatında sadece bir defa, $25(\% 26,8)$ 'i iki defa ve kalan sekiz $(\% 8,6)$ hasta üç ve üzeri vajinit tanısı almış ve tedavi olmuştur. 114 poliklinik hastasının $11(\% 9,6)$ 'inin hayatında hiç kaşıntı, akıntı gibi klinik yakınması olmamıș ve vajinit tanısı almamıștır. Kalan $82(\% 71,9)$ hasta bir defa, $12(\% 10,5)$ hasta iki defa ve $8(\% 7,1)$ hasta üç ve üzeri vajinit tanısı almıș ve tedavi olmuștur.

\section{TARTIŞMA}

Kandidaların; ağız, üst solunum yolları, vajen ve derinin normal mikroorganizma florasında yer aldığını ve özellikle immun sistemi baskılayan bazı faktörlere bağlı olarak, fırsatçı enfeksiyonlara neden olduğu bilinmektedir (6). C. albicans en sık izole edilen tür olsa da C. tropicalis, C. glabrata, C. krusei, C. parapsilosis, C. stelloidea, C. pseudotropicalis, C. lusitaniae gibi diğer türlerle olan infeksiyonlar da rapor edilmektedir (10-12). Bakteriyal vajinozdan sonra en çok karşılașılan vajinal kandidiyaz sıklıkla her yaștan kadında görülen bir hastalıktır $(13,14)$.

Ülkemizde ve İstanbul Üniversitesi, Cerrahpașa Tıp Fakültesi, Mikrobiyoloji ve Klinik Mikrobiyoloji Anabilim Dalımızda direkt mikroskobi, Gram boyama ve/veya kültür yöntemi ile yapılan değișik çalıșmalarda vajinal kandidiyazın \%11,7 ile \%39,92 arasında olduğu belirlenmiștir. Çalışmalarımızdan elde edilen sonuçların diğer çalıșmaların sonuçları ile benzer oranda görülmektedir (15-23). Ancak çalıșmalarımızdaki sonuçlara bakıldığında vajinal kandidiyazın poliklinik hastalarında, hayat kadınlarına göre 2-3 kat daha yüksek olduğu görülmektedir. Bu durumun hayat kadınlarının poliklinik hastalarından daha sık ve düzenli olarak kontrole gitmesine, hayat kadınlarının birçoğunun cinsel yolla bulașan hastalıklardan korunmak için bariyer kontrasepsiyon yöntemi kullanmasına, bunun aksine poliklinik hastalarının çoğunun kontrasepsiyon yöntemi olmayan coitus interruptus yöntemi kullanmasına ve aslında cinsel yolla bulașabilecek tüm enfeksiyonlara daha açık olmasına bağlı olduğunu düșünmekteyiz.

1998 yılında yaptığımız çalıșmada vajinal kandidiyaz oranı poliklinik hastalarında \%30,3, hayat kadınlarında \%11,4 olarak bulunmuștur (24). Yaptığımız bu çalıșma da ise hayat kadınının \%10,8, poliklinik hastasının ise $\% 18,4$ oranında vajinal kandidiyaz tespit edilmiștir. Saptadığımız oranları karșılaștırdığımızda aradan geçen 10 yıl süre zarfında poliklinik hastalarındaki kandidiyaz oranında belirgin bir azalma görülürken, hayat kadınlarındaki kandidiyaz oranında pek de bir azalmanın olmadığı gözlenmektedir.

Çalıștığımız 207 vajinal akıntı örneğinden üretilen 31 kandida cinsinin $21(\% 67,7)$ 'ini C. albicans olușturmaktadır. C. albicans'ın oranındaki bu yüksekliğin Anabilim Dalımızda daha önceden yapılan çalıșmalarda bulunan oranla ve değișik çalıșmalardan elde edilen sonuçlar ile uyumlu olduğu görülmektedir (22-25).

Değerli ve ark., vajinal akıntı șikayeti olan kadınlardan aldıkları toplam 286 örneğin $28(\% 9,7)$ tanesinde $T$. vaginalis, $93(\% 32,5)$ tanesinden kandida cinsi mantar üretmișlerdir (26).

Çalıșma İstanbul'da hayat kadınları ile hastanemizin kadın hastalıkları ve doğum kliniği hastalarındaki $T$. vaginalis görülme sıklığının $10 \mathrm{yıl}$ önceki oranla kıyaslanması șeklinde planlanmıștır. Bundan dolayı i.ü. Cerrahpaşa Tıp Fakültesi Kadın Hastalıkları ve Doğum Anabilim Dalı polikliniğine gelen hastalardan trikomoniyaz vajiniti șüphesi olanlardan materyal alınmıștır. Ancak trikomoniyaz 
vajiniti șüphesi ile alınan materyallerin birinde $(\% 0,9) T$. vaginalis üremesine rağmen $21(\% 18,4)$ 'inde kandida cinsi mantarlar üremiștir. On yıl önce yaptığımız benzer çalıșmada da T. vaginalis; poliklinik hastalarında $\% 3,4$ hayat kadınlarında ise $\% 4,6$ oranında, vajinal kandidiyaz ise poliklinik hastalarında $\% 30,3$, hayat kadınlarında \%11,4 oranında bulunmuştur (24). Ancak detaylı bir anamnez ve muayene aslında bu iki klinik tablonun ayrımını sağlamaktadır. Bu durum vajinal kaşıntı gibi bazı klinik semptomların özellikle trikomoniyazis ve kandidiyazis tanısında karışıkığa yol açtığını düşündürmektedir. Özellikle sarı köpüklü kötü kokulu akıntı ve vulvada kaşıntı bizi trikomoniyazis lehine yönlendirirken; beyaz renkli peynir kesiği șeklinde kokusuz akıntı ve vajende yoğun kașıntı kandidiyazis lehine yönlendirmektedir.

On yıl sonra tekrarlanan bu çalıșmada gerek vajinal kandidiyazın gerekse vajinal trikomonyazın görülme sıklığında anlamlı bir azalmanın olduğu görülmektedir. Akıntı ile gelen vajinitli veya vulvovajinitli kadınlarda $T$. vaginalis vajiniti tanısı düşünülürken aynı zamanda kandidiyazdan da șüphelenilmesinin yararlı olacağı kanısındayız. Yaptığımız bu epidemiyolojik çalıșma ile sosyal gelișmişlik düzeyinin enfeksiyon açısından belirlenmesinde önemli bir veri olacağı düșüncesindeyiz.

\section{KAYNAKLAR}

1. Unat EK, Yücel A, Altaș K, Samastı M. Unat'ın Tıp Parazitolojisi. 5. Baskı. İstanbul: Cerrahpașa Tıp Fak. Vakfı Yayınları. Doyuran Matbaası, 1995: 744-57.

2. Alan MS, Caron A. A practical guide to medically important fungi and the diseases they cause. 1st ed. Lippincott-Raven. Philadelphia, New York, 1996: 34-58.

3. Coskun Ö. Kandidemi saptanan hastalarda bilinen risk faktörlerinin değerlendirilmesi ve hemokültürlerinden izole edilen kandida türlerinin amfoterisin- $B$ ve flukonazole in vitro antifungal duyarlılıklarının incelenmesi. Uzmanlık tezi, Gülhane Askeri Tıp Akademisi, İnfeksiyon Hastalıkları ve Klinik Mikrobiyoloji Anabilim Dalı, 2000.

4. Koçoğlu E, Bayram A, Balcı İ. Klinik örneklerden izole edilen kandida türleri ve antifungal duyarlılıkları. Van Tıp Derg, 2005; 12 (3): 195-200.

5. Bilgehan H. Klinik Mikrobiyolojik Tanı. 5. Baskı. İzmir: Barıș Yayınları, 2009: 390-400.
6. Birinci A, Cihan ÇÇ, Bilgin K, Acuner Ç, Durupınar $\mathrm{B}, 2005$. Candida türlerinde slime üretiminin araștırılması. Türk Mikrobiyol Cem Derg, 2005; (35): 163-6.

7. Monif RG. Classification and pathogenesis vulvovaginal candidiasis. Am J Obstet Gynecol, 1985; 152 (2): 935-39.

8. Rein MF. Vulvovaginitis and Cervitis. Mandell GL, Bennett JE, Dolin R, eds. Mandell, Douglas and Bennett's Principles and Practice of Infectious Diseases. Vol. 1, 4th ed. Churchill Livingstone, New York. 1995: 1074-90.

9. Sobel JD. Epidemiology and pathogenesis of recurrent vulvovaginal candidiasis. Am J Obstet Gynecol, 1985; 152 (2): 924-35.

10. Göller S. Klinik örneklerden izole edilen Candida'ların tiplendirilmesi ve antifungal ajanlara duyarıııkları. Uzmanlık tezi, Dokuz Eylül Üniversitesi Tıp Fakültesi Mikrobiyoloji Anabilim Dalı, 1999. 
11. Nguyen MH, Peacock JE Jr, Morris AJ, Tanner DC, Nguyen ML, Snydman DR, et al. The changing face of candidemia: emergence of non-Candida albicans species and antifungal resistance. Am J Med, 1996; 100 (2): 617-23.

12. Voss A, le Noble JL, Verduyn Lunel FM, Foudraine NA, Meis JF. Candidemia in intensive care unit patients: risk factors for mortality. Infection, 1997; 25 (1): 8-11.

13. Battaglia F, Mariani L, Anglana F, Milite V, Quattrini $M$, Plotti $F$, et al. Vulvovaginal candidiasis: a therapeutic approach. Minerva Ginecol, 2005; 57 (2): 131-9.

14. Sheary, B, Dayan L. Recurrent vulvovaginal candidiasis. Aust Fam Physician, 2005; 34 (1): 147-50.

15. Aktan G. Gebe olan ve olmayan kadınlarda vulvovaginit etkeni olan mayalar. Türk Mikrobiyol Cem Derg, 1988; 18 (3-4): 116-21.

16. Altanlar N. Vulvuvajinal candidiasis olgularından izole edilen Candida'ların türlere göre dağılımı. Ankara Ecz Fak Derg,1999; 28(1): 61-70.

17. Aydın F, Tosun I, Ekmek Ü, Bilekli C, Köroğlu H, Soylu $\mathrm{H}$, et al. Vulvovajinal candidiasis olgularından izole edilen mayaların türlere göre dağılımı. Mikrobiyol Bült, 1996; 30: 51-5.

18. Berktal M, Gül A, Yılmaz H, Bozkurt H, Yavuz MT, Dalkılıç AE. Sağlıklı gebe kadınlarda Candida'ların vaginal kolonizasyonu ve tür dağılımı. Van Tıp Derg, 1995; 2 (2): 10-3.

19. Cengizhan L, Kıyan M, Cengiz AT, Uğurel MȘ. Vaginal akıntı kültürlerinde üretilen mikroorganizmalar ve antibiyotik duyarılıkları. XXV. Türk Mikrobiyoloji Kongresi, 8-11 Eylül, Bursa. 1992.
20. Çolak D, Özgür K, Mutlu G. Vaginal akıntı örneklerinden izole edilen Candida türleri. XXVI. Türk Mikrobiyoloji Kongresi, 11-15 Nisan, Antalya. 1994.

21. Gönlüm A, Gün H, Haznedaroğlu T, Baysallar M, Başustaoğlu A, Özyurt M, 1994. Vajinal akıntı örneklerinden izole edilen mayaların türlere göre dağılımı. XXVI. Türk Mikrobiyoloji Kongresi, 11-15 Nisan, Antalya. 1994.

22. Kahraman M. Candida'ların tanımlanmasındaki bazı yöntemlerin karșılaștırılması ve bunların bir kısım antifungallere duyarlılık durumu. Uzmanlık Tezi. i.ü. Cerrahpașa Tıp Fakültesi Mikrobiyoloji ve Klinik Mikrobiyoloji Anabilim Dalı, 1995.

23. Yücel A, Öztürk R, Kahraman M, Çașkurlu H. Değișik kimya maddeleri emdirdiğimiz pullar (diskler) ile mayaların ayrımı. T Parazitol Derg, 1993; 17 (3-4): 154-5.

24. Yücel A, Polat E, Kahraman M, Çepni i, Öztaș Ö, Tırak Ç, Kayım H, Baltalı ND. Poliklinik hastalarıyla hayat kadınlarından alınan vajina akıntısı örneklerinde Candida türü mantarların mikroskop ve kültür sonuçları. T Parazitol Derg, 1998; 22 (2): 204-7.

25. Yücel A, Çepni I, Polat E, İpek H, Aydın Y, Gezer A, Aksu MF. Üreme yollarındaki șikayetleriyle bașvuran 480 kadının vagina akıntısında bulduğumuz Candida türleri. T Parazitol Derg, 1997; 21 (4): 395-8.

26. Değerli K, Laçin S, Özbakkaloğlu B, Sivrel A, Özkütük N, Özbilgin A. Vagina akıntı șikayeti olan kadınlarda Trichomonas vaginalis ve Candida spp. yaygınlığının araștırılması. T Parazitol Derg, 1997; 21 (4): 366-8. 


\title{
Kauçuk yapıda Foley idrar sondalarının sitotoksisitesinde çinko bileșiklerinin olası rolü
}

\section{The possible role of zinc compounds on the cytotoxicity of latex Foley urinary catheters}

\author{
Mehmet Kürșat DERici'1 , Hakan BÜZKAYA ${ }^{1}, \quad$ Ferat ŞAHIN ${ }^{1}$
}

\section{ÖZET}

Amaç: Doğal kauçuk yapıda olan sonda ve cerrahi eldivenlerin farklı hücreler üzerindeki sitotoksik etkileri olduğu bildirilmiștir. Bu etkilerin azaltılması amacıyla gümüș ya da polimerik (hidrojel, silikon, politetrafloroetilen) kaplamalar gibi değișik kaplama teknikleri geliștirilmiștir. Kaplama sondaların üretim așamasında, kauçuk sondalara benzer șekilde hızlandırıcı olarak çinko bileșikleri kullanılmaktadır. Bu çalıșmanın amacı, kauçuk sondaların in vitro sitotoksik etkilerini, silikon kaplanan kauçuk sondalar ile karşılaștırmak ve toksisite nedenini araștırmaktır.

Yöntem: Doğal kauçuk, silikon kaplı kauçuk ve \%100 silikon olmak üzere üç grupta sekiz farklı markadan 48 sondanın sitotoksik etkileri, fare bağ dokusu fibroblast hücre kültüründe (L-929) nitel (görüntüleme ve skorlama) ve nicel (MTT) yöntemler ile araștırılmıștır. Sonda özütlerinde bulunan element düzeyleri Alevli Atomik Absorbsiyon Spektrofotometresi (AAS) ile incelenmiștir.

Bulgular: Negatif kontrol olarak kullanılan standart polietilen ile karșılaștırıldığında, \%100 silikon sondalardan elde edilen özütlerin uygulandığı hücrelerde \% canlılık

\section{ABSTRACT}

Objective: The cytotoxic effects of natural rubber gloves and urinary catheters on different cells have been earlier reported. In order to reduce these effects, various coating techniques such as silver or polymer (hydrogel, silicone, polytetrafluoroethylene (PTFE)) coatings have been developed. However, during manufacturing process of silicone-coated rubber catheters, similar to latex catheters, zinc compounds, which have cytotoxic effects are added to the natural rubber base. The aim of this study was to compare the in vitro cytotoxic effects of rubber catheters with the silicone-coated rubber and to investigate the causes of the toxic effect.

Method: The cytotoxic effects of total 48 urinary catheters in three different structure (natural rubber, silicone, silicone-coated rubber) and 8 different brands were analysed in mouse connective tissue fibroblast cell culture (L-929) by qualitative (imaging and scoring) and quantitative (MTT) methods. The levels of the elements in catheter extracts were examined in an Atomic Absorption Spectrophotometer (AAS).

Results: Compared with standard polyethylene used as a negative control, the extracts from $100 \%$ silicone did not change vitality of the fibroblast cells

${ }^{1}$ Türkiye Illaç ve Tıbbi Cihaz Kurumu, İlaç, Biyolojik ve Tıbbi Ürünler Laboratuvar Dairesi, ANKARA

İletişim / Corresponding Author : Mehmet Kürşat DERICI

Türkiye İlaç ve Tıbbi Cihaz Kurumu, İlaç, Biyolojik ve Tibbi Ürünler Laboratuvar Dairesi, ANKARA Geliş Tarihi / Received : 08.08 .2011

Tel : +903124982150_ E-posta/E-mail : derici@tr.net Kabul Tarihi / Accepted : 05.02.2012

DOI ID : 10.5505/TurkHijyen.2012.78790

Derici Mk, Büzkaya H, Șahin F. Kauçuk yapıda Foley idrar sondalarının sitotoksisitesinde çinko bileșiklerinin olası rolü. Turk Hij Den Biyol Derg, 2012; 69(1): 21-30. 
oranı $(\% 95,43 \pm 5,39)$ değișmezken, doğal kauçuk $(\% 8,57$ $\pm 0,54)$ ve silikon kaplı kauçuk sondalarda (\%21,0 \pm 2,52) canlılığın anlamlı olarak azaldığı görülmüștür $(p<0,01)$. AAS ile ölçülen sonda özütleri çinko düzeyleri silikon sondalarda $0,11 \pm 0,01$, kauçuk sondalarda 4,78 $\pm 0,66 \mathrm{mg} / \mathrm{L}$, silikon kapl grupta ise $2,78 \pm 0,33 \mathrm{mg} / \mathrm{L}$ olarak bulunmuș ve toksik etkiler arasında korelasyon tespit edilmiștir. Düzeyleri araștırılan diğer elementler ( $\mathrm{Cr}, \mathrm{Ag}, \mathrm{Cu}, \mathrm{Bi}, \mathrm{Pb}, \mathrm{Fe}, \mathrm{Co}, \mathrm{Cd}$ ) arasinda anlamlı bir fark bulunamamıștır. Metal iyon șelotörü olan etilendiamintetraasetik asit (EDTA)' in hücreler için toksik olmayan düzeyi (5 $\mu \mathrm{M})$ uygulama öncesinde özüt içerisine eklendiğinde kauçuk yapıda sondaların sitotoksisitesi anlamlı olarak geriye dönmüștür (sırasıyla \%101,05 \pm 5,86 ve $100,24 \pm 4,9$ ).

Sonuç: Çalıșmamız, doğal kauçuk ve silikon kaplı kauçuk sondaların sitotoksik etkilerinin silikon sondalardan anlamlı olarak daha yüksek olduğunu göstermektedir. Bu toksisiteden, üretim aşamasında çeșitli amaçlar ile kauçuğa eklenen çinko bileșiklerinin sorumlu olduğu kanıtlanmıștır. Silikon kaplı sondaların sitotoksik etkileri arasında görülen anlamlı fark, üretim teknolojisinin, kalite için önemli bir faktör olduğunu ortaya koymaktadır. Farklı kaplama yöntemlerinin araștırılması veya kauçuk sondaların yerine toksik olmadığı kanıtlanan ürünler kullanılması, kliniklerde üriner kateterizasyondan kaynaklanan komplikasyonların azaltılması için çözüm olabilir.

Anahtar Sözcükler: Sitotoksisite, idrar sondaları, kaplama, çinko bileșikleri

\section{GíRiş}

Üriner kateterlerin tarihsel gelișimine bakıldığında farklı dizayn ve hammaddelerin kullanıldığı görülmektedir. Milattan sonra üçüncü yüzyılda Yunan hekimlerin kullanıldığı bilinen bakır, altın, bronz gibi metallerin yanı sıra Mısır'da papirusdan yapılan kateterlerin kullanıldığı da gösterilmiștir (1). Ilk elastik kateter, 1779 yılında Fransa'da Bernard tarafından geliștirilmiș daha sonra 1853'de bu tasarıma retansiyon baloncuğu da eklenmiștir. Bu gün kullanılan, doğal kauçuk yapıda üretilen ve Foley kateter olarak bilinen tip ise 1930'ların ortalarında Dr. Frederick B. Foley tarafından geliștirilmiștir
$(95.43 \% \pm 5.39)$, while the natural rubber $(8.57 \% \pm$ $0.54)$ and the silicone-coated rubber $(21.0 \% \pm 2.52)$ decreased this significantly $(p<0.01)$. The analysis of the catheter extracts by the AAS method showed that the zinc levels of rubber and silicon-coated catheter extracts were $4.78 \pm 0.66 \mathrm{mg} / \mathrm{L}$ and $2.78 \pm 0.33$ $\mathrm{mg} / \mathrm{L}$, respectively and correlated with the observed toxic effects. No significant differences were found in the levels of elements such as $\mathrm{Cr}, \mathrm{Ag}, \mathrm{Cu}, \mathrm{Bi}, \mathrm{Pb}$, $\mathrm{Fe}, \mathrm{Co}$ and $\mathrm{Cd}$. The addition of the metal chelating agent ethylenediaminetetracetic acid (EDTA) in a non-toxic level $(5 \mu \mathrm{M})$ for the cells, reversed the latex cytotoxicity $(101.05 \% \pm 5.86$ and $100.24 \pm 4.9$, respectively).

Conclusion: Our study demonstrated that both the rubber and the silicone-coated rubber catheters have cytotoxic effects. Zinc compounds, which are added to rubber in the production stage for a variety of purposes, have proven to be responsible for this toxicity. The significant difference between the cytotoxic effects of the silicone-coated rubber and latex catheters suggests that the production technology is an important factor for the quality. Different coating methods have to be investigated or the products proved to be non-toxic should be used instead of the rubber catheters, in order to reduce complications in urinary catheterization in clinical practice.

Key Words: Cytotoxicity, urinary catheters, coating, zinc compounds

(2). Günümüzde sağlık alanında, üriner tıkanma ve inkontinens sorunlarının tedavisinde en sık kullanılan medikal ürünlerin idrar sondaları olduğu görülmektedir.

Ülkemizdeki kullanımıyla ilgili kesin kayıtları bulunmamakla birlikte, yakın tarihte İngiltere'de yapılan bir araștırma, uzun süreli üriner kateterizasyon prevalansının yetișkin hasta grubunda \%0,03-0,07, 75 yaș üzerinde \%0,5'e, 85 yaș ve üzerinde ise \%2 ye ulaștığını göstermektedir (3). İleri yaș hastalarda idrar yolu sorunları, sondaların kullanım sıklığı yanında sondaların uygulama sürelerini de uzatmaktadır. 
Araștırmalar idrar sondalarının bu hastalarda 1-3 ay arası sürelerde ve değiștirilerek kullanıldığını göstermektedir $(3,4)$.

Günümüzde kullanılan idrar sondalarının büyük çoğunluğu, orijinal Foley katetere benzer șekilde doğal kauçuk veya poliisopren adlı maddeden imal edilmektedir. Doğal kauçuk (lateks) bol bulunduğu için nispeten düșük maliyetli olmasının yanında kolay ve kısa sürede șekillendirilebilmesi, ișlenebilmesi nedeniyle aynı zamanda üretim maliyetlerini de azalttığından kateter üretiminde halen sıklıkla kullanılmaktadır. Aynı zamanda doğal kauçuğun, yoğunluk, sertlik, uzama katsayısı, gerilme kuvveti gibi fiziksel özelliklerinden kaynaklanan avantajları bu hammaddenin yerine koyulabilecek alternatiflerini sınırlamaktadır. Ancak özellikle 1980'li yıllarda, kauçuk yapıda malzemelerin neden olduğu zayıf biyouyumluluk, yüksek idrar yolu enfeksiyonu yatkınlığı ve lümen tıkanması sıklığında artıș gibi sorunlar, sağlık çalıșanları tarafından fark edilmiș ve bildirilmiștir (5). Bunun dişında insan immun sisteminin, kauçuk içeriğinde bulunan proteinler ile aktivasyonu sonucu gelișen ve lateks alerjisi olarak tanımlanan bir tablo da ortaya konmuștur (6). Tüm bu sorunlar, sonda üreticilerinin yeni çözümler aramasına neden olmuş ve günümüzde gümüș, hidrojel, politetrafloroetilen (PTFE) veya silikon kaplanmıș kauçuk sondaların ya da tamamen silikon hammaddesinin kullanıldığı sondaların üretimi ile sonuçlanmıștır. Kauçuğun polimerik kaplama ile muamele edilmesi sonucunda biyo-uyumluluğunun iyileștiği, nispeten yüzey kayganlığının artması nedeniyle uygulanmasının kolaylaștığı, uygun esneklik ve sertlik değerlerine ulaşılabildiği iddia edilmektedir (5). \%100 silikon sondalar ise fiziksel, kimyasal ve biyouyumluluk özellikleri yönünden, üriner kateterizasyon ile ilgili olduğu bildirilen bir çok sorun için kesin çözüm olarak görülmekle birlikte üretim maliyetleri diğer sonda tiplerine oranla yüksektir. Bunlara ek olarak sondaların çeșitli antibiyotikler ile muamele edilmesi ile hem mikroorganizmaların yapıșmasının engellendiği hem de sitotoksik etkilerinin azaltıldığı gösterilmiștir (7).
Bu çalıșmanın amacı ülkemizde kullanılmakta olan çeșitli marka ve serilerinden oluşan üç tip idrar sondasının (doğal kauçuk, silikon kaplanmıș doğal kauçuk ve \%100 silikon) hücre kültürü yöntemi kullanılarak in vitro sitotoksisitelerinin ortaya konması ve bunun olası nedenlerinin araștırılmasıdır.

\section{GEREÇ VE YÖNTEM}

Çalıșmaya, Refik Saydam Hıfzıssıhha Merkezi Bașkanlığı, İlaç ve Kozmetikler Araștırma Müdürlüğü, Farmakoloji Laboratuvarına, Sağlık Bakanlığı tarafından piyasa gözetim ve denetimi kapsamında, testlerinin yapılması istemi ile gönderilen, üç farklı hammaddeden (doğal kauçuk, silikon, silikon kaplı doğal kauçuk) üretilen sekiz farklı marka, toplam 48 adet idrar (Foley) sondası alınmıștır. Çalıșılacak sondalar, seriler içerisinden rastgele sayılar tablosu kullanılarak seçilmiștir.

Sitotoksisite Testleri: Sondalarda özütleme çalıșmaları, TS EN ISO 10993-12 “Tıbbi Cihazların Biyolojik Değerlendirilmesi: Bölüm 12; Numune Hazırlama ve Referans Malzemeler. Mart 2010" standardına uygun șekilde yapılmıștır (8). Sonda özütleri, \%5 fetal sığır serumu (FBS) içeren MEM (Minimal Essential Medium) vasatı içerisinde 24 saat $37{ }^{\circ} \mathrm{C}$ koșullarda ve sondaların bütünlüğü korunarak elde edilmiștir. Sitotoksisite çalıșmaları ise TS EN ISO 10993-5 “Tıbbi Cihazların Biyolojik Değerlendirilmesi”: Bölüm 5- Vücut dıșı sitotoksisite deneyleri. Temmuz 2010" standardında belirtildiği șekilde nitel ve nicel deneyler kullanılarak yapılmıștır (9). Deneyler, NCTC klon 929 (L-929) fare subkutanöz bağ doku hücreleri (fibroblast) üzerinde gerçekleștirmiștir. Hücreler, Tarım Bakanlığı Şap Enstitüsü Müdürlüğü Hücre Bankası'ndan sağlanmıștır. Standartta tarif edilene uygun șekilde çözdürülen hücrelerin daha sonra üç pasajı yapılarak çalıșmaya hazır hale gelmesi beklenmiștir. Hücrelerin çoğaltılması așamalarında \%10 FBS+ 2 mM Lglutamin,+ $100 \mathrm{IU} / \mathrm{ml}$ penisilin ve 100 $\mu \mathrm{g} / \mathrm{ml}$ streptomisin içeren MEM (PAA Laboratories, Austria) vasatı kullanılmıștır. Hücreler \%90 nem 
$37{ }^{\circ} \mathrm{C}$ 'de \%5 CO 'li inkübatörde (19AIC-UV, Sanyo) inkübe edilmiștir.

Nitel Değerlendirme: Hücreler altılı plakalara ekilerek inkübatöre konulmuș ve \%80 konfluense ulașması beklenmiștir. Daha sonra üzerlerine 1/1, $1 / 10,1 / 100$ ve $1 / 1000$ dilüsyonlarda hazırlanan sonda özütlerini derișimleri uygulanmıștır. 24 saat \%90 nemli, $37^{\circ} \mathrm{C}$ 'de \%5 $\mathrm{CO}_{2}$ 'li inkübatörde bekletildikten sonra hücreler mikroskopla incelenerek genel morfoloji, vokuolizasyon (boșluk olușması), hücre kalkması, hücre yıkımı ve membran bütünlüğündeki değișiklikler TS EN ISO 10993-5 standardında bulunan Tablo-1'e göre değerlendirilmiștir.

Nicel Değerlendirme (MTT Testi): MTT testi indirekt olarak hücre büyümesi ve/veya hücre ölümünü değerlendirmeyi amaçlayan, hücre kültürü esasına dayanan bir testtir (10). Deney için gerekli olan özüt dilüsyonları ve pozitif ve negatif kontrol, MTT (3-(4,5-dimetiltriazol-2-il)-2,5-difeniltetrazolium bromid) boyası, aynı gün hazırlanarak taze olarak kullanılmıștır. MTT (Sigma, Almanya), fenol kırmızısı içermeyen MEM içinde $1 \mathrm{mg} / \mathrm{ml}$ olacak șekilde çözülerek $0,22 \mu \mathrm{m}$ filtreden süzülmüștür.
MTT testi için, 96 kuyulu plaklara $100 \mu \mathrm{l}$ besiyeri içinde 104 hücre/kuyu olacak șekilde ekim yapılmıștır. 24 saat inkübe edilen hücreler üzerine özütler 1/1$1 / 128$ dilüsyonlar arasında hazırlanarak eklenmiș ve 24 saat daha $37^{\circ} \mathrm{C}$ 'de $\% 5 \mathrm{CO}_{2}$ 'li ortamda inkübasyona bırakılmıştır. Örnekler her ilaç konsantrasyonu için altı kuyu olarak çalıșılmıștır. Negatif kontrol olarak, aynı șartlarda özüt uygulanmamıș hücreler ve USP standart polietilen özütü $(0,2 \mathrm{~g} / \mathrm{mL})$, pozitif kontrol olarak ise $10 \mathrm{mMAmonyum} \mathrm{Molibdat} \mathrm{(Amonium}$ heptomolybdate-tetrahydrate, Merck) çözeltisi kullanılmıștır. 24 saat sonra özütler boșaltılarak hücrelerin üzerine $50 \mu \mathrm{MTT}$ eklenmiş ve iki saat inkübe edilmiștir. İnüubasyon sonrası kuyulardaki çözeltiler dökülüp her kuyucuğa $100 \mu \mathrm{l}$ isopropanol eklenmiş ve plakların spektrofotometrik olarak $570 \mathrm{~nm}$ (referans $650 \mathrm{~nm}$ )'de absorbans değerleri okunmuștur.

Sitotoksisiteyi değerlendirmeden önce, hücresiz kuyulardaki OD değerleri (sadece vasat + MTT), özütlerin bulunduğu kuyucukların OD değerlerinden çıkarılmıştır. Numunelerin toksisitesinin hesaplanmasında așağıdaki formül kullanılmıștır.

Tablo 1. Sonda özütlerin sitotoksisitesinin nitel morfolojik derecelendirilmesi

\begin{tabular}{|c|c|c|}
\hline Deney Grubu & Skor & Kültürrlerin durumları \\
\hline $\begin{array}{l}\text { USP Standart Polietilen } \\
\text { (Negatif Kontrol) }\end{array}$ & $\begin{array}{c}0 \\
\text { (Yok) }\end{array}$ & $\begin{array}{l}\text { Ayrık sitoplazma içi granüller, hücre yıkımı yok, hücre çoğalmasında } \\
\text { azalma yok }\end{array}$ \\
\hline$\% 100$ Silikon & $\begin{array}{c}1 \\
\text { (Çok az) }\end{array}$ & $\begin{array}{l}\text { Hücrelerin \%20'sinden daha fazlası yuvarlak olmayan, zayıf tutunmuș ve } \\
\text { sitoplazma içi granül içermeyen veya morfolojide değișiklikler gösteren, } \\
\text { nadiren yıkıma uğramıș hücreler var, sadece hafif büyüme inhibisyonu } \\
\text { gözlemlenebilir }\end{array}$ \\
\hline Silikon Kaplanan Kauçuk & 4 (Şiddetli) & Hücre katmanların tamamı veya tamamına yakını yıkıma uğramış \\
\hline Doğal Kauçuk & 4 (Şiddetli) & Hücre katmanların tamamı veya tamamına yakını yıkıma uğramıș \\
\hline $\begin{array}{l}\text { Doğal Kauçuk + EDTA ve } \\
\text { Silikon Kaplanan Kauçuk } \\
\text { + EDTA }\end{array}$ & $\begin{array}{c}1 \\
\text { (Çok az) }\end{array}$ & $\begin{array}{l}\text { Hücrelerin \%20'sinden daha fazlası yuvarlak olmayan, zayıf tutunmuş ve } \\
\text { sitoplazma içi granül içermeyen veya morfolojide değișiklikler gösteren, } \\
\text { nadiren yıkıma uğramıș hücreler var, sadece hafif büyüme inhibisyonu } \\
\text { gözlemlenebilir }\end{array}$ \\
\hline $\begin{array}{l}\text { AmonyumMolibdat } \\
(10 \mathrm{mM}) \text { (Pozitif Kontrol) }\end{array}$ & 4 (Şiddetli) & Hücre katmanların tamamı veya tamamına yakını yıkıma uğramıș \\
\hline
\end{tabular}

(TS EN ISO 10993-5 Temmuz 2010 standardında bulunan Tablo-1'e göre değerlendirilmiștir). 
$\%$ canlılık $=100 \times$ Her bir numunenin bulunduğu kuyucukların ortalama OD değeri Negatif kontrol kuyucuklarının Ortalama OD değeri

Alevli Atomik Absorbsiyon Yöntemi: Bu araștırmada, özütler içeriğinde bulunan elementlerin miktar tayini için Alevli Atomik Absorpsiyon Spektrofotometresi (AAS) yöntemi uygulanmıștır. Krom $(\mathrm{Cr})$, Gümüș $(\mathrm{Ag})$, Bakır $(\mathrm{Cu})$, Bizmut $(\mathrm{Bi})$, Kurșun $(\mathrm{Pb})$, Demir $(\mathrm{Fe})$, Kobalt $(\mathrm{Co})$, Kadmiyum (Cd) ve Çinko $(\mathrm{Zn})$ elementlerinin her biri için, istenilen dalga boyunda ıșın yayan uygun "Oyuk Katot Lambası" kullanılmıștır. Yanıcı ve yakıcı gazlar, analizi yapılacak elementin atomlașma sıcaklığına göre seçilmiștir. Her element için uygun konsantrasyonlarda hazırlanan standart çözeltiden yararlanarak standart eğrisi

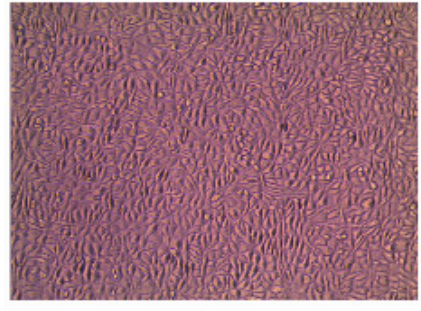

(a)

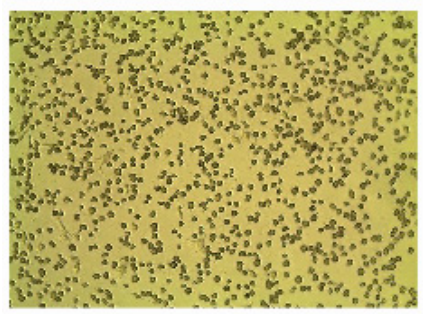

(b)

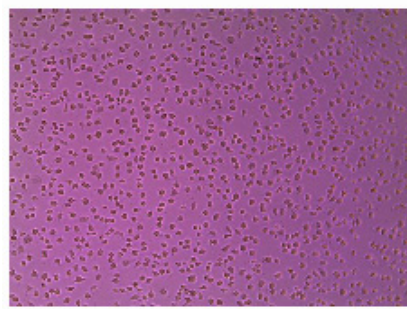

(c) çizilmesini takiben sonda özütlerinin absorbans değeri okutularak elementin numune içerisindeki konsantrasyonu hesaplanmıștır.

İstatistiksel Yöntem: Elde edilen bulgular; ortalama \pm standart hata olarak ifade edilmiștir. Gruplar arasındaki farklar, "Kruskal Wallis H" ve "Mann-Whitney U" testleri ile değerlendirilmiștir. Anlamlılık sınırı $\mathrm{p}<0,05$ olarak kabul edilmiştir.

\section{BULGULAR}

L-929 hücrelerinin özütler ile 24 saat, $37{ }^{\circ} \mathrm{C}$, $\% 5 \quad \mathrm{CO}_{2}^{\prime} l i$ ortam șartlarında inkübe edilmesi sonrasında ortaya çıkan mikroskopik değișiklikler nitel değerlendirme ile ortaya konmuștur. Şekil 1, (c) ve (d) fotoğraflarında görüldüğü gibi doğal kauçuk

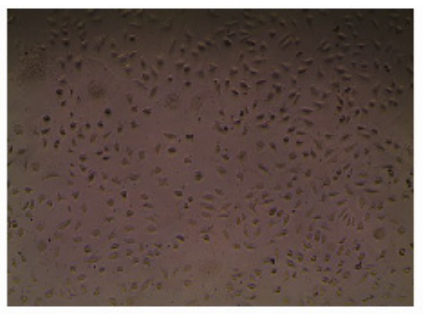

(d)
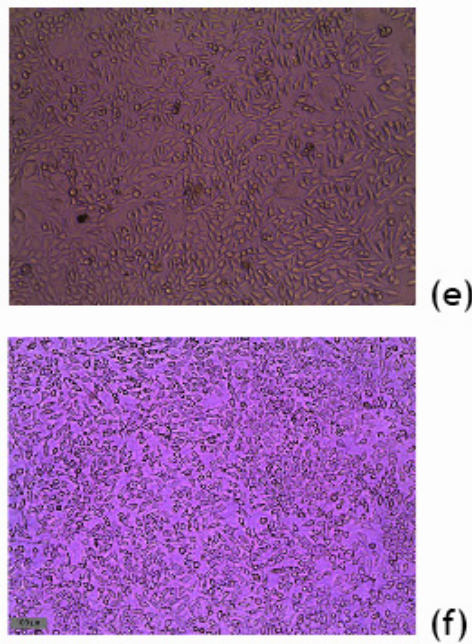

(f)

Şekil 1. Sonda özütlerine $37{ }^{\circ} \mathrm{C}, \% 5 \mathrm{CO}_{2}$ 'li ortam șartlarında 24 saat boyunca maruz kalan L-929 hücrelerinde görülen mikroskopik etkiler (LEICA DFC295 FIREWIRE görüntüleme sistemli mikroskop- 10x büyütme). Negatif kontrol olarak kullanılan USP standart polietilen (a) ve silikon yapıda sonda (e) özütlerine maruz kalan fibroblast hücrelerinde mikroskopik olarak herhangi bir değișiklik görülmezken pozitif kontrol örneği (Amonyum Molibdat 10 mM) (b), doğal kauçuk (c) ve silikon kaplanan kauçuk (d) sondaların özütü ile inkübe edilen hücrelerde yuvarlaklașma, konflüens kaybı, ayrılma gibi toksisite belirtileri gözlenmiștir. Bu toksik etkilerin özütlere $5 \mu \mathrm{M}$ Na-EDTA eklenmesi ile tümüyle geri dönmüștür (f). 
ve silikon kaplanan kauçuk sondalarda, özütlerin uygulanması sonrası hücreler negatif kontrol numunesinde görülen paternlerini değiștirmișler, sitoplazmik kayba uğrayarak tanecikler halinde kümelenmișlerdir. Hücreler arasında geniș boșluklar, hücre membran lizisi ve hücre yıkımı dikkati çekmiștir. Geniș alanlardaki boșluklar, hücrelerin canlılığını kaybederek yüzeyden kalktığını göstermiștir. Silikon sonda örneklerinde ise yuvarlak hücre oranının \%20'den daha az olduğu, hücrelerin sitoplazma içi granül içermediği ve morfolojik değișiklikler görülmediği, sadece hücre büyümesinde hafif inhibisyon olduğu dikkati çekmiștir. Özütlere uygulama öncesinde $5 \mu \mathrm{M}$ Na-EDTA eklenmesi ile sitotoksik etkilerin ortadan kalktığı ve hücrelerin canlılıklarını koruduğu fark edilmiștir (f). Bu nitel değerlendirmeler TS EN ISO 10993-5 Temmuz 2010 standardına göre skorlandığında ortaya çıkan bulgular Tablo 1'de özetlenmiștir.

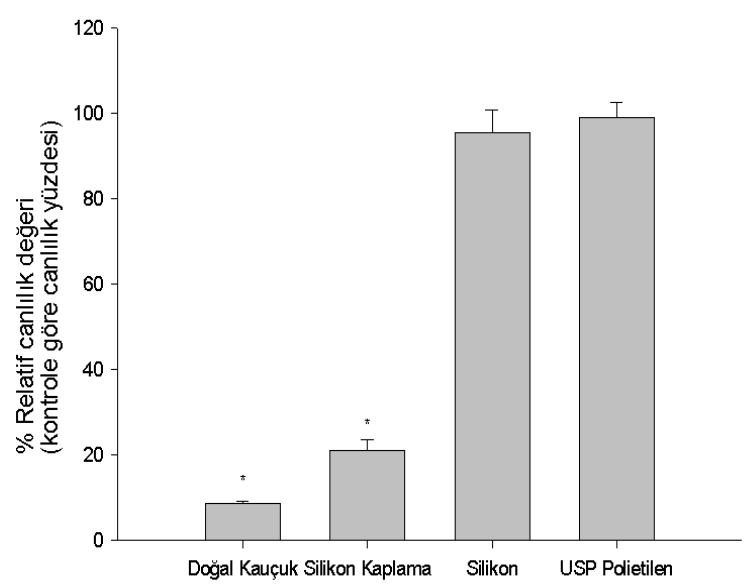

Şekil 2. Değișik yapısal özelliklerdeki sondalardan elde edilen özütlerin L-929 fibroblast hücre canlılığı üzerine olan etkileri: Hücrelerin, üç farklı yapısal grup sondadan elde edile özütlere, 24 saat, $37{ }^{\circ} \mathrm{C}, \% 5 \mathrm{CO}_{2}$ 'li ortam șartlarında maruz bırakılması sonrasında, negatif kontrol olarak kullanılan USP standart polietilenin $(\% 98,97 \pm 3,49)$ ve silikon yapıdaki $(\% 95,43 \pm 5,39)$ sondaların hücre canlılığına herhangi bir etkisi olmadığı ancak doğal kauçuk $(\% 8,57 \pm 0,54)$ ve silikon kaplı doğal kauçuk $(\% 21,0 \pm 2,52)$ yapıdaki sondalarda canlılık değerlerinin anlamlı olarak azaldığı gözlenmiștir ( ${ }^{*} \mathrm{p}<0,01$, $n=6$ ).
Sonda özütlerinin L-929 fare bağ doku fibroblast hücrelerinin canlılıkları üzerine olan etkileri Şekil 2' de gösterilmiștir. Hücrelerin, üç farklı yapısal grup sondadan elde edilen özütlere, 24 saat, $37^{\circ} \mathrm{C}, \% 5 \mathrm{CO}_{2}$ 'li ortam șartlarında maruz bırakılması sonrasında, negatif kontrol olarak kullanılan USP standart polietilenin $(\% 98,97 \pm 3,49)$ ve silikon yapıdaki $(\% 95,43 \pm 5,39)$ sondaların hücre canlılığına herhangi bir etkisi olmadığı ancak doğal kauçuk ve silikon kaplı doğal kauçuk yapıdaki sondalarda (sırasıyla \%8,57 $\pm 0,54$ ve $\% 21,0 \pm 2,52)$ canlılık değerlerinin anlamlı olarak azaldığı gözlenmiștir $(p<0,01, n=6)$.

Doğal kauçuk sondaların toksik etkisi, Silikon ile kaplanan kauçuk sondalara göre anlamlı olarak yüksek bulunmuștur $(p<0,01)$. Silikon kaplı ve doğal kauçuk sondalardan elde edilen özütlerin \%50 inhibisyon yapan konsantrasyon (IC50) değerleri ise sırasılyla $0,16 \pm 0,01$ ve 0,05 $\pm 0,001$ olarak hesaplanmıștır. Buna ek olarak farklı markalardaki silikon kaplı sondalar arasında sitotoksisite oranları açısından anlamlı farkların bulunduğu da görülmüștür (Șekil 3).

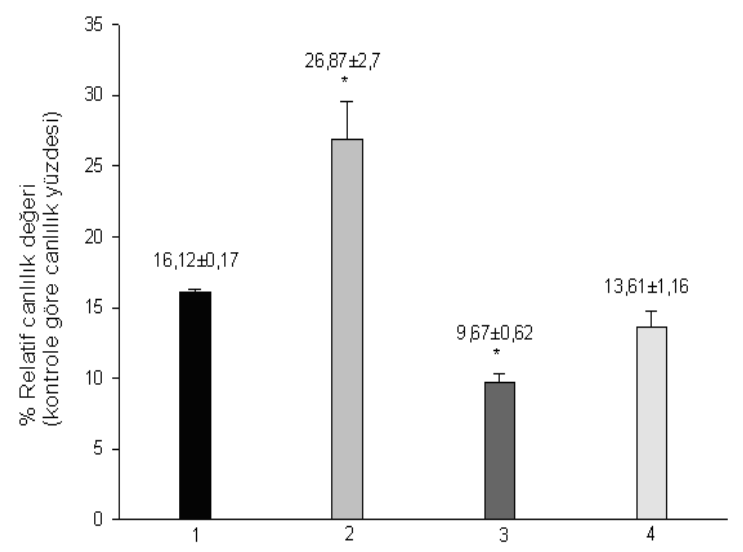

Şekil 3. Farklı marka silikon kaplama sonda özütlerinin L-929 hücre canlılığı üzerine olan etkileri: Hücreler, dört farklı marka silikon kaplı kauçuk sondadan elde edile özütlere, 24 saat, $37^{\circ} \mathrm{C}, \% 5 \mathrm{CO}_{2}^{\prime}$ 'li ortam şartlarında maruz bırakılmış ve hücre canlılığı üzerindeki etkiler araștırılmıștır. Aynı yapıda olsa da farklı sonda markalarının sitotoksik etkileri arasında anlamlı farkların bulunduğu dikkati çekmektedir. $\left({ }^{*} p<0,05, n=6\right)$. 
Sonda özütleri içeriğinde bulunan elementlerin analiz sonuçları Şekil 4'de özetlenmiștir. Özütlerdeki $\mathrm{Cr}, \mathrm{Co}, \mathrm{Cd}, \mathrm{Ag}$ ve $\mathrm{Cu}$ değerleri AAS yönteminin deteksiyon limitlerinin altında bulunmuștur. Konsantrasyonları değerlendirilebilinen $\mathrm{Bi}, \mathrm{Pb}$ ve $\mathrm{Fe}$ elementlerinin düzeyleri bakımından sonda özütleri ile kontrol olarak kullanılan vasat arasında fark bulunmamıștır. Ancak kauçuk yapıdaki sondalardan elde edilen özütlerdeki $\mathrm{Zn}$ düzeylerinin, vasattan $(0,13 \pm 0,03 \mathrm{mg} / \mathrm{L})$ ve silikon sondalardan $(0,12 \pm$ $0,01 \mathrm{mg} / \mathrm{L}$ ) anlamlı olarak yüksek olduğu gözlenmiștir $\left({ }^{*} p<0,01, n=6\right)$.

AAS yöntemi ile elde edilen sonuçlar, kauçuk yapıdaki sonda özütlerinde yüksek düzeyde bulunan Zn oranlarının, ortaya çıkan sitotoksisiteden sorumlu olabileceğini göstermiștir. Bu bulguyu desteklemek amacıyla birçok metodolojide metal

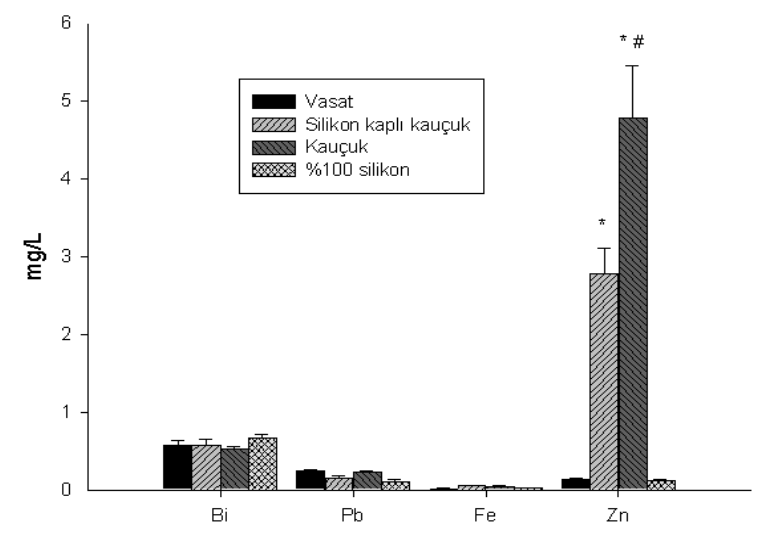

Şekil 4. Atomik Absorbsiyon Spektrofotemetresi(AAS) yöntemi ile sonda özütlerinin elementer analizi: Araștırılan elementer içerisinde bulunan $\mathrm{Cr}, \mathrm{Ag}, \mathrm{Cu}, \mathrm{Co}$ ve Cd'nin özütlerdeki düzeyleri yöntemin deteksiyon limitlerinin altında olduğundan gösterilmemiștir. Konsantrasyonları değerlendirilebilinen $\mathrm{Bi}, \mathrm{Pb}$, Fe elementlerinin kontrol olarak kullanılan vasat ile sonda özütleri arasında fark bulunmamıștır. Kauçuk yapıdaki sondalardan elde edilen özütlerin Zn düzeyleri, vasattan $(0,13$ $\pm 0,03 \mathrm{mg} / \mathrm{L})$ ve silikon sondalardan $(0,12 \pm 0,01 \mathrm{mg} / \mathrm{L})$ anlaml olarak yüksek olduğu gözlenmiștir (* $\mathrm{p}<0,01, \mathrm{n}=6)$. Ek olarak, Doğal kauçuk sondalarda $(4,8 \pm 0,66 \mathrm{mg} / \mathrm{L})$ bulunan $\mathrm{Zn}$ değerleri Silikon kaplı doğal kauçuk sondalardaki değerlerden $(2,8 \pm 0,34$ $\mathrm{mg} / \mathrm{L}$ ) anlamlı olarak yüksek bulunmuștur (\# $\mathrm{p}<0,05, \mathrm{n}=6$ ). iyonlarının eliminasyonunda kullanılan bir şelatör olan etilendiamintetraasetik asit (EDTA)'in hücre canlılığı üzerine etkisi araștırılmıştır. 0,1 - 500 $\mu \mathrm{M}$ arasındaki EDTA konsantrasyonları L-929 hücreleri üzerine uygulanan MEM vasatına katılarak MTT testi uygulanmıștır. Elde edilen sonuçlar, $5 \mu \mathrm{M}$ düzeyinde eklenen Na-EDTA, hücre yașayabilirliğini değiștirmemiștir (\%100,24 $\pm 4,91)$. Bu bulgu literatürde, sıçan böbrek hücre kültüründe Na-EDTA maruziyetini inceleyen bir araștırma sonuçları ile uyumludur (11). Sondaların özüt alma işleminde kullanılan MEM hücre vasatına, özütleme sonrasında $5 \mu \mathrm{M} \mathrm{Na-EDTA} \mathrm{eklenerek}$ hücrelere uygulanmış ve 24 saat sonra MTT testi ile canlılık oranları değerlendirilmiştir. Kauçuk sondalar ile ortaya çıkan sitotoksisitenin EDTA varlığındaki değişimi Şekil 5'de görülmektedir. Sonuçlar; kauçuk ile iliş̧ili olduğu düşünülen toksik etkilerin, Na-EDTA $(5 \mu M)$ varlığında anlamlı olarak geri döndüğünü göstermiștir ( $\left.{ }^{*} p<0,01, n=6\right)$.

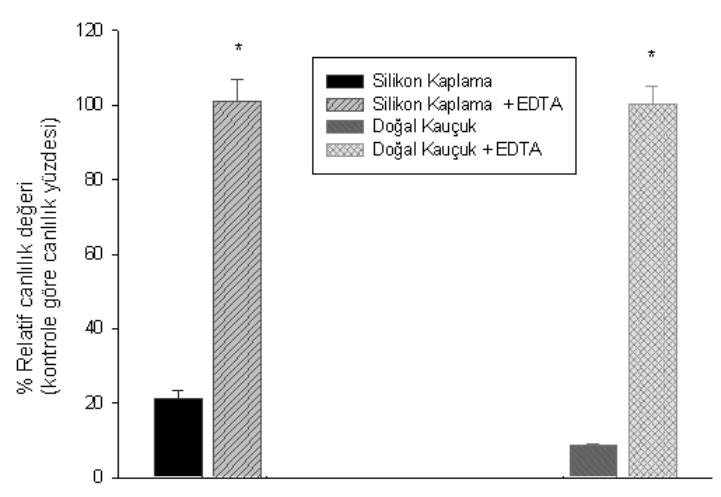

Şekil 5. Doğal Kauçuk ve Silikon kaplı sondalardan elde edilen özütlerin sitotoksik etkilerinin EDTA $(5 \mu M)$ varlığında değișimi: Hücre özütlerinin alındığı MEM hücre vasatına, özütleme ișlemi sonrasında $5 \mu \mathrm{M} \mathrm{Na-EDTA}$ eklendiğinde canlılık düzeyinde ortaya çıkan değișim MTT testi ile ortaya konmuștur. Hücrelerin doğal kauçuk $(\% 8,57 \pm 0,54)$ ve silikon kaplı doğal kauçuk $(\% 21,0 \pm$ 2,52 ) yapıdaki sondalarda ortaya çıkan canlılık değerlerinin, ortama 5 $\mathrm{M}$ Na-EDTA eklenmesi ile anlamlı olarak artarak negatif kontrol düzeylerine çıktığı (sırasıyla \%101,05 \pm 5,86 ve $100,24 \pm 4,9)$ gözlenmiștir ( $\left.{ }^{*} p<0,01, n=6\right)$. 


\section{TARTIŞMA}

Foley kateterlerin ilk kullanıldığı yıllardan bu yana enfeksiyon yada tıkanma gibi problemlere neden olduğu bilinmektedir. Bu sorunların çözümü için yapısal değișikliklerin, farklı koruyucuların, anti bakteriyel ajanların veya hidrojel, gümüș, teflon, silikon gibi kaplamaların uygulanması denenmiștir. Toplumlarda yașlı hasta sayısının giderek artması, uzun süreli idrar sondası uygulanması gereken kalp damar cerrahisi veya serebrovasküler olayların insidansının artıșını da birlikte getirmiștir. Buna bağlı olarak da, üriner kateterizasyon ile ilișkilendirilen komplikasyonların olası nedenleri ve çözüm yolları daha büyük bir önem kazanmıștır. Bu çözüm yollarının birbirlerine olan üstünlüğü halen tartıșılmakta ve tedavi maliyet analizlerine olan etkisi karșılaștırılarak kiși ve duruma özgü öneriler olușturulmaya çalıșılmaktadır.

Kateter üretiminde kullanılan materyallerin klinikte görülen komplikasyonlardan sorumlu olabileceğine yönelik șüphelerin ortaya konduğu ilk günden itibaren yapılan çalıșmalarda, kauçuk sondaların etkileri in vivo ve in vitro olarak araștırılmaktadır. Bu çalıșmaların birçoğunda doğal kauçuk yapıda sondaların diğer sondalara oranla uygulandığı hastalarda daha çok komplikasyona yol açtığı ve toksik etkiler gösterdiği rapor edilmiștir (12-14). Bizim bulgularımız da bu yönüyle literatür ile uyumludur. Buna karșın Engelbart ve ark. tarafından köpeklerde yapılan bir çalıșmada, silikon ve kauçuk yapıda altı farklı grup kateterin, dokudaki inflamasyon üzerine etkileri araștırılmıștır. Sondalar altı hafta süre ile uygulandıkdan sonra, doku cevapları incelenmiș, silikon ve kauçuk gruplar arasında anlamlı bir fark olmadığı iddia edilmiștir (15). Ancak bu çalıșmada ilk 24 saat içerisinde inceleme yapılmadığından bizim çalıșmamızda ilk 24 saat sonrası kauçuk sondalarda gözlemlediğimiz toksik etkilerin gözden kaçırıldığı açıktır. Graham ve arkadașları tarafından uygulanan, hücre kültürü, tavșan kas implantasyonu ve fare sistemik toksisite deneylerinde ise, kauçuk sondalardan salıverilen bazı zararlı maddelerin üretrit veya darlık gibi klinik sonuçlara yol açabilecek toksisite gösterdiği rapor edilmiștir (16). Aynı çalıșmada, hücre kültürü metotlarının, hayvan denekler kullanılan in vivo testlere göre çok daha hassas olduğunu belirtilmiș ve diğer araștırmacılar tarafından da desteklenmiștir $(14,17)$. Örneğin tavsan primer üreter epiteli (18) ya da insan üreter epiteli (19) gibi hücre kültürü teknikleri ile yapılan araștırmalarda, kauçuk sondaların toksik etkileri gösterilmiștir. Benzer sonuçlar doğal kauçuktan yapılan cerrahi eldivenlerin özütleri ile yapılan hücre kültürü çalıșmaları ile desteklenmiștir (20).

Doğal kauçuk hammaddesinden idrar sondası üretimi așamaları sırasında sertlik, esneklik, gerim direnci, yoğunluk v.b. özelliklerinin geliștirilmesi için birçok kimyasal madde ile muamele edilmekte, daha sonra yüzey geriliminin, bakteri adezyonunun veya toksisitesinin azaltılması amacıyla kaplanmaktadır. Bu maddeler (stabilizatörler, boyalar, tepkime hızlandırıcılar vs.) içinde hangilerinin, ne oranda bulunduğu endüstiyel bir sırdır.

Çalıșmamızda, \%100 silikon yapıda sondaların toksik olmadığı, silikon kaplanan kauçuk sondalarda görülen toksisitenin doğal kauçuk sondalara göre anlamlı olarak $(p<0,01)$ azaldığı ancak buna rağmen uygun kabul edilen sınırdan (\%70) oldukça düşük olduğu gözlenmiștir. Buna ek olarak silikonize kauçuk sonda grupları arasında da toksisite açsından fark olması dikkat çekicidir. AAS çalışmalarımızın sonuçları, kauçuk ve silikonize kauçuk sondalardan özütleme sırasında süzülerek hücreler üzerinde toksik etkiye sebep olabilecek etkenin, çinko olabileceğini göstermiștir. Kauçuk yapıdaki sondalardaki Zn miktarı, toksisite ile uyumlu olarak daha yüksektir. Metal iyonlarının EDTA ile bağlanması ile sitotoksisitenin tamamen geri dönmesi, toksik etkinin yüksek $\mathrm{Zn}$ düzeylerinden kaynaklandığı hipotezimizi desteklemiștir. Çinko, doğal kauçuğun kükürt ile ișlenmesi așamasında kullanılan önemli bir elementtir. Büyük bölümü çinko oksit ( $\mathrm{ZnO})$ șeklinde kullanılmaktadır. Bunun yanında üretimde 
tepkime hızlandırıcı olarak kullanılan birçok kimyasal içerisinde de çinko bulunmaktadır. Çinko oksit ve diğer birçok çinko türevinin sitotoksik ve karsinojenik etkiler gösterdiği daha önce de rapor edilmiștir $(21,22)$.

Kauçuk sondalar ile ortaya çıkan toksisitenin azaltılması amacıyla silikon ile kaplanmasının, toksik etkiyi azaltmasına rağmen önleyemediği görülmüștür. Bunun nedeninin kaplama süreci sırasında kullanılan Zn değeri yüksek kimyasallar olduğu düșünülmektedir. $\mathrm{Bu}$ nedenle üretim așamasında kullanılan kimyasallardaki çinko oranlarının azaltılması toksisite için faydalı olabilir. Silikonize kauçuk yapıdaki sonda grupları arasında gözlemlenen farklı toksisite oranlarının, üretim kalitelerindeki değișikliklerden kaynaklanabileceği düșünülmüștür. Bu görüș, silikon, hidrojel, teflon gibi kaplama metodolojileri kullanılarak kaplanan kauçuk sondaların iç ve dıș yüzeylerinin SEM (Scannig Electron Microscopy) ile incelendiği bir çalıșma ile desteklenmektedir (23). $\mathrm{Bu}$ çalışmada incelenen sondalar arasında, farklı üreticilerin uyguladığı kaplamalar arasında anlamlı farklar bulunduğu gösterilmiștir.

İdrar sondalarındaki toksik etkilerin nedenleri üzerine yapılan bașka çalıșmalar da bulunmaktadır.
Bizim çalıșmamızda olduğu gibi L-929 fibroblastik seri hücreleri üzerinde yapılan bir araștırmada, kauçuk sondalarda görülen toksisiteden, yapılarından salınan $\mathrm{N}$-nitrosaminler sorumlu tutulmuștur (24). $\mathrm{N}$-nitrozodi-N-butilamin ve $\mathrm{N}$-nitrozodietilamin düzeylerindeki yükseklik hücrelerdeki toksisite oranları ile ilișkili bulunmuștur. Bu maddelerin doğal kauçuktan sonda üretim aşamasında hızlandırıcı olarak kullanıldığı bilinmektedir.

Günümüzde idrar sondaları ayaktan ve yatan hastalarda sıklıkla kullanılan tıbbi cihazlardır. Şu anda ülkemizde kullanılan sondaların (özellikle kauçuk sondalar) neden olduğu komplikasyonların ortaya çıkardığı ek tedavi maliyetlerini ortaya koyan ayrıntılı bir çalıșma bulunmamaktadır. $\mathrm{Bu}$ önemli sorunun așilabilmesi için üriner kateterizasyon amacıyla kullanılan kauçuk yapıdaki idrar sondalarının üretim așamalarının gözden geçirilmesi, iyileștirilmesi, piyasa gözetim ve denetimleri ile kalitelerinin izlenmesi önemli adımlardır. Bu şekilde toksik olmayan ve güvenle kullanılabilecek sondaların tedavide yer bulmaları mümkün olacaktır.

\section{KAYNAKLAR}

1. Elves AW, Feneley RC. Long-term urethral catheterization and the urine-biomaterial interface. Br J Urol. 1997; 80(1): 1-5.

2. Winson L. Catheterization: A need for improved patient management. Br J Nurs. 1997; 10; 6(21): 1229-32.

3. Evans A, Pheby D, Painter D, Feneley R. The costs of long-term catheterization in the community. $\mathrm{Br}$ J Community Nurs. 2000; 5(10): 477-8.

4. Morris NS, Stickler DJ, McLean RJ. The development of bacterial biofilms on indwelling urethral catheters. World J Urol. 1999;17(6): 345-50.
5. Lawrence EL, Turner IG. Materials for urinary catheters: a review of their history and development in the UK. Med Eng Phys. 2005; 27(6): 443-53.

6. Hunt LW, Kelkar P, Reed CE, Yunginger JW. Management of occupational allergy to natural rubber latex in a medical center: the importance of quantitative latex allergen measurement and objective follow-up. J Allergy Clin Immunol. 2002; 110(2 Suppl): S96-106.

7. Kowalczuk D, Ginalska G, Przekora A. The cytotoxicity assessment of the novel latex urinary catheter with prolonged antimicrobial activity. J Biomed Mater Res A. 2011; 98(2): 222-8. 
8. TS EN ISO 10993- 12 “Tıbbi Cihazların Biyolojik Değerlendirilmesi: Bölüm 12; Numune Hazırlama ve Referans Malzemeler. Mart 2010".

9. TS EN ISO 10993-5 "Tıbbi Cihazların Biyolojik Değerlendirilmesi: Bölüm 5- Vücut dıșı sitotoksisite deneyleri. Temmuz 2010".

10. Mossman T. Rapid colorimetric assay for cellular growth and survival: application to proliferation and cytotoxicity assay. J Immunol Method, 1983; 65: 55-63.

11. Hugenschmidt S, Planas-Bohne F, Taylor DM. On the toxicity of low doses of tetrasodiumethylenediamine-tetraacetate (Na-EDTA) in normal rat kidney (NRK) cells in culture. Arch Toxicol, 1993; 67(1): 76-8.

12. Graham DT, Mark GE, Pomeroy AR. Cellular toxicity of urinary catheters. Med J Aust, 1983; 14; 1(10): 456-9.

13. Bruce AW, Plumpton KJ, Willett WS, Chadwick P. Urethral response to latex and Silastic catheters. Can Med Assoc J, 1976; 115(11): 1099-100.

14. Ruutu M, Alfthan O, Talja M, Andersson LC. Cytotoxicity of latex urinary catheters. Br J Urol, 1985; 57(1): 82-7.

15. Engelbart RH, Bartone FF, Gardner P, Hutson J. Urethral reaction to catheter materials in dogs. Invest Urol, 1978;16(1): 55-6.

16. Graham DT, Mark GE, Pomeroy AR, Macarthur EB. In vivo validation of a cell culture test for biocompatibility testing of urinary catheters. J Biomed Mater Res, 1984; 18(9): 1125-35.
17. Talja M, Andersson LC, Ruutu M, Alfthan O. Toxicity testing of urinary catheters. Br J Urol. 1985; 57(5): 579-84.

18. Drewa T, Wolski Z, Gatazka P, Wozniak A, Olszewska-Stonina D, Sir J. [Silicone and latex urinary catheters cytotoxicity on primary cultured rabbit urothelial cells]. Pol Merkur Lekarski. 2004; 16(93): 228-31.

19. Pariente JL, Bordenave L, Jacob F, Bareille R, Baquey C, Le Guillou M. Cytotoxicity assessment of latex urinary catheters on cultured human urothelial cells. Eur Urol. 2000; 38(5): 640-3.

20. Baek HS, Yoo JY, Rah DK, Han DW, Lee DH, Kwon $\mathrm{OH}$, et al. Evaluation of the extraction method for the cytotoxicity testing of latex gloves. Yonsei Med J, 2005; 31; 46(4): 579-83.

21. Talja M, Saarela K, Ruutu M, Andersson LC, Alfthan 0 . Zinc compounds in urethral catheters. A possible source of toxicity? Ann Chir Gynaecol Suppl, 1993; 206: 74-9.

22. Borovanský J, Riley PA. Cytotoxicity of zinc in vitro. Chem Biol Interact, 1989; 69(2-3): 279-91.

23. Lawrence EL, Turner IG. Characterisation of the internal and external surfaces of four types of Foley catheter using SEM and profilometry. J Mater Sci Mater Med, 2006; 17(12): 1421-31.

24. Heenan MP, Nacey JN, Delahunt B, Ferguson AF, Dickson SJ. Volatile $\mathrm{N}$-nitrosamines in urinary catheters. Br J Urol, 1989; 63(1): 72-5. 


\title{
Konya ilinde köpeklerde listeriozis seroprevalansı
}

\section{The seroprevalence of canine listeriosis in dogs in Konya province}

\author{
Zeki ARAS', $\quad$ Uçkun Sait UÇAN²
}

\section{ÖZET}

Amaç: Listeriozis, insan ve hayvanlarda abortus, septisemi ve meningoensefalitise sebep olmaktadır. Enfekte köpekler Listeria monocytogenes sușlarını dıșkı ve idrarları ile etrafa saçtıkları için halk sağlığı yönünden büyük bir öneme sahiptirler. Bu çalıșmada, Konya bölgesindeki köpeklerde listeriozis enfeksiyonunun serolojik yöntemlerle araștırılması amaçlanmıștır.

Yöntem: Çalıșmanın köpek materyalini Konya il merkezinde bulunan belediye köpek barınağı $(n=106)$ ve Selçuk Üniversitesi Veteriner Fakültesi (SÜVF) Köpekçilik Araștırma ve Uygulama Ünitesinde bulunan köpekler $(n=20)$ ile süVF Kliniklerine getirilen köpeklerden $(n=9)$ alınan toplam 135 kan serumu olușturmuștur. Serumlar Mikro Standart Tüp Aglütinasyon (mSAT) ve ELISA testleri ile incelenmiștir. Guruplar arası karșılaștırmalar Mc Nemar Testi ve Fisherin Kesin $x^{2}$ testi ile belirlenmiștir.

Bulgular: Toplam 135 kan serum örneğinin 31 (\%23)'i mSAT ile ve $21(\% 15,5)$ 'i ELISA ile pozitif bulunmuștur. On dört serum örneği sadece mSAT testi ile pozitif bulunurken ELISA testi ile negatif olarak bulunmuștur. Kan serum örneklerinin 114 tanesi $(\% 84,5)$ ELISA testi ile negatif olarak bulunmuștur. Listeriozisin serolojik sıklığı Konya Belediye Köpek Barınağı, SÜVF Köpekçilik Araștırma ve Uygulama Ünitesi ve SÜVF kliniklerine getirilen köpekler

\section{ABSTRACT}

Objective: Listeriosis causes abortion, septicemia and meningoencephalitis in humans and animals. Infected dogs are important in public health as they can spread Listeria monocytogenes strains via their faeces or urine. The aim of this study was to investigate the presence of listeriosis in dogs in Konya Province.

Method: A total of 135 blood serum samples were collected from dogs from the municipality kennels $(\mathrm{n}=$ 106) and also from veterinary clinics $(n=9)$ and the Dog Research Unit $(n=20)$ of the Faculty of Veterinary Medicine, Selcuk University. Samples were examined by Micro Standard Tube Agglutination Test (mSAT) and ELISA. The statistical differences between the groups were determined by the Mc Nemar Test and Fisher Exact $\mathrm{x}^{2}$ Test.

Results: Out of 135 serum samples tested, 31 (23\%) and $21(15.5 \%)$ were found to be positive for listeriosis by mSAT and ELISA, respectively. Fourteen serum samples which were positive by mSAT were negative with ELISA, while 114 samples (84.5\%) were negative by ELISA. The frequencies of listeriosis in municipality kennels, the veterinary clinics and dog research unit of the Veterinary Faculty were $24.5 \%$,

' Konya IIl Sağlık Müdürlüğü, Selçuklu, KONYA

${ }^{2}$ Selçuk Üniversitesi, Veteriner Fakültesi, Mikrobiyoloji Anabilin Dalı, KONYA

İletisism/ Corresponding Author : Zeki ARAS

Konya Ill Sağık Müdürlüğü, 42 040, Selçuklu, KONYA Geliş Tarihi / Received : 25.11.2011

Tel : +903323511832_E-posta/E-mail : zekiaras@hotmail.com Kabul Tarihi / Accepted : 15.02 .2012

DOI ID : 10.5505/TurkHijyen.2012.82584

Aras Z, Uçan US. Konya ilinde köpeklerde listeriozis seroprevalansı. Turk Hij Den Biyol Derg, 2012; 69(1): 31-6. 
için sırasıyla, mSAT testi ile $\% 24,5, \% 11,1$ ve $\% 20$, ELISA testi ile $\% 19,8$, \%0 ve \%0 olarak belirlenmiștir. ELISA testi sonuçlarına göre, belediye köpek barınağında bulunan köpeklerde enfeksiyonun seroprevalansı Veteriner Fakültesinin birimlerine getirilen veya oraya ait köpeklere göre daha yüksek olarak saptanmıștır.

Sonuç: Bu çalıșma ile Konya bölgesi sokak köpeklerinde yüksek sayılabilecek bir oranda ve ilk kez L. monocytogenes seropozitifliği tespit edilmiștir. Bu yüksek oranın veteriner ve halk sağlığı açısından tehdit oluşturduğu kanısına varıımıștır.

Anahtar Sözcükler: Köpek, Listeria monocytogenes, ELISA, mSAT, halk sağlığı
$11.1 \%$ and $20 \%$, respectively by mSAT and $19.8 \%$, $0 \%$ and $0 \%$ by ELISA, respectively. According to ELISA results, the listeriosis frequency was found higher in dogs from the municipality kennels than in animals from the veterinary clinics or in dogs of the research unit of veterinary Faculty.

Conclusions: The present study shows that the seropositivity to $L$. monocytogenes in stray dogs from Konya is high and it is of concern for the veterinary and human public health.

Key Words: ELISA, dog, Listeria monocytogenes, mSAT, Public Health.

\section{GíRiş}

Listeria monocytogenes tarafından olușturulan listeriozis, genellikle sporadik, zaman zaman enzootik olarak ortaya çıkan, meningoensefalitis, abortus, septisemi ya da konjuktivitis ile karakterize, bazen de latent olarak seyredebilen zoonoz bir enfeksiyondur (1). Enfeksiyon, dünyanın her bölgesinde görülebilmektedir. Etken doğada çok yaygın olarak bulunur ve birçok hayvan türünden izole edilmiștir. L. monocytogenes, klinik veya subklinik seyirli enfeksiyona sebep olabilen, enfekte hayvanların dışkıları ile çevreyi kontamine eden ve direkt temas yolu ile diğer hayvan ve insanlara bulașabilen enfeksiyöz bir etkendir $(1,2)$.

Enfeksiyonun tanısında, etken izolasyon ve identifikasyonuna dayanan kültür yöntemi altın standart olarak kabul edilmektedir. Bu yöntemin uzun zaman almasından dolayı moleküler ve serolojik testler de sıklıkla kullanılır (3). Serolojik testlerden kompleman fiksasyon, indirekt hemaglutinasyon, agar jel difüzyon, serum aglütinasyon ve ELISA testleri hastaları ve portörleri ortaya koymak amacıyla kullanılmaktadır $(3,4)$. Bu yöntemlerin dışında, L. monocytogenes'in hızlı tespiti için, immünokromatografi, immünofloresans ve immüno manyetik ayırım yöntemlerinden de yararlanılmaktadır (5).

Mikroorganizmaların, enfekte veya portör hayvanların dișkıları ile etrafa saçılması ve enfeksiyonun zoonoz bir karakter sergilemesi nedeniyle sokak köpekleri halk sağlığı açısından ayrı bir öneme sahiptir. Yapılan çalıșmalarda, Van, Şanlıurfa, Erzurum ve Kars yörelerinde yașayan sokak köpeklerinde L.monocytogenes varlığı gösterilmiștir (4,6-8). Ülkemizdeki köpeklerin L. monocytogenes tașıyıcılığı ile ilgili sınırlı sayıda çalıșma bulunmasından dolayı; bu çalıșmada, ELISA ve Mikro Standart Tüp Aglütinasyon (mSAT) testleri kullanılarak, Konya bölgesindeki köpeklerde listeriozis varlığının araștırılması amaçlanmıștır.

\section{GEREÇ VE YÖNTEM}

Çalıșmada, Konya il merkezinde ki belediye köpek barınağında bulunan 106 (76 diși, 30 erkek) köpek ile Selçuk Üniversitesi Veteriner Fakültesi (SÜVF) Köpekçilik Araștırma ve Uygulama Ünitesinde bulunan 20 diși ve SÜVF Kliniklerine așılama için getirilen 9 (1 diși, 8 erkek) köpekten 2007 yılı içerisinde alınan toplam 135 adet kan serumu kullanılmıştır. Kan 
örnekleri klinik olarak sağlıklı görünen hayvanlardan rastgele olarak toplanmıs ve 1000 devirde 10 dakika santrifüj edilerek serumları ayrılmıștır. Toplanan kan serumları $56^{\circ} \mathrm{C}$ 'de 30 dakika tutularak inaktive edilip, kullanılıncaya kadar $-20{ }^{\circ} \mathrm{C}$ 'de muhafaza edilmiștir. Araştırma Selçuk Üniversitesi Veteriner Fakültesi Etik Kurulu tarafından onaylanmıştır.

Toplanan serumların mSAT testi ile titre tayini yapılmış ve en yüksek titre veren serum $(1 / 2560)$ pozitif kontrol olarak ELISA testinde kullanılmıștır. Negatif kontrol serumları ise sağlıklı beș adet köpekten elde edilmiștir.

Mikro Standart Tüp Aglutinasyon Testi (mSAT), Regnault (9)'un bildirdiği yöntemin mikropleytlere uyarlanması ile gerçekleștirilmiștir. L. monocytogenes tüp aglutinasyon antijeni, Refik Saydam Hıfzıssıhha Merkezi Bașkanlığı'ndan temin edilmiștir. Serum örneklerinin, $1 / 4$ ile $1 / 2560$ arasında çift katlı seri dilüsyonları fizyolojik tuzlu su ile yapılmıștır. Daha sonra tüm çukurlara $50 \mu \mathrm{l}$ tüp aglütinasyon antijeni dağıtılarak $37{ }^{\circ} \mathrm{C}$ 'de 24 saat inkübe edilmiştir. Süre sonunda $1 / 160$ ve üstü dilüsyonlarda tam aglütinasyonun görülmesi pozitif olarak değerlendirilmiștir.

Enzyme Linked Immunosorbent Assay (ELISA) testinde kullanılan somatik $O$ antijeni, Peel ve ark. (10)'nın bildirdiği yönteme göre hazırlanmıștır. Refik Saydam Hıfzıssıhha Merkezi Bașkanlığı'ndan temin edilen L. monocytogenes antijeni, 4.000 rpm'de 10 dakika santrifüj edilmiș ve fosfat tampon çözeltisi (PBS) ile üç kez yıkanmıştır. Pelet az miktarda PBS ile sulandırılmış ve beș dakika sonikatörde tutularak bakteriler parçalanmıștır. Antijenin protein konsantrasyonu, Lowry ve ark. (11)'nin önerdiği yönteme dayanan DC protein assay (Cat No. 500-0116, Bio-Rad Lab. USA) ile belirlenmiștir.

ELISA testi, Low ve Donachie (12)'nin bildirdiği yönteme göre standardize edilerek uygulanmıștır. Optimum antijen ve Anti-Dog lgG HRP konjugat (Sigma, A-9042) konsantrasyonları ile serum dilüsyonunu belirlemek için dama tahtası yöntemi kullanılmıștır. Optimum antijen, konjugat ve serum dilüsyonları sırasıyla $100 \mu \mathrm{g} / \mathrm{ml}, 1 / 2000$ ve $1 / 100$ olarak belirlenmiștir. Immulon II mikropleytlere (Nunc C bottom Immunplate 96 well, 446612) $0.05 \mathrm{M}$ karbonat-bikarbonat tampon'da ( $\mathrm{pH}$ 9.6) homojenize edilen $100 \mu \mathrm{l}$ antijen aktarılarak $37^{\circ} \mathrm{C}$ 'de bir gece tutulmuştur. Bu süre sonunda mikropleytler yıkama solüsyonu (\%0.05 Tween 80 içeren PBS, pH 8) ile beș kez yıkanmıștır. Daha sonra antijen yapışmayan polysytren yüzeylerin nötralizasyonu (Blocking step) amaciyla $200 \mu \mathrm{l}$, \%1'lik sığır serum albümini (BSA, Sigma A8531) postcoat solüsyonu șeklinde hazırlanarak her bir göze eklenmiș, $37^{\circ} \mathrm{C}$ 'de 1,5 saat bekletildikten sonra beș kez yıkanmıștır. Sulandırma solüsyonu (\%1 BSA ve \%0,05 Tween 20 içeren PBS) ile 1/100 oranında sulandırılmış kontrol ve test serumlarından $100 \mu \mathrm{l}$ alınarak mikropleytin ilgili gözlerine ilave edilerek $37{ }^{\circ} \mathrm{C}$ 'de bir saat inkübe edilmiștir. Pleytler beș kez yıkandıktan sonra sulandırma solüsyonu ile 1/2.000 oranında sulandırılmıș konjugattan tüm gözlere $100 \mu \mathrm{l}$ ilave edilip $37^{\circ} \mathrm{C}$ ' de bir saat tutulmuștur. Yıkama ișleminden sonra tüm gözlere $100 \mu \mathrm{l} T M B$ substrate (Sigma, SIT-0440) ilave edilerek oda Isısında 5-10 dakika inkübe edilmiștir. Stop solüsyonundan $\left(2 \mathrm{M} \mathrm{H}_{2} \mathrm{SO}_{4}\right) 100 \mu$ eklenerek ELISA reader'da (MWGt Lambda Scan 200 Bio-Tek Inst. Inc. USA.) 450 nm dalga boyunda mikropleytlerin absorbans değerleri okutulmuștur. Cut-off değerine (1.216) eșit veya yüksek absorbans değerine sahip örnekler pozitif olarak kabul edilmiștir.

İstatistik analizler Minitap-SPSS paket programı kullanılarak Mc Nemar Testi ve Fisherin Kesin X2 Testi ile yapılmıștır. İstatistiki olarak önemlilik $p<0,05$ değeri ile ifade edilmiștir.

\section{BULGULAR}

Toplam 135 kan serum örneğinden 31 (\%23)' $i$ mSAT ile aglütinasyon vermiş ve listeriozis yönünden pozitif olarak kabul edilmiștir. Yüz dört adet (\%77) örnek listeriozis negatif olarak saptanmıștır. Pozitif kan serumlarına ait aglütinasyon titreleri Tablo 1'de 
Tablo 1. Serumların mSAT ve ELISA ile analiz sonuçları

\begin{tabular}{|c|c|c|c|c|c|c|c|c|}
\hline \multirow{2}{*}{ Kaynak } & \multicolumn{6}{|c|}{ mSAT titreleri } & \multicolumn{2}{|c|}{ ELISA } \\
\hline & $\leq 1 / 80^{*}$ & $1 / 160$ & $1 / 320$ & $1 / 640$ & $1 / 1280$ & $1 / 2560$ & Pozitif & Negatif \\
\hline Belediye Barınağı & 80 & 14 & 6 & 5 & - & 1 & 21 & 85 \\
\hline $\begin{array}{l}\text { S.Ü.Veteriner Fakültesi } \\
\text { Uygulama Çiftliği }\end{array}$ & 16 & 2 & 2 & - & - & - & - & 20 \\
\hline $\begin{array}{l}\text { S.Ü. Veteriner Fakültesi } \\
\text { Klinikleri }\end{array}$ & 8 & - & 1 & - & - & - & - & 9 \\
\hline Toplam & 104 & 16 & 9 & 5 & - & 1 & 21 & 114 \\
\hline
\end{tabular}

* mSAT ile negatif kabul edildi.

verilmiștir. Örneklerin 21 (\%15,5)'i ELISA testi ile pozitif, $114(\% 84,5)$ 'ü ise negatif olarak belirlenmiștir. Bu çalıșmada kullanılan iki ayrı serolojik test ile elde edilen sonuçlar arasındaki farkların istatistiksel olarak önemli $(p<0,05)$ olduğu tespit edilmiștir (Tablo 2).

Örneklerin elde edildiği kaynak bazında yapılan incelemede ise kan örneklerinin toplandığı belediye köpek barınağı, üniversite çiftliği köpek ünitesi ve SÜVF kliniklerine getirilen köpeklere ait pozitiflik, mSAT ile sirasıyla $\% 24,5, \% 20$ ve $\% 11,1$ ve ELISA ile sırasıyla $\% 19,8 \% 0$ ve $\% 0$ olarak saptanmıștır. ELISA test sonuçlarına göre, belediye köpek barınağı ile diğer iki kaynağa ait köpeklerdeki sero-pozitiflik farklıığı istatistiksel olarak önemli $(p<0,05)$ bulunmuștur.

Tablo 2. ELISA ve mSAT test sonuçlarının karșılaştırılması

\begin{tabular}{lcccc}
\hline \multirow{2}{*}{ Testler } & & \multicolumn{2}{c}{ mSAT } & Toplam \\
\cline { 3 - 4 } & & Pozitif & Negatif & \\
\hline \multirow{2}{*}{ ELISA } & Pozitif & 17 & 4 & 21 \\
& Negatif & 14 & 100 & 114 \\
\hline & Toplam & 31 & 104 & 135 \\
\hline
\end{tabular}

\section{TARTIŞMA}

Zoonoz enfeksiyonlardan olan listeriozis, insanlarda ve hayvanlarda abortus, septisemi ve meningoensefalitise neden olmaktadır (1). İnsanlarda görülen listeriozis vakalarının son yıllarda artması enfeksiyonun halk sağlığı yönünden önemini göstermektedir (13). Doğada bulunan L. monocytogenes suşlarının önemli kaynaklarından birisinin dıșkıları ile çevreyi kontamine eden portör hayvanlar olduğu bildirilmiştir (2). Köpeklerin L. monocytogenes fekal taşıyıcılığı çeșitli ülkelerde araștırılmıș ve \%0,9-1,3 oranlarda tașıyıcılık tespit edilmiștir $(14,15)$. Ülkemizde yapılan bir çalıșmada da, Bursa ilinde sokak köpeklerinin L. monocytogenes fekal taşıyıcılığı \%1,22 olarak tespit edilmiștir (16).

$\mathrm{Bu}$ çalıșmada, Konya il merkezinde bulunan belediye köpek barınağı ve SÜVF Köpekçilik Araștırma ve Uygulama Ünitesinde bulunan köpekler ile SÜVF Kliniklerine aşılama için getirilen köpeklerde L. monocytogenes varlığının serolojik olarak araștırılması amaçlanmıștır. Bu kapsamda incelenen toplam 135 adet serumun 31'i mSAT ile pozitif bulunurken, aynı serumların sadece $21^{\prime} i$ ELISA ile pozitif bulunmuștur. Bu iki test ile elde edilen sonuçlar arasındaki fark çapraz reaksiyondan meydana gelmiș olabileceği düșünülmektedir. 
Tüm hücre antijeninin kullanıldığı aglütinasyon testlerinde, L. monocytogenes ile bazı Gram-negatif ve Gram-pozitif bakteriler (Staphylococcus aureus, Streptococcus faecalis, Corynebacterium pyogenes, Bacillus subtillis ve Escherichia coli K8) arasında çapraz reaksiyonun olabileceği bildirilmiștir (17). Bourry ve ark. (18) L.monocytogenes antikorlarının varlığını ELISA yöntemi ile değerlendirdiklerinde testin özgüllük ve duyarlılığını \%88 ve \%100 olarak bulmușlardır. Bu çalıșmada da, listeriozisin serolojik tanısında, ELISA testinin aglütinasyon testi olan mSAT'a göre antikorları belirlemede daha spesifik olduğu sonucuna varılmıștır.

Ülkemizde listeriozisin köpeklerdeki varlığını serolojik olarak belirleyen sınırlı sayıda çalıșma bulunmaktadır. Ceylan ve ark. (4), Van yöresindeki 90 sokak köpeğini serum aglütinasyon testi ile incelemișler ve \%40 oranında seropozitiflik belirlemișlerdir. Babür ve ark. (6) Şanlıurfa İli sokak köpeklerinde yaptıkları çalıșmada listeriozis seroprevalansını \%18,75, Aktaș ve ark. (7) ise Erzurum yöresi sokak köpeklerinde bu oranı \%26,3 olarak rapor etmișlerdir. Gıcık ve ark. (8) Kars ilinin değişik odaklarında ki sahipli köpeklerde listeriozisin serolojik varlığını \%22,3 olarak bildirmișlerdir. Bizim çalıșmamızda, ELISA testi ile elde ettiğimiz \%21'lik seropozitiflik oranı, Babür ve ark. (6), Aktaș ve ark. (7) ve Gıcık ve ark. (8)'nın sonuçları ile uyumlu fakat Ceylan ve ark. (4) belirlediği \%40’lık orandan düșük bulunmuștur. Bu farklılık, kullanılan testlerin özgüllüğünün farklı olmasından kaynaklanmış olabileceği gibi bölgesel farklılıktan da ileri gelmiș olabilir.

Kan serum örneklerinin elde edildiği köpeklerin ait olduğu kaynaklar incelendiğinde, ELISA test sonuçlarına göre sadece belediye köpek barınağında yaşayan sokak köpeklerinin \%19,8'i listeriozis yönünden pozitif olarak saptanmıștır. Buna karșın, SÜVF Köpekçilik Araștırma ve Uygulama Ünitesinde bulunan köpekler ile SÜVF kliniklerine getirilen köpeklerde enfeksiyonun seroprevalansı sıfır olarak bulunmuștur. L. monocytogenes suşlarının çevreye yayılmasında ve insanlara bulaşmasında önemli kaynaklarından birisinin, dışkıları ile çevreyi kontamine eden portör hayvanlar olduğu bildirilmiștir (2). Bu durum göstermektedir ki, sokak köpekleri yüksek seropozitiflik oranları ile halk sağlığı açısından riskli bir popülasyondur.

Konya bölgesi sokak köpeklerinde yüksek sayılabilecek bir oranda L. monocytogenes seropozitifliği tespit edilmiștir. Konya Bölgesinde risk grubu insanlarda enfeksiyonun prevalansının tespit edilmesi, köpek kaynaklı bulașma olasılığının araștırılması gerektiği sonucuna varılmıștır.

\section{KAYNAKLAR}

1. Low JC, Donachie W. A review of Listeria monocytogenes and listeriosis. Vet J, 1997; 153: 9-29.

2. Skovgaard N, Norrung B. The incidence of Listeria spp. in faeces of danish pigs and in minced pork meat. Inter J Food Microbiol, 1989; 8: 59-63.

3. Gasanov U, Hughes D, Hansbro PM. Methods for the isolation and identification of Listeria spp. and Listeria monocytogenes: A review. FEMS Microbiol Rev, 2005; 29: 851-75.
4. Ceylan E, Karaca K, Akkan HA, Keles I, Kutlu I. Van yöresi sokak köpeklerinde listeriozis seroprevalansı. YYU Saglık Bil Derg, 2005; 8(1-2): 15-17.

5. Fung DYC. Rapid methods and automation in microbiology. Compr Rev Food Sci F, 2002; 1: 3-21.

6. Babür C, Altaș MG, Çelebi B, Sevgili M, Özkan AT, Gökçen A. Şanlıurfa yöresi sokak köpeklerinde toxoplasmosis, leishmaniosis ve listeriosis'in seroprevalansı. Türk Hij Den Biyol Derg, 2007; 64: 11-16. 
7. Aktaș MS, Özkanlar YE, Özkan AT, Babür C, Balkaya i. Erzurum İli barınak köpeklerinde listeriosis ve leishmaniasisin seroprevalansının araștırılması. Türkiye Parazitol Derg, 2010; 34(2): 76-80.

8. Gıcık Y, Sarı B, Babür C, Çelebi B. Kars yöresinde köpeklerde Toxoplasma gondii ve Listeria monocytogenes'in seropozitifliği. Türkiye Parazitol Derg, 2010; 34 (2): 86-90.

9. Regnault JP. Immunologie Generale. Lausanne: Vigot Pub, 1988.

10. Peel M, Donachie W, Shaw A. Temperaturedependent expression of flagella of Listeria monocytogenes studied by electon microscopy, SDS-PAGE and western blotting. J Gen Microbiol, 1988; 1: 2171-8.

11. Lowry $\mathrm{OH}$, Rosembrogh $\mathrm{NJ}$, Farr $\mathrm{AL}$, Randall RJ. Protein measurement with the folin phenol reagent. J Biol Chem, 1951; 193: 265-75.

12. Low JC, Donachie W. Clinical and serum antibody responses of lambs to infection by Listeria monocytogenes. Res Vet Sci, 1991; 51: 185-92.
13. Ramaswamy V, Cresence VM, Rejitha JS, Lekshmi MU, Dharsana KS, Prasad SP, et al. Listeria- Review of epidemiology and pathogenesis. J Microbiol Immunol Infect, 2007; 40: 4-13.

14. Weber A, Potel J, Schafer-Schmidt R, Prell A, Datzmann C. Studies on the occurrence of Listeria monocytogenes in fecal samples of domestic and companion animals. Zentralbl Hyg Umweltmed, 1995; 198: 117-23.

15. Iida T, Kanzaki M, Nakama A, Kokubo Y, Maruyama T, Kaneuchi C. Detection of Listeria monocytogenes in humans, animals and foods. J Vet Med Sci, 1998; 60: $1341-3$.

16. Kocabıyık AL, Cetin C, Özakın C. Faecal carriage of Listeria monocytogenes in stray dogs in Bursa province, Turkey. Turk J Vet Anim Sci, 2005; 29: 1357-1359.

17. Bhunia AK. Antibodies to Listeria monocytogenes. Crit Rev Microbiol, 1997; 23: 77-107.

18. Bourry A, Cochard T, Poutrel B. Serological diagnosis of bovine, caprine, and ovine mastitis caused by Listeria monocytogenes by using an enzyme-linked Immunosorbent assay. J Clin Microbiol, 1997; 35(6): 1606. 


\title{
S19 hayvan așısının kazayla inokülasyonu sonucu gelișmiş bir bruselloz olgusu
}

\section{A case of human brucellosis associated with unintentional inoculation of the animal vaccine S19}

\author{
Ahmet KARAKAȘ¹， Gürkan MERT ${ }^{1}$ ， Ömer COŞKUN¹, \\ Ömer Hilmi ALGA²， Bülent Ahmet BEŞiRBELLioĞLU1， Can Polat EYiGüN'
}

\section{ÖZET}

Bruselloz, gram negatif kokobasil olan Brucella cinsi bakterilerin neden olduğu, insanlarda ateș, terleme, kas ve eklem ağrısı gibi belirtilerle seyreden bir zoonotik hastalıktır. Bruselloz esas olarak enfekte hayvanlarla temas ve enfekte süt-süt ürünlerinin tüketilmesi ile bulașmasına rağmen, literatürde așı kaynaklı olgular da nadiren bildirilmektedir. Burada; genç sığırların așılanması sırasında canlı Brucella abortus S19 așısına maruz kalan bir veteriner hekimde gelișen mesleki bruselloz olgusu sunulmuștur. Yirmi dört yașındaki erkek veteriner hekim, B. abortus S19 așısı ile sığırları așılarken aşıyı yanlıșlıkla sol el bașparmağına inoküle etmiștir. Hasta, așı inokülasyonundan 36 saat sonra Kocaeli Özel Konak Hastanesine bașvurmuştur. Illk müracaat ettiğinde așı inokülasyon yerinde ödem, șișlik ve hassasiyet saptanmış, diğer fizik muayene bulguları normal olarak değerlendirilmiștir. Bașlangıçta çalıșılan serolojik testler (Rose Bengal ve serum tüp aglütinasyon testi) negatif, rutin biyokimyasal testler ise normal sınırlarda bulunmuștur. Ayrıca inokülasyon yerinden alınan yara kültüründe bakteri izole edilememiștir. Hasta, doksisiklin ile kemoproflaksi uygulanmasına rağmen olaydan 21 gün sonra ateș, terleme ve testis ağrısı ile tekrar bașvurduğu ikinci müracaatında ateși $38,3{ }^{\circ} \mathrm{C}$ olarak saptanmış, inokülasyon bölgesinde fleksiyon sırasında ağrı ve gerginlik yakınması olduğu belirlenmiștir. Laboratuvar incelemesinde aspartat aminotransferaz (AST) $32 \mathrm{U} / \mathrm{L}$, alanin aminotransferaz (ALT) $25 \mathrm{U} / \mathrm{L}$, CRP $8,94 \mathrm{mg} / \mathrm{dL}$, serolojik incelemede

\section{ABSTRACT}

Brucellosis is a zoonotic disease caused by Brucella species that is a gram negative coccobacilli and can cause symptoms such as fever, diaphoresis, arthalgia and myalgia. Although humans become infected by contact with animals or consuming dairy products that are contaminated with Brucella, cases in which humans are infected by vaccination are rarely mentioned in the literature. Here, we present the a case of a 24-year old veterinarian who was diagnosed with brucellosis upon being exposed to Brucella abortus S19 while vaccinating a young cattle and accidentally inoculating the pathogen to the thumb of his left hand. He was admitted to the Kocaeli Özel Konak hospital 36 hours after the inoculation with an edema and sensitivity to pressure in the innoculation site, while the other physical examination findings were normal. At this stage theserological tests (Rose Bengal and agglutination) were negative, while the routin biochemical tests were within normal range. In addition, samples collected from the inoculation site didn't show any bacterial growth. Despite chemoprophylactic treatment with doxycycline, the patient developed fever, diaphoresis, and testicular pain 21 days after the contact. His body temperature was $38.3^{\circ} \mathrm{C}$ and the patient complained about pain when the finger was bended during his second visit. Laboratory tests showed the aspartat aminotransferaz (AST) level was $32 \mathrm{U} / \mathrm{L}$, alanin aminotransferaz (ALT) $25 \mathrm{U} / \mathrm{L}$, and CRP $8.94 \mathrm{mg} / \mathrm{dL}$. The

Gülhane Askeri Tıp Fakültesi, Enfeksiyon Hastalıkları ve Klinik Mikrobiyoloji Ana Bilim Dalı, ANKARA

2 Özel Konak Hastanesi, KOCAELi

İletişim/ Corresponding Author : Ahmet KARAKAŞ Gülhane Askeri Tıp Fakültesi, Enfeksiyon Hastalıkları ve Klinik Mikrobiyoloji Ana Bilim Dalı, ANKARA Geliş Tarihi / Received : $24,10,2011$ Tel : +903123044308 E-posta/E-mail : akarakas@gata.edu.tr Kabul Tarihi/Accepted : 05.02 .2012 
Rose Bengal pozitif ve standart tüp aglütinasyon testi $1 / 320$ olarak saptanmıștır. Alınan kan kültüründe bakteri izole edilmemiștir. Hastaya klinik belirti ve serolojik bulgular ışığında bruselloz tanısı konarak altı hafta süreyle doksisiklin (200 $\mathrm{mg} /$ gün $)$ ve rifampisin (600 mg/gün) kombinasyon tedavisi verilmiștir. Takip muayenelerinde semptomları kaybolmuș ve relaps görülmemiștir. Veteriner hekimler așı kaynaklı bruselloz açısından risk altındadırlar. Așıya maruz kalanlara proflaksi uygulanmalıdır. Ancak aşıya maruziyet sonrasinda uygulanacak proflaksinin her zaman hastalık gelișimini engelleyemeyeceği ve temaslıların yakından takip edilmesi gerektiği unutulmamalıdır.

Anahtar Sözcükler: Bruselloz, Brusella așıları, Mesleki temas, Veteriner; S19 așısı

\section{Giriș}

Bruselloz gram negatif kokobasil olan Brucella cinsi bakterilerin neden olduğu, insanlarda ateș, terleme, kas-eklem ağrısı gibi belirtilerle seyreden bir zoonotik hastalıktır. Hastalık esas olarak hayvanlarla direkt temas, enfekte et ve süt ürünlerinin tüketilmesi ile bulașır (1). Bununla birlikte; inhalasyon, solid organ ve hematopoetik kök hücre nakli, cinsel ilișki ve veteriner hekimlikte kullanılan brusella aşılarına maruziyet sonucu da hastalık geliștiği bildirilmiștir $(2-4)$.

Bu makalede bir veteriner hekimde canlı Brucella abortus S19 așısına maruziyet sonucu gelișen bir bruselloz olgusu sunulmuş ve literatür ıșığında temas sonrası olgu yönetimi gözden geçirilmiștir.

\section{OLGU}

B. abortus S19 așısı ile sığırları așılarken așıyı yanlıșlıkla sol el bașparmağına inoküle eden 24 yaşındaki erkek veteriner hekim olaydan 36 saat sonra inokülasyon yerinde ağrı, kızarıklık ve șișlik şikâyeti ile Kocaeli Özel Konak Hastanesi polikliniğine bașvurmuștur. Özgeçmișinde bir özellik olmayan ve daha önce bruselloz geçirmediğini ifade eden hastanın bașvurusu sırasında ateși $36{ }^{\circ} \mathrm{C}$, arteryel serological tests conducted later showed that the Rose Bengal and the standard serum agglutination test were positive at $1 / 320$, while the blood culture was negative. Based on clinical and serological findings, the patient was diagnosed with brucellosis and treated successfully a combination of doxycycline (200 mg/day) and rifampicin (600 mg/day) for six weeks. The following examinations didn't show any symptoms and no relapse was noted. Veterinarians are at risk to be infected with Brucella during vaccination, therefore those infected should receive prophylactic treatment. However, post exposure prophylactic treatment won't always prevent progress of the disease and patients need to be followed up closely.

Key Words: Brucellosis, Brucella Vaccines, Occupational Exposure, Veterinerian; S19 Vaccine

kan basıncı 110/70 mmHg, nabzı 80 atım/dk olarak saptanmıștır.

Fizik muayenesinde sol el başparmak distal eklem üzerinde ödem, hiperemi ve hassasiyet tespit edilmiștir. Diğer fizik muayene bulguları normal olarak değerlendirilmiștir. Laboratuvar incelemesinde; C-reaktif protein (CRP) $27 \mathrm{mg} / \mathrm{dL}$, Rose Bengal ve serum tüp aglütinasyon (STA) testi negatif bulunmuş, rutin biyokimyasal testler ve tam kan sayımı normal olarak saptanmıștır.

Yara kültürünün Brucella agara yapılan ekimlerinde bakteri izole edilememiștir. Hastaya 21 gün süreyle $2 \times 100 \mathrm{mg} /$ gün doksisiklin proflaksisi planlanmasına karșın, hasta temastan 20 gün sonra ateș, terleme ve testislerinde ağrı şikâyeti ile tekrar bașvurmuștur. İkinci ziyaretinde ateș $38,3{ }^{\circ} \mathrm{C}$, arteryel kan basıncı 110/70 mmHg, nabız 90 atım/ $\mathrm{dk}$, inokülasyon bölgesinde bașparmağın fleksiyonu ile ortaya çıkan ağrı ve gerginlik belirlenmiștir. Laboratuvar incelemesinde aspartat aminotransferaz (AST) $32 \mathrm{U} / \mathrm{L}$, alanin aminotransferaz (ALT) $25 \mathrm{U} / \mathrm{L}$, CRP 8,90 mg/dL, serolojik incelemede Rose Bengal pozitif ve STA $1 / 320$ olarak saptanmıștır. Alınan kan kültüründe bakteri izole edilmemiștir. Hastaya 
klinik belirti ve serolojik bulgular ışığında bruselloz tanısı ile altı hafta süreyle doksisiklin 2×100 mg/gün ve rifampisin $1 \times 600 \mathrm{mg} /$ gün kombinasyon tedavisi verilmiş, takip muayenelerinde semptomlarının kaybolduğu ve relaps görülmediği belirlenmiștir.

\section{TARTIŞMA}

Bruselloz esas olarak insanlara enfekte hayvanlarla temas, kontamine et ve süt ile süt ürünlerinin tüketilmesiyle bulașmakla birlikte nadir de olsa, cinsel ilișki, kemik iliği nakli ve canlı brusella așılarıyla temas sonucu gelișen olgular da rapor edilmektedir (1, 3-6).

Insanlarda brusellozun kontrol altına alınabilmesi ancak hastalığın evcil hayvanlarda eradikasyonu ile mümkündür. Bu maksatla geliștirilen brusella așıları (S19, RB51 ve Rev-1 vb.) dünyanın değişik ülkelerinde kullanılmaktadır (7). Ülkemizde 1960 yılında Brucella abortus içeren S19 aşısı (büyükbaș hayvanlar için) ve 1969 yılında B. melitensis içeren Rev-1 aşısı (küçükbaș hayvanlar için) üretilmeye başlanmıștır (8). Tarım Orman ve Köy İşleri Bakanlığı tarafından hayvan brusellozunun kontrolü amaciyla 1986 yılında “Türkiye Brusellozis Mücadele Projesi” bașlatılmıș ve 26 yıl sürdürülmesi hedeflenmiștir (9). Proje kapsamında brusella aşısının yoğun olarak kullanıldığı ülkemizde, veteriner hekim ve teknisyenler arasında aşıya maruziyet sonucu gelișen bruselloz olgularının olması beklenir. Ancak etkin bir sürveyans sisteminin bulunmaması nedeniyle, aşıya kaza sonucu maruz kalan ve enfeksiyon gelișen olgu sayısı tam olarak bilinmemektedir.

Literatürde aşının yanlışılıkla inokülasyonuna bağlı olarak gelișmiş sınırlı sayıda bruselloz olgusu bulunmaktadır. Ashford ve arkadașlarının yaptıkları çalıșmada; RB51 B. abortus așısına yanlıșlıkla maruz kalan 26 kişinin büyük çoğunluğunun veteriner hekim (21 kişi) olduğu bildirilmiştir. Maruziyet șekli incelendiğinde; 21'inde iğne batması, dördünde aşısının konjunktivaya sıçraması, birinde ise aşının ciltteki açık yarayla teması sonucu meydana geldiği belirtilmiștir. Antibiyotik proflaksisi (doksisiklin veya doksisiklin + gentamisin/amoksisilin/siproflaksisin) uygulanan 25 temaslının 19 (\%76)'unda en az bir sistemik belirti (ateș, üșüme, terleme, halsizlik, ishal, kas-eklem ağrısı gibi) geliștiği, \%27'sinde de bu belirtilerin altı aydan uzun sürdüğü saptanmıștır (4). Bunun dışında, aşı sonrası (RB51 aşısı) düşük yapan bir sığır fetüsü ile temas eden sekiz kişiye proflaksi uygulandığı (beș kișiye doksisiklin, üç kișiye doksisiklin + rifampisin) ve hiçbirinde bruselloz gelișmediği bildirilmiștir (5). Blasco ve arkadașları, Rev-1 aşısına kazayla maruz kalan ve proflaksi uygulanmayan iki veteriner hekimde akut bruselloz tablosu geliștiğini bildirmişlerdir (10). Bunlara ilave olarak, Güney Afrika'da Brusella aşısı flakonu ile oynayan bir çocukta akut enfeksiyon tablosu geliștiği ifade edilmiștir (7). Benzer şekilde, Arjantin'de B. abortus S19 așısının üretildiği bir fabrikada çalıșan 30 ișçinin \%70 (21 kişi)'inde bruselloz geliștiği ve bunlardan sadece dokuzunun kaza sonucu teması (perkütan, inhalasyon ve konjunktival yolla) hatırlayabildiği belirtilmiștir (11).

Temas sonrasında bruselloz gelișimini önlemek amacıyla 3-6 haftalık proflaksi süresi yeterli olabilmektedir (12-14). Dünya Sağlık Örgütü'nce proflaksi süresi altı hafta olarak belirlenmiștir. Așının cilde inokülasyonu durumunda lokal yara bakımı, tetanoz proflaksisi ve doksisiklin verilmesi, aşının konjunktivaya sıçraması durumunda ise lokal temizlik ve tek veya ikili kombinasyon ile (doksisiklin + rifampisin veya trimetoprim-sülfametoksazol) proflaksi önerilmektedir. RB51 aşısı için kullanılan sușun rifampisine dirençli olması nedeniyle proflaksi ve tedavide kullanılmaması gerektiği belirtilmektedir (13). Amerika Hastalık Kontrol ve Önleme Merkezi (CDC)'nce laboratuvar kaynaklı temaslarda proflaksi süresi üç hafta olarak belirlenmiștir. Yüksek riskli temas (laboratuvarda Brucella kültürlerinin koklanması, perkütan temas ve bakterinin konjunktiva, ağız ve buruna inokülasyonu veya sıçraması) durumunda doksisiklin $(2 \times 100 \mathrm{mg} /$ gün$)$ ve rifampisin (1×600 $\mathrm{mg} /$ gün) kombinasyonu, doksisiklin kullanımının kontrendike olduğu durumlarda doksisiklin yerine trimetoprim-sülfametokzasol $(160 \mathrm{mg} / 800 \quad \mathrm{mg})$ kullanılabileceği belirtilmektedir. Ayrıca temaslıların 
serum örneklerinin alınarak bașlangıç serolojik durumlarının belirlenmesi, altı ay boyunca haftalık periyotlarla akut hastalık gelișimi açısından (ateș ve brusellozun diğer klinik belirtileri) izlenmesi ve 2., 4., 6., 24. haftalarda serum aglütinasyon testlerinin tekrarı önerilmektedir (14).

Burada sunulan ve sığır așılaması sırasında yanlıșlıkla aşıyı kendine inoküle eden olguda inokülasyon yerinde meydana gelen lokal reaksiyonlar (șișlik, kızarıklık, ağrı) üç hafta içerisinde kaybolmuștur. Ancak așının inokülasyonundan sonra doksisiklin proflaksisine rağmen akut bruselloz tablosu gelișmiștir. Bu nedenle olgu daha sonra altı hafta süreyle doksisiklin ve rifampisin kombinasyonu ile tedavi edilmiștir. Her ne kadar kan ve yara kültürlerinde bakteri izole edilememiș olsa da, olgunun daha önce bruselloz geçirmemiș olması, inokülasyondan hemen sonra negatif bulunan ve üçüncü haftada tekrarlanan serolojik testlerde serokonversiyon (Rose Bengal: pozitif, STA:1/320)

\section{KAYNAKLAR}

1. Young EJ. Brucella species. In: Mandell GL, Bennet JE, Dolin R (eds). Mandell, Douglas, and Bennett's Principles and Practice of Infectious Diseases, 6th ed. Philadelphia, Churchill Livingstone, 2005; 2669-74.

2. Kotton C.N., Zoonoses in solid-organ and hematopoietic stem cell transplant recipients. Clin Infect Dis, 2007; 44 (6): 857-66.

3. Meltzer E, Sidi Y, Smolen G, Banai M, Bardenstein S, Schwartz E. Sexually transmitted brucellosis in humans. Clin Infect Dis, 2010; 51 (2): 12-5.

4. Ashford DA, di Pietra J, Lingappa J, Woods C, Noll $\mathrm{H}$, Neville B. et al., Adverse events in humans associated with accidental exposure to the livestock brucellosis vaccine RB51. Vaccine, 2004; 22 (25-26): 3435-9.

5. Bardenstein S, Mandelboim M, Ficht TA, Baum M, Banai M. Identification of the Brucella melitensis vaccine strain Rev. 1 in animals and humans in Israel by PCR analysis of the Pstl site polymorphism of its omp2 gene. J Clin Microbiol, 2002; 40 (4): 1475-80.

6. Centers for Disease Control and Prevention. Human exposure to Brucella abortus strain RB51-Kansas, 1997. MMWR Morb Mortal Wkly Rep, 1998; 47 (9): 172-5. saptanması hastalığın așı sușundan kaynaklandığını doğrulamaktadır.

Sonuç olarak; ülkemizde bruselloz, hayvan așılama faaliyetlerine rağmen halen yaygın olarak görülmektedir. Kitlesel hayvan aşılamaları sırasında istenmeyen maruziyetlerin olabileceği unutulmamalıdır. Maruziyet durumunda lokal yara bakımından (yara temizliği ve gerekirse tetanoz proflaksisi) sonra uygun antibiyotik proflaksisi uygulanmalı ancak antibiyotik proflaksisinin her zaman hastalık gelișimini engelleyemeyeceği göz önünde bulundurulmalı ve temaslılar yakından takip edilmelidir. Ülkemizde așıya bağlı insan bruselloz olgu sayısı tam olarak bilinmemektedir. Bu konuda yapılacak aktif sürveyans; istenmeyen maruziyet sayısının doğru olarak saptanması, maruziyet sonrası uygulanan proflaktik yaklașımın etkinliğinin belirlenmesi ve hastalık geliștiğinde uygun șekilde tedavi edilmesi açısından önemli olacaktır.

7. Berkelman RL. Human illness associated with use of veterinary vaccines. Clin Infect Dis, 2003; 37 (3): 407-14.

8. http://penvet.gov.tr/lab.asp?a=b\&id=33 (Erișim Tarihi: 16.12.2011).

9. http://www.kkgm.gov.tr/birim/hay_sagl/ Hastaliklar/brucella.htm (Erișim Tarihi: 16.12.2011).

10. Blasco JM, Diaz R. Brucella melitensis Rev-1 vaccine as a cause of human brucellosis. Lancet, 1993; 342 (8874): 805.

11. Wallach JC, Ferrero MC, Victoria Delpino $M$, Fossati CA, Baldi PC. Occupational infection due to Brucella abortus S19 among workers involved in vaccine production in Argentina. Clin Microbiol Infect, 2008; 14 (8): 805-7.

12. Kılıç S, Babür C. Biyolojik silah olarak bakteriler: Kategori B ajanlar. Türk Hij Den Biyol Derg, 2006; $63(1,2,3)$ : 47-66.

13. http://www.who.int/csr/resources/publications/ Brucellosis.pdf (Erișim Tarihi: 16.12.2011).

14. Laboratory-acquired brucellosis-Indiana and Minnesota, 2006. MMWR Morb Mortal Wkly Rep, 2008; 57 (2): 39-42. 


\title{
Gıdalarda aflatoksin varlığının değerlendirilmesi
}

\author{
The evaluation of the aflatoxin presence in foods
}

\author{
Gülderen YENTÜR ${ }^{1}, \quad$ Buket ER ${ }^{1}$
}

\section{ÖZET}

Aflatoksinler tahıllar, yağı tohumlar, baharatlar, etler, süt ve süt ürünlerini içeren pek çok gıda ile hayvan yemlerinde yaygın olarak bulunabilen mikotoksinlerdir. Gıdalar ve hayvan yemleri ürün ișleme, depolama ve satıș sırasında aflatoksinlerle kontamine olabilmektedir. Aflatoksin kontaminasyon düzeyleri iklimsel, bölgesel özellikler veya gıda çeșidine göre farklılıklar gösterebilmektedir. Aflatoksinler genellikle gidalarda ve yemlerde stabil ve sıcaklığa karșı dirençlidirler. Bu toksinlerin olușumu için gereken koșullar devam ettiğinde kontaminasyon oranı artabilmektedir. Kontamine olan gıdaların aflatoksinlerden tamamen arındırılması da pek mümkün görünmemektedir. Aflatoksin detoksifikasyonu yeterli olmadığı için kontaminasyonun kontrol altında tutulması gerekmektedir. Aflatoksin oluşumunun önlenmesi için üretimden tüketime kadar çeșitli șekillerde bulașan küflerin gelișiminin ileri teknolojiler ve iyi uygulamalarla engellenmesi gerekmektedir. Aflatoksinler insanlara kontamine gidalar ve kontamine yemlerle beslenen hayvanlardan elde edilen ürünler aracılığıyla ulașarak akut veya kronik toksisiteye neden olabilmektedir. Toksisite derecesini maruziyet düzeyi, yaș, cinsiyet, beslenme ve bazı sağlık faktörleri etkilemektedir. Aflatoksinler en toksik mikotoksinlerdir. Yapılan çalıșmalarda aflatoksinlerin toksik, kanserojenik, teratojenenik,

\section{ABSTRACT}

Aflatoxins are mycotoxins that are widely found in food products such as cereals, oil seeds, spices, meat, milk and milk products and also animal feeds. Food for humans and animals could be contaminated with aflatoxins during the product processing, storage and sale. Levels of aflatoxin contamination also may vary according to the climate, regional characteristics or type of food. Aflatoxins in food and feed are usually stable and resistant to heat. The contamination rate may increase when the conditions for the formation of these toxins continue existing. Apparently, it is not possible to completely purify contaminated food from aflatoxins or detoxify the aflatoxin. To prevent accumulation of aflatoxin, contamination of the food with molds should be prevented with developing technologies and best practices. Humans come in contact with aflatoxin through contaminated food and animal products. As a result, aflatoxin can cause acute or chronic toxicitiy, while the quantity of aflatoxin injested, the age, sex, and health factors might affect the degree of toxicity. Aflatoxins are one of the most toxic mycotoxins. In previous studies it was shown that aflatoxins could be dangerous for human

Gazi Üniversitesi, Eczacllk Fakültesi, Besin Analizleri Bilim Dalı, 06330, Etiler, ANKARA

İletişim/ Corresponding Author : Gülderen YENTÜR

Gazi Üniversitesi, Eczaclık Fakültesi, Besin Analizleri Bilim Dalı, 06330, Etiler, ANKARA

Tel : +903122023200_E-posta / E-mail : yentur@gazi.edu.tr

Geliş Tarihi/Received : 28.07.2011 Kabul Tarihi / Accepted : 16.11.2011

DOI ID : 10.5505/TurkHijyen.2012.54154

Yentür G, Er B. Gıdalarda aflatoksin varlığının değerlendirilmesi. Turk Hij Den Biyol Derg, 2012; 69(1): 41-52. 
hepatotoksik ve mutajenik karekteristiği nedeniyle insan hayatı için tehlikeli olabileceği belirtilmiștir. Bu nedenle aflatoksin kontaminasyonu gıda güvenliği açısından önemini korumaktadır. Yüksek miktarlarda aflatoksin içeren gıdaların uzun süre tüketimi halk sağlığı açısından problem yaratabileceği gibi aynı zamanda ihracatı da olumsuz yönde etkileyerek ülkede ekonomik kayıplara neden olabilecektir. Diğer birçok ülkede olduğu gibi Türkiye'de pek çok gıda maddesi için Aflatoksin $B_{1}\left(A_{F} B_{1}\right)$, Toplam Aflatoksin-TAF $\left(B_{1}, B_{2}, G_{1}\right.$ ve $\left.G_{2}\right)$ ve Aflatoksin $M_{1}$ $\left(A F M_{1}\right)$ ile ilgili yasal sınırlar belirlenmiștir. Bu derlemede, kanserojenik, teratojenenik, hepatotoksik ve mutajenik etkileri ile ön plana çıkan aflatoksinlerin gıdalardaki varlığı ve son yıllardaki kontaminasyon durumunun değerlendirilmesi amaçlanmıștır.

Anahtar Sözcükler: Aflatoksin, gıda, karsinojen, kontaminasyon, detoksifikasyon due to their toxic, carcinogenic, teratogenic, hepatoxic and mutagenic characteristic. Therefore, aflatoxins contamination remains of importance in terms of food safety. Long-term consumption of food containing high amounts of aflatoxin may result in health problems and adversely affect the export of several products and cause economic losses. In Turkey, similarly to other countries Aflatoxin $B_{1}\left(A F B_{1}\right)$, Total Aflatoxin-TAF $\left(B_{1}, B_{2}, G_{1}\right.$ and $\left.G_{2}\right)$ and Aflatoxin $M_{1} \quad\left(A F M_{1}\right)$ levels in food should be kept within the legal limits. The present review aimed to evaluate the emerging role of aflatoxin as carcinogenic, teratogenic, hepatoxic and mutagenic products present in food.

Key Words: Aflatoxin, food, carcinogen, contamination, detoxification

\section{GíRiş}

Mikotoksinler tarım ürünlerinde tarladan tüketime kadar olan aşamalarda, ekolojik koșullara bağlı olarak gelișen ve üreyen bazı alt-mantarların sekonder metabolitleridir. Bu toksinler belirli nem ve sıcaklık koșullarında Aspergillus, Penicillium ve Fusarium gibi bazı küfler tarafından olușturulurlar $(1,2)$. En sık karșılașılan mikotoksinler aflatoksin (AF), okratoksin, trikotesenler, zeranol, patulin, siklopiazonik asit ve fumonisin olarak sıralanabilir (2). Bilinen 400 mikotoksin arasında aflatoksinler insan sağlığı açısından en tehlikeli olanlardır (3). Mikotoksinler içerisinde önemli yere sahip bu toksinler, İngiltere'de çok sayıda kanatı hayvanın ölümü ile sonuçlanan “Turkey $X$ ” hastalığı sonucunda keșfedilmişlerdir. Yüz binden fazla hindi ve diğer çiftlik hayvanının ölümüyle sonuçlanan hindi hastalığı salgınları sonrasında aflatoksinler heterosiklik bileșikler ile bağlantılı bir grup olarak 1960 yılında bulunmuștur (4,5). Aflatoksinler, Aspergillus flavus, Aspergillus parasiticus ve Aspergillus nomius küfleri

tarafından üretilen toksik metabolitlerdir (1). A. parasiticus $\mathrm{AFB}_{1}, \mathrm{AFB}_{2}, \mathrm{AFG}_{1}$ ve $\mathrm{AFG}_{2}$ aflatoksinlerinin hepsini üretirken $A$. flavus nadiren $A F G_{1}$ ve $A F G_{2}$ üretmektedir (6).

Aflatoksinle kontamine yemlerin tüketimi hayvan sağlığını ve üretimini olumsuz etkilemektedir. Aynı zamanda bu hayvanların et, yumurta ve sütlerinin tüketimi de insan sağlığı açısından tehlike olușturmaktadır (7). Bu toksinler akut ölümlerden kronik hastalıklara kadar geniş aralıklarda etki gösterebilirler (8). Genellikle eser miktarlarda (izin verilen kalıntı düzeylerinin biraz üzerinde) bile etkili, uçuculuğu az, teknolojik ișlemlere ve sıcaklığa karșı dirençlidirler (9). Bu nedenle de pek çok ülkede gıdaların ve yemlerin mikotoksin ile kontaminasyonu belirli analiz programları ile izlenmektedir. Bu derlemede, kanserojenik, teratojenenik, hepatotoksik ve mutajenik etkileri ile ön plana çıkan aflatoksinlerin gıdalardaki varıı̆ı ve son yıllardaki kontaminasyon durumunun değerlendirilmesi amaçlanmıștır. 


\section{GIDALARINAFLATOKSINLERLE KONTAMINASYONU}

Ciftlik hayvanlarının beslenmesinde yararlanılan yemler yanında insanların beslenmesinde önemli bir yere sahip olan gida maddelerinin aflatoksin ile kontaminasyonu dünyanın çeșitli bölgelerinde sık karșılașılan bir durumdur. Dolayısıyla bu kontaminasyonlar hem gıda güvenliğini etkileyerek halk sağlığı açısından risk olușturmakta hem de tarım endüstrisinde önemli ekonomik kayıplara neden olmaktadır (3).

Aflatoksinler hasat, kurutma, depolama, gida ve yem halinde ürünü ișleme aşamasında oluşabildiği gibi ürün tarlada veya bahçede gelișirken de meydana gelebilmektedir. Aflatoksin oluşumunu ürün nemi, kurutma hızı, ortamın nisbi nemi, sıcaklık, ortamda bulunan fungus veya sporlarının yoğunluğu, gelișen türlerin toksin olușturma güçleri, mikroorganizmalar arası rekabet, ürünün ve yetiștirilen çeșidin direnci, böcek veya diğer zararlıların faaliyeti, bitki stresi, hava sıcaklı̆̆ı, atmosferik gazların bileșimi gibi birçok etken etkilemektedir (10).

Aflatoksinlerin gelișmesinde nisbi nem ve sıcaklık önemli parametrelerdir. Aflatoksijenik küflerin gelișmesi için optimum şartlar $24-35{ }^{\circ} \mathrm{C}$ ve \%70'in üzerindeki nisbi nemdir $(11,12)$. Ayrıca gidalarda aflatoksin üretimi ve misel gelişimi sıcaklık ve su aktivitesi (aw) ile kontrol edilmektedir. Diğer faktörler ise sıcaklık uygulaması, modifiye atmosfer paketleme ve koruyucu madde kullanımıdır (13). Bu nedenle hava veya günește kuruyan tahıl, pamuk, yerfıstığı ve fındık gibi tohumlarda yaygın bir kontaminanttır (14). Mısır da yetiștirme, hasat, depolama, tașıma ve işlem basamaklarında genellikle mikotoksine maruz kalan gidalardandır. Hasat öncesi ve sonrasında A. flavus ile enfekte olan misırlarda kurutma ve depolama koșullarının iyi olmaması halinde aflatoksin kontaminasyonunda artış görülmektedir (15).

Küf gelişimi için gerekli olan sıcaklık ve su aktivitesi (aw) değerleri toksin oluşumu için gereksinim duyulan değerler ile aynı olmamakta ve türe göre de değişiklik göstermektedir. Örneğin A. flavus'un gelișmesi ve mikotoksin üretiminde aw sırasıyla 0,73 ve 0,85 'dir. Bu durumda nem içeriği de $\% 8-12$ ve $\% 17-19$ 'dur (15).

Küf ve toksin oluşumu için gerekli minimum sıcaklık değerleri de farklıık göstermektedir. A. parasiticus'un gelișmesi için en düşük sıcaklık aralığı 6-8 ${ }^{\circ} \mathrm{C}$ iken 25-35 ${ }^{\circ} \mathrm{C}$ 'de optimum gelișme sağlanmaktadır. A. flavus için ise en iyi gelișme aralığı $19-35^{\circ} \mathrm{C}$ iken $12-42{ }^{\circ} \mathrm{C}$ arasında toksin üretmektedir $(15,16)$.

Aflatoksin kontaminasyonu hızlıca oluşabilmektedir. Yapılan bir çalıșmada, A. flavus inokule edilen bitkilerde iki gün sonra 0,3-2 ppb, dört gün sonra 950-2.800 ppb ve yedi gün sonra ise 3.600-4.500 ppb miktarlarında aflatoksin varlığına rastlandığı belirtilmiştir (17).

\section{GIDALARINAFLATOKSINLERLE DEKONTAMINASYONU} VEYAAFLATOKSINLERIN DETOKSIFIKASYONU

Aflatoksinler difuranokumarin yapısına sahip bileșiklerdir ve iki kimyasal grubu vardır. Bunlar $A F B_{1}, A F B_{2}, A F B_{2} A, A F M_{1}, A F M_{2}, A F M_{2} A$ ve aflatoksikol içeren difurokumarosiklopentanon serisi ile $A F G_{1}$ ve $\mathrm{AFG}_{2}$ 'i içeren difurakumarolakton serisidir (17). Yirmi aflatoksin türü tanımlanmasına rağmen bunlardan $A F B_{1}, A F B_{2}, A F G_{1}$ ve $A F G_{2}$ belli başlılarıdır. Bunlar kromatogramdaki hareketleri ve floresans özelliklerine göre adlandırılmaktadırlar. Ultraviyole ıșık altında mavi floresans verenler $\mathrm{AFB}_{1}$ ve $\mathrm{AFB}_{2}$, yeșil floresans verenler ise $A F G_{1}$ ve $A F G_{2}$ olarak adlandırılmaktadır (18-20). $\mathrm{AFB}_{1}$ ve $\mathrm{AFB}_{2}$ içeren yemlerle beslenen ineklerin sütünde rastlanan, ana moleküle benzer fakat daha az biyolojik etki gösteren türevler ise AFM ve $\mathrm{AFM}_{2}$ olarak adlandırılmaktadır $(19,20)$.

$\mathrm{AFB}_{1}$ molekülünün fizikokimyasal ve biyokimyasal özellikleri incelendiğinde toksikolojik affinitesinde iki önemli bölge vardır. İlk bölge furofuran halkasının c-8, 9 pozisyonunda ki çift bağdır ve aflatoksinin DNA ve protein etkileșimlerine neden olmaktadır. ikinci reaktif grup ise kumarin fonksiyonel grubuna bağlı lakton halkasıdır. Bu halka kolay hidrolize olur. Bu yüzden de degradasyon için zayıf bölgedir (21). 
Aflatoksinlerin yapisal degradasyonu veya inaktivasyonu kimyasallarla mümkündür. Özellikle de sodyum hipoklorit, klorindioksit, klorin gazı, hidrolitik ajanlardan organik ve inorganik asitler ve sodyum hidroksit, amonyum hidroksit ve potasyum hidroksit gibi alkaliler ile degradasyon sağlanabilmektedir $(21,22)$. Bu kimyasalların bir kısmı gıda endüstrisinde kullanılmasına rağmen çoğu toksik kalıntı bıraktığından, besin içeriğine zarar verdiğinden, tat, koku, renk, tekstür ve ürünün fonksiyonel özelliklerini etkilediğinden kullanılmaları uygun değildir (21). İnsan gıdalarının ve hayvan yemlerinin kontaminasyonunun fiziksel, kimyasal ve biyolojik metotlarla kontrolü ile ilgili birçok çalıșma mevcuttur. Bunlar toksini daha az mutajenik etkili ve daha az zararlı hale dönüștürmek içindir. Bu kimyasallar asitler, oksitleyici ajanlar, bisülfitler ve gazlardır (23). Mikrodalga ile ısıtma, ozon ile muamele (ozonlama) veya amonyak gibi birçok fiziksel ve kimyasal yöntemler aflatoksin ile kontamine olmuş gıdaların detoksifikasyonu için tavsiye edilmektedir. Son zamanlarda gıdalarda aflatoksin detoksifikasyonu için bir oksidasyon yöntemi olan ozonlama geliștirilmiștir. Ozon veya triatomik oksijen $\left(\mathrm{O}_{3}\right)$, güçlü bir dezenfektan ve oksitleyici ajandır (24).

Mikotoksinler, radyasyon dozuna bağlı olarak gıda ve mikotoksinin tipine göre gama $(\gamma)$ ıșınları radyasyonu ile inaktive olabilmektedirler. Bununla birlikte $\gamma$-radyasyon ile aflatoksinlerin bozunmasında su aktivitesi kritik rol oynamaktadır. Rustom (4) 1 ve 10 kGy dozunda $Y$-ıșıını uygulanan yerfıstığı örneklerinde sırasıyla \%75 ve \%100 azalma görüldüğünü belirtmiștir. Aflatoksinler 222, 265 ve 362 nm'de UV radyasyonuna duyarlıdırlar. En büyük absorpsiyonu ise 362 nm'de göstermektedir. $1 \mathrm{ppb} \mathrm{AFM}_{1}$ ile kontamine süt örneklerine 20 dakika $365 \mathrm{~nm}$ radyasyon uygulandığında \%56,2'sinin yıkımlandığı bildirilmiștir $(4,25,26)$. Mikroorganizmalarla aflatoksin detoksifikasyonuna ilișkin çalıșmalarda bulunmaktadır. Thanaboripat ve ark., (27) yaptıkları çalıșmada, ticari olarak üretilen yoğurtlarda laktik asit bakterileri ve
Streptococcus lactisileaflatoksinin detoksifikasyonunu araștırmışlardır. Sonuç olarak da, S. lactis ile AFB düzeyinin 50'den 33,70 $\mu \mathrm{g} \mathrm{ml}^{-1}$ 'ye düștüğünü ve laktik asit bakterilerine göre detoksifikasyon için daha yetenekli olduklarını belirtmișlerdir.

Dekontaminasyon veya detoksifikasyon ișlemi mikotoksin ile kontamine olan besin maddeleri açısından yararlıdır. İdeal dekontaminasyon işlemi ucuz ve uygulaması kolay olmalı, toksik metabolit oluşumuna yol açmamalıdır. Yem ve gıda maddelerinde besinsel ve tat özelliklerini değiștirebilecek ve yeni mikotoksin oluşumuna yol açabilecek özellikte olmamalıdır. Bu nedenle mikotoksin kontaminasyonunun önlenmesi daha önemlidir $(21,28)$.

\section{AFLATOKSINLERIN VÜCUDA ALINMASI VE ETKILERI}

Mikotoksinler insanlara kontamine besinler ve kontamine yemlerle beslenen hayvanlardan elde edilen ürünler aracılığıyla kalıntı düzeylerinde de olsa ulașırlar. Az gelișmiș veya gelișmekte olan ülkelerde besinlerin yaklaşık \%25'inin mikotoksinlerle ve metabolitleriyle kontamine olduğu görülmektedir (9). Mikotoksinler genellikle kontamine gıdanın tüketilmesi ile vücuda alınıyor olsa da toksijenik sporların inhalasyonu ve doğrudan deri ile temas diğer maruziyet yollarıdır (29). Dünyanın değişik yerlerinde insanların günlük aflatoksin alım miktarları 0-30.000 ng kg-1 arasında değișmektedir (19).

İnsanlar diyet ile düșük miktarda toksine maruz kalabilmektedir. Uzun vadede düșük dozda aflatoksine maruz kalınması çok tehlikeli sonuçlara neden olabilmektedir $(30,31)$. Aflatoksine maruziyet durumu, kişinin yașı, beslenme düzeni, hepatit $B$ enfeksiyonu gibi bazı sağlık faktörleri aflatoksinlerin toksisite derecesini etkilemektedir (32).

Aflatoksinlerin insan ve hayvanlarda oluşturduğu akut ve kronik seyirli mikotoksikoza aflatoksikoz adı verilmektedir (32). Ayrıca aflatoksinlerin siroz, 
hepatit, kronik gastrit, Reye sendromu ve böbrek hastalıklarına neden olabildiği belirtilmektedir (33). Bununla birlikte, aflatoksinlerin çocuklarda Kwashiorkor hastalığı ile bağlantılı olduğu da bildirilmektedir (4). Aflatoksin insan kordon kanında bulunmuștur ve bu durumda gelișmekte olan fetüse de geçebilmektedir (19). Ayrıca mikotoksinler hayvanlarda verim kaybı, ağırlık artıșında azalma, immunosupresyon ve kanser oluşumuna neden olabilmektedirler. Bulașmıș yemlerle beslenen hayvanlarda zehirlenmeler olușabilmektedir (31).

Aflatoksinler olușturdukları toksik etki gücüne göre $A F B_{1}>A F G_{1}>A F B_{2}>A F G_{2}$ șeklinde sıralanmaktadır (17). $\mathrm{Bu}$ toksinler içerisinde $A F B_{1}$ 'in insan sağlığı açısından en toksik ve en yaygın olduğu belirtilmektedir $(33,34)$. Aflatoksinler akut ve kronik toksisiteye ve büyük bir bölümü ise karsinojenik, mutajenik ve teratojenik etkiye sahiptirler (35). Uluslararası Kanser Araștırma Kuruluşu (International Agency of Research on CancerIARC) tarafından AFB ${ }_{1}$ Grup 1 karsinojen, AFM ise Grup 2 karsinojen olarak bildirilmiștir (36). AFB ' in toksik ve karsinojenik etkileri için temelde hedef organlar karaciğer ve böbrektir. Aflatoksinin hepatotoksik, hepatokarsinojenik ve teratojenik etkileri farkl hayvan türlerinde gösterilmiștir (37). AFB 1 rat, fare, maymun, marmoset, ördek, lepistes, somon, alabalık ve kır faresi gibi bazı hayvanlarda malignant tümör olușumunu indükleyebilmektedir. Bu bileșikler için hedef organ karaciğer olmakla beraber bazı ratlarda böbrek ve intestinal tümörler görülebilmektedir (38). Bununla birlikte hepatokarsinoma gelișiminde aflatoksinlerin etkili olabileceği belirtilmektedir $(39,40)$. Türkiye'de yapılan bir çalıșmada viral hepatit hastalarında sağlıklı bireylere göre aflatoksin maruziyetinin yüksek olduğu ve bu durumun hepatosellüler karsinoma gelișiminde önemli bir rol oynayabileceği belirtilmiștir (41). Mikotoksin zehirlenmelerinde etkin bir tedavi yöntemi yoktur. Kontamine olan besinlerin mikotoksinlerden arındırılması da olası görünmemektedir. Bu nedenle, insan sağlığı bakımından kontamine gıdaların tüketiminden kaçınılması ve gıdaların kontaminasyonuna karșı etkin önlemlerin alınması önemlidir (9).

GIDALARDA AFLATOKSIN VARLIĞI VE YASAL DÜZENLEMELER

Aflatoksinler dünyada çiğ olarak tüketilen gıdalardan özellikle yerfıstığı, fındık, kakao, kahve, mısır, pirinç, buğday ve diğer tahıl ürünleri ile kuru meyvelerde yaygın șekilde oluşmaktadır $(21,42,43)$. Aynı zamanda süt ve süt ürünleri, kırmızı biber ve kırmızı biber ürünleri gibi baharatlar da dahil olmak üzere pek çok gıdada yaygın olarak bulunabilmektedir $(42,44,45)$. Yüksek miktarlarda aflatoksin içeren gıdaların uzun süre tüketimi halk sağıı̆̆ı açısından problem yaratabileceği gibi aynı zamanda ihracatı da olumsuz yönde etkileyebileceğinden ülkede ekonomik kayıplara neden olabilmektedir. Bu yüzden mikotoksinlerin gelișiminin üretimden tüketime kadar izlenebilirliği önem tașımaktadır (21,43). Yapılan araștırmalar sonucunda; Türkiye'de tüketime sunulan bazı gıda maddelerine ait belirlenen aflatoksin düzeyleri Tablo 1'de sunulmuștur (31, 42-62). $\mathrm{Bu}$ değerler incelendiğinde; gıda çeșidi, bölgesel ve mevsimsel özellikler gibi faktörlerin etkisiyle farklılıkların bulunduğu görülmüștür.

Türkiye' de diğer birçokülkede olduğu gibi gıdalarda aflatoksin kontaminasyonu ile ilgili yasal kısıtlamalar vardır. Avrupa Birliğine uyum süreci çerçevesinde hazırlanan 2008/26 sayılı gıda maddelerindeki bulașanların maksimum limitleri hakkındaki Türk Gıda Kodeksi (TGK) Tebliğinde pek çok gıda maddesi için $A F B_{1}$, toplam Aflatoksin-TAF $\left(B_{1}, B_{2}, G_{1}\right.$ ve $\left.G_{2}\right)$ ve AFM ile ilgili sınırlar belirtilmiștir (63).

Asya ülkelerinin birçoğunda pirinç aflatoksin sıklığı ve kontaminasyonunda temel gıdadır. Ayrıca arpa ve misır bazlı gıdalarda da aflatoksin varlığı bildirilmiștir (64). Özellikle tohumlarda yüksek miktarlarda aflatoksin olduğu bilinmektedir. Yerfıstığının depolanmasında nem \%8'in ve ortam sıcaklığı 25 'C'nin üzerinde ise aflatoksin olușturan küfler meydana gelmektedir (17). 
Tablo 1. Türkiye'de tüketime sunulan bazı gıda maddelerine ait aflatoksin düzeyleri

\begin{tabular}{|c|c|c|c|c|}
\hline Örnek & $\begin{array}{l}\text { Örnek Miktarı } \\
\text { (Pozitif Örnek) }\end{array}$ & Aflatoksin Türü & Aflatoksin Düzeyleri & Kaynak \\
\hline \multirow{5}{*}{ Yerfıstığı ve ürünleri } & $85(1)$ & $\mathrm{AFB}_{1}$ & $21 \mathrm{ppb}$ & Özay ve Alperden (46) \\
\hline & $22(5)$ & $\mathrm{AFB}_{1}$ & 1,2-11,3ppb & Gürses ve Erdoğan (47) \\
\hline & $18(7)$ & $\mathrm{AFB}_{1}$ & 8-94 ppb & Gürses (48) \\
\hline & 20 & TAF & $8,16-75,74$ ng g $^{-1}$ & Yentür ve ark. (43) \\
\hline & $10(5)$ & TAF & $0,75-26,36 \mu \mathrm{g} \mathrm{kg}^{-1}$ & Bircan ve ark. (49) \\
\hline \multirow{3}{*}{ Fındık ve ürünleri } & $91(81)$ & $\mathrm{AFB}_{1}$ & $<1-13 \mathrm{ppb}$ & Ayçiçek ve ark. (50) \\
\hline & $28(9)$ & $\mathrm{AFB}_{1}$ & $1-113 \mathrm{ppb}$ & Gürses (48) \\
\hline & $80(2)$ & TAF & $5,46-6,55 \mu \mathrm{g} \mathrm{kg}^{-1}$ & Bircan ve ark. (49) \\
\hline \multirow{2}{*}{ Badem } & $9(2)$ & $\mathrm{AFB}_{1}$ & 2,9-4,7 ppb & Gürses ve Erdoğan (47) \\
\hline & $13(3)$ & $\mathrm{AFB}_{1}$ & $1-13 \mathrm{ppb}$ & Gürses (48) \\
\hline Ceviz & $24(6)$ & $\mathrm{AFB}_{1}$ & 3-28 ppb & Gürses (48) \\
\hline Misır & 26 & TAF & $0,01-32,30 \mu \mathrm{g} \mathrm{kg}^{-1}$ & Oruç ve ark. (51) \\
\hline İncir & 103 & $\mathrm{AFB}_{1}$ & $0-63,0 \mu \mathrm{g} \mathrm{kg}^{-1}$ & Özay ve Alperden (52) \\
\hline Leblebi & $11(1)$ & $\mathrm{AFB}_{1}$ & $1-2 \mathrm{ppb}$ & Gürses (48) \\
\hline Baharat & $84(36)$ & TAF & $0,3-46,8 \mu \mathrm{g} \mathrm{kg}^{-1}$ & Çolak ve ark. (42) \\
\hline Buğday & $41(24)$ & TAF & $10,4-643,5 \mathrm{ng} / \mathrm{kg}$ & Giray ve ark. (53) \\
\hline Buğday unu & $50(37)$ & TAF & $1,75-<4$ ppb & Özturan ve ark. (31) \\
\hline \multirow{2}{*}{ Fistık } & $13(3)$ & $\mathrm{AFB}_{1}$ & $1,1-1,5 \mathrm{ppb}$ & Gürses ve Erdoğan (47) \\
\hline & $28(16)$ & TAF & $2,31-63,11 \mu \mathrm{g} \mathrm{kg}^{-1}$ & Bircan ve ark. (49) \\
\hline \multirow{4}{*}{ Kırmızıbiber ve ürünleri } & 100 & $\mathrm{AFB}_{1}$ & $<0,025-40,9 \mu \mathrm{g} \mathrm{kg}{ }^{-1}$ & Aydın ve ark. (54) \\
\hline & $75(72)$ & $\mathrm{AFB}_{1}$ & $0,11-24,7 \mu \mathrm{g} \mathrm{kg}^{-1}$ & Ardıç ve ark. (44) \\
\hline & $23(19)$ & TAF & $1,79-6,55 \mu \mathrm{g} \mathrm{kg}{ }^{-1}$ & Bircan ve ark. (49) \\
\hline & 190 & $\mathrm{AFB}_{1}$ & $0,20-6,12 \mathrm{ppb}$ & Yentür (55) \\
\hline \multirow{2}{*}{ Susam } & 2 & TAF & - & Demirer ve ark. (56) \\
\hline & 20 & $\mathrm{AFG}_{1}$ & $0,06-2,04 \mathrm{ng} \mathrm{g}^{-1}$ & Yentür ve ark. (43) \\
\hline Helva & $102(8)$ & $\mathrm{AFB}_{1}$ & $1,5-18 \mu \mathrm{g} \mathrm{kg}^{-1}$ & Var ve ark. (57) \\
\hline \multirow{2}{*}{ Süt } & $27(16)$ & $\mathrm{AFM}_{1}$ & $10-50,5 \mathrm{ng} \mathrm{L}^{-1}$ & Gürbay ve ark. (58) \\
\hline & 220 & $\mathrm{AFM}_{1}$ & $0-0,26 \mathrm{ppb}$ & Er ve ark. (45) \\
\hline \multirow{5}{*}{ Süt Ürünleri } & $400(327)$ & $\mathrm{AFM}_{1}$ & $51->800 \mathrm{ng} \mathrm{kg}^{-1}$ & Sarımehmetoğlu ve ark. (59) \\
\hline & $63(28)$ & $\mathrm{AFM}_{1}$ & $7-202 \mathrm{ng} \mathrm{kg}^{-1}$ & Gürses ve ark. (60) \\
\hline & $80(50)$ & $\mathrm{AFM}_{1}$ & 1- >601 $\mathrm{ng} \mathrm{kg}^{-1}$ & Elmalı ve ark. (61) \\
\hline & 193 (159) & $\mathrm{AFM}_{1}$ & $52-860 \mathrm{ng} \mathrm{kg}^{-1}$ & Ardiç ve ark. (62) \\
\hline & 70 & $\mathrm{AFM}_{1}$ & $0-0,24 \mathrm{ppb}$ & Er ve ark. (45) \\
\hline
\end{tabular}


Türk Gıda Kodeksi Tebliğinde, doğrudan tüketime sunulmadan veya gıda bileșeni olarak kullanılmadan önce sınıflandırma, ayıklama gibi fiziksel ișlemlere tabi tutulan yerfıstıklarında maksimum $\mathrm{AFB}_{1}$ ve toplam aflatoksin miktarlarının sırasıyla 8 ve $15 \mu \mathrm{g}$ $\mathrm{kg}^{-1}$ olabileceği belirtilmiștir. Aynı Tebliğde tahıllar (karabuğday - Fagopyrum sp. dahil) ve bunlardan üretilen ișlenmiș gıdaların maksimum $A_{F} B_{1}$ ve toplam aflatoksin miktarları sırasıyla 2 ve $4 \mu \mathrm{g} \mathrm{kg}{ }^{-1}$ olarak bildirilmiștir (63). Ayrıca fındık, antepfıstığı gibi sert kabuklu meyveler, yer fıstığı, yağlı tohumlar, kuru meyveler ve bunlardan üretilen ișlenmiş gıdalar için maksimum toplam aflatoksin miktarı da $10,0 \mu \mathrm{gg}^{-1}$ olarak belirtilmiștir (65).

Bașaran ve Özcan (66) yaptıkları çalıșmada 217 kuruyemiş örneğinde $A F B_{1}, A F B_{2}, A F G_{1}$ ve $A F G_{2}$ miktarlarını araștırmıșlardır. Örneklerin \%14,28'inde düşük miktarlarda ve \%1,84'ünde de sınır değerlerinin üstünde aflatoksin saptamıșlardır.

Bircan ve ark., (49) yaptıkları çalıșmada 2.643 kuru yemiș örneğinin 313 tanesinde, 80 adet fındığın ikisinde, 28 fıstığın 16'sında ve 10 yerfıstığının beșinde ve 23 biberin 19'unda sırasıyla $0,2-162,76 ; 5,46-6,55 ; 2,31-63,11 ; 0,75-26,36$ ve 1,79-6,55 $\mu \mathrm{g} \mathrm{kg}^{-1}$ oranlarında toplam aflatoksin saptamıșlardır.

Süt ve süt ürünleri insanlar özellikle de çocuklar için hayvansal protein, kalsiyum, vitamin ve esansiyel yağ asidi gibi besin maddeleri için iyi bir kaynaktır. Fakat süt ve süt ürünleri aynı zamanda aflatoksinler açısından da potansiyel kaynaktırlar (67). AFB ${ }_{1}$ in alınmasından 12-24 saat sonrasında sütte $A_{1} M_{1}$ saptanabilmektedir. Süt bazlı diğer ürünlerde de AFM ürün ișlenme basamaklarından etkilenmemektedir (58). Bununla birlikte, AFM süte uygulanan pastörizasyon ișlemine dayanıklıdır (67). Süt ve süt ürünleri açısından getirilen yasal kısıtlamalarda; çiğ süt, ısıl ișlem görmüș süt ve süt bazlı ürünlerin üretiminde kullanılan sütlerde maksimum $\mathrm{AFM}_{1}$

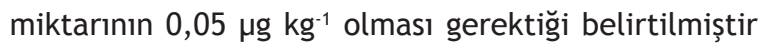
(63).
Bebek ve küçük çocuk ek gıdaları için ise maksimum $\mathrm{AFB}_{1}$ miktarı 0,10 $\mu \mathrm{g}$ kg-1 olarak belirtilmiștir. Ayrıca, bebek mamalarında (bebek sütleri ve devam sütleri dahil) maksimum AFM $0,025 \mu \mathrm{g} \mathrm{kg}{ }^{-1}$, bebeklerin özel tıbbi amaçlı diyet gıdalarında maksimum AFB ve $A F M_{1}$ sirasiyla $0,10 \mu \mathrm{gg}^{-1}$ ve $0,025 \mu \mathrm{gg}^{-1}$ olarak bildirilmektedir. Aflatoksin bulunması muhtemel riskli gıdalar için ise genel olarak maksimum değerler $\mathrm{AFB}_{1}$, toplam aflatoksin ve $\mathrm{AFM}_{1}$ için sırasıyla $5,0,10,0$ ve $0,5 \mu \mathrm{gg}^{-1}$ olarak belirtilmiștir (63). Virdis ve ark., (68) İtalya'da keçi sütü ve keçi sütünden yapılan peynirlerde $\mathrm{AFM}_{1}$ kontaminasyonunu araștırmıșlardır. 41 peynir örneğinin 4 (\% 9,8)'ünde

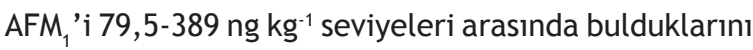
belirtmișlerdir.

Torkar ve Vengust (69) Slovenya'da yaptıkları çalıșmada çiğ süt ve peynir örneklerinde maya, küf ve $A F M_{1}$ varı̆ı̆ını araștırmıșlardır. Peynir örneklerinin 4 (\% 10)'ünde AFM, seviyesinin $51-223 \mathrm{ng} \mathrm{kg}^{-1}$ arasında olduğunu belirtmișlerdir.

Bununla birlikte biber, zerdeçal, karabiber, kișniş ve kuru zencefil gibi baharatlarda hasat öncesi, hasat sonrası, depolama ve tașıma sırasında kontamine olabilmektedir (3). Türk Gıda Kodeksi Tebliğinde baharatlardan kırmızıbiber (Capsicum spp.), karabiber (Piper spp.), hintcevizi/muskat (Myristica fragrans), zencefil (Zingiber officinale), zerdeçal (Curcuma longa) gibi ürünlerde maksimum $\mathrm{AFB}_{1}$ ve toplam aflatoksin miktarları sırasıyla 5,0 ve $10,0 \mu \mathrm{gg}^{-1}$ olarak belirtilmiștir (63). Tüketimi çok olan gıdalardan biri de kırmızıbiber ve ürünleridir. Kırmızıbiber dünyada tüketimi yaygın olan çok popüler bir baharattır (70). Türkiye de Hindistan, Meksika, Amerika, İspanya gibi yüksek miktarda kırmızıbiber üreten ülkelerden birisidir. Kırmızı toz biberler Türkiye'de yemeklerin rengi, lezzeti ve aroması için çok sık kullanılan baharat çeșitleridir (54). Kırmızıbiber; üretim, hasat, kurutma ve daha sonraki ișleme safhalarında karșı karșıya kaldığı șartlar nedeniyle aflatoksin olușumuna hassas ürünlerden birisidir (44). 
Kırmızıbiber en yüksek oranda aflatoksin içeren baharat türüdür (71). Bu biberlerin mikotoksinler ile kontaminasyonunda bölgenin iklimi, ürün genotipi ve toprak tipi gibi birçok faktör etkilidir (72).

Dünyadaki en fazla biber üreticisi olan ülkeler tropik bölgelerde bulunmaktadır. Dolayısıyla kırmızıbiber ve ürünlerinde mikotoksin üreten küflerin gelișimi için uygun iklim koșulları bulunmaktadır (71). Bununla beraber biberler genellikle yetersiz hijyenik koșullar altında açık havada kurutulmaktadır (44). Kırmızıbiberler de diğer pek çok ürün gibi aflatoksinler ile hasat öncesinde, hasat sonrasında, depolama sırasında ve taşıma esnasında kontamine olabilmektedir $(71,72)$. Gıda maddelerindeki bulașanların maksimum limitleri hakkındaki 2008/26 sayılı Türk Gıda Kodeksi Tebliğinde, tüm ve toz kırmızıbiberler için maksimum $\mathrm{AFB}_{1}$ ve total aflatoksin miktarının sırasıyla $5 \mu \mathrm{g} \quad \mathrm{kg}^{-1}$ ve $10 \mu \mathrm{gg} \mathrm{kg}^{-1}$ olduğu belirtilmiștir (63). Türk Gıda Kodeksi Tebliği, 1881/2006/EC sayılı gıda maddelerindeki belirli bulașanların maksimum miktarlarının belirlenmesi hakkında komisyon tüzüğü dikkate alınarak Avrupa Birliği'ne uyum süreci çerçevesinde hazırlanmıștır. Bu direktif 2010 yılında çıkan 165/2010 direktifi ile yeniden düzenlenmiștir $(73,74)$.

\section{KAYNAKLAR}

1. Zinedine A, González-Osnaya L, Soriano JM, Moltó JC, Idrissi L, Mañes J. Presence of aflatoxin M1 in pasteurized milk from Morocco. Int J Food Microbiol, 2007; 114 (1): 25-9.

2. Kumar V, Basu MS, Rajendran TP. Mycotoxin research and mycoflora in some commercially important agricultural commodities. Crop Prot, 2008; 27 (6): 891-905.

\section{SONUÇ}

Gida maddelerinin ve hayvan yemlerinin aflatoksinler ile kontaminasyonu dünya genelinde ciddi bir problemdir. Aflatoksinlerle kontamine olmuş gıdayı tüketen insanlarda ölümle sonuçlanabilen hastalıklar meydana gelebilmektedir. Farklı ülkelerde, çeșitli gıdalarda aflatoksin varlığının araștırıldığı çalıșmalar yapılmıștır. Bu araștırmalardaki aflatoksin düzeyleri iklimsel ve bölgesel nedenlerle veya gıda çeșidine göre farklılıklar gösterebilmektedir. Ayrıca mikrobiyolojik ve kimyasal detoksifikasyonla ilgili çalıșmalar incelendiğinde ise bazılarında aflatoksin düzeylerinde belli miktarda azalma görülmektedir. Fakat bu durum detoksifikasyonun yeterli olmadığı șeklinde değerlendirilmektedir.

Aflatoksinlerin sağlık üzerine olumsuz etkileri ve ülke ekonomisi açısından kayıplar düșünüldüğünde izlenebilirliğin önemli olduğu görülmektedir. Gıdaların ve hayvan yemlerinin üretimden tüketime kadar her așamada aflatoksin yönünden analitik yöntemlerle analizleri yapılarak kontrolleri sağlanmalıdır. Yasal düzenlemeler doğrultusunda kabul edilen sınırlardan daha yüksek değerlerde aflatoksin içeren gıda ve yemlerin tüketilmesine izin verilmemelidir. Gıda ve yemlerin küflerle kontaminasyonunun önlenebilmesi ve dolayısıyla aflatoksin olușumunun engellenebilmesi yönünde çalıșmaların artırılması gerekmektedir. Ayrıca aflatoksinin detoksifikasyonunun yeterli olmamasından dolayı kontaminasyonun kontrol altında tutulması önem tașımaktadır.

3. O'Riordan MJ, Wilkinson MG. A survey of the incidence and level of aflatoxin contamination in a range of imported spice preparations on the Irish retail market. Food Chem, 2008; 107 (4): 1429-35.

4. Rustom IYS. Aflatoxin in food and feed: Occurrence, legislation and inactivation by physical methods. Food Chem, 1997; 59 (1): 57-67. 
5. Farombi EO. Aflatoxin contamination of foods in developing countries: implications for hepatocellular carcinoma and chemopreventive strategies. Afr J Biotechnol, 2006; 5 (1): 001-14.

6. Wright MS, Greene-McDowelle DM, Zeringue HJ, Bhatnagar D, Cleveland TE. Effects of volatile aldehydes from Aspergillus-resistant varieties of corn on Aspergillus parasiticus growth and aflatoxin biosynthesis. Toxicon, 2000; 38 (9): 1215-23.

7. Gowda NKS, Malathi V, Suganthi RU. Effect of some chemical and herbal compounds on growth of Aspergillus parasiticus and aflatoxin production. Anim Feed Sci Tech, 2004; 116 (3-4): 281-91.

8. Móricz AM, Fatér Z, Otta KH, Tyihák E, Mincsovics E. Overpressured layer chromatographic determination of aflatoxin $B_{1}, B_{2}, G_{1}$ and $G_{2}$ in red paprika. Microchem J, 2007; 85 (1): 140-4.

9. Şener S. Gıda güvenliği açısından mikotoksinler. Türkiye Klinikleri J Surg Med Sci, 2006; 2 (46): 135-9.

10. Çoksöyler N. Farklı yöntemlerle kurutulan kırmızıbiberlerde Aspergillus flavus gelișimi ve aflatoksin olușumunun incelenmesi. Gıda, 1999; 24 (5): 297- 306

11. Arrus K, Blank G, Abramson D, Clear R, Holley RA. Aflatoxin production by Aspergillus flavus in Brazil nuts. J Stored Prod Res, 2005; 41 (5): 513-27.

12. Odoemelam SA, Osu C I. Aflatoxin $\mathrm{B}_{1}$ contamination of some edible grains marketed in Nigeria. E-J Chem, 2009; 6 (2): 308-14.

13. Molina M, Giannuzzi L. Modelling of aflatoxin production by Aspergillus parasiticus in a solid medium at different temperatures, $\mathrm{pH}$ and propionic acid concentrations. Food Res Int, 2002; 35 (6): 585-94.

14. Bonjar GHS. Incidence of aflatoxin producing fungi in early split pistachio nuts of Kerman, Iran. J Biol Sci, 2004; 4 (2): 199-202.

15. Giorni P, Battilani P, Pietri A, Magan N. Effect of aw and $\mathrm{CO} 2$ level on Aspergillus flavus growth and aflatoxin production in high moisture maize postharvest. Int J Food Microbiol, 2008; 122 (1-2): 109-13.
16. Bhat R, Rai RV, Karim AA. Mycotoxins in food and feed: present status and future concerns. Compr Revi Food Sci F, 2010; 9 (1): 57-81.

17. Coppock RW, Christian RG. Aflatoxins. In: Gupta RC, ed. Veterinary Toxicology: Basic and Clinical Principles. New york: Academic Press, 2007: 939-50.

18. Zheng Z, Humphrey CW, King RS, Richard JL. Validation of an ELISA test kit for the detection of total aflatoxins in grain and grain products by comparison with HPLC. Mycopathologia, 2005; 159 (2): 255-63.

19. Verma RJ. Aflatoxin cause DNA damage. Int J Hum Genet, 2004; 4 (4): 231-6.

20. Reddy BN, Raghavender CR. Outbreaks of aflatoxicoses in India. Ajfns, 2007; 7 (5): 1-15.

21. Banu N, Muthumary J. Taxol as chemical detoxificant of aflatoxin produced by Aspergillus flavus isolated from sunflower seed. Health, 2010; 2 (7): 789-95.

22. Samarajeewa V, Sen AC, Cohen MD, Wei $\mathrm{Cl}$. Detoxification of aflatoxins in foods and feeds by physical and chemical methods. J Food Protect, 1990; 53(6), 489-501.

23. Safara M, Zaini F, Hashemi SJ, Mahmoudi M, Khosravi AR, Shojai-Aliabadi F. Aflatoxin detoxification in rice using citric acid. Iranian J Publ Health, 2010; 39 (2): 24-9.

24. Inan F, Pala M, Doymaz I. Use of ozone in detoxification of aflatoxin $B_{1}$ in red pepper. J Stored Prod Res, 2007; 43 (4): 425-9.

25. Yousef $A E$, Marth $E H$. Use of ultraviolet energy to degrade aflatoxin $M_{1}$ in raw or heated milk with and without added peroxide. J Dairy Sci, 1986; 69 (9): 2243-7.

26. Kabak B, Dobson ADW, Vara I. Strategies to prevent mycotoxin contamination of food and animal feed: a review. Crit Rev Food Sci Nutr, 2006; 46 (8): 593-619. 
27. Thanaboripat D, Kraipeerapun K, Pattanaphongsak C, Srisanan S, Nanasombat S. Detoxification of aflatoxin by Streptococcus lactis and lactic acid bacteria in commercial yoghurt. Kasetsart J-Nat Sci, 1997; 31: 117-23.

28. Leibetseder J. Decontamination and detoxification of mycotoxins. In: Mosenthin R, Zentek J, Zebrowska T, eds. Biology of Nutrition in Growing Animals. Elsevier Limited, 2006: 439-65.

29. Salem NM, Ahmad R. Mycotoxins in food from Jordan: Preliminary survey. Food Control, 2010; 21 (8): 1099-103.

30. Papp E, H-Otta K, Záray G, Mincsovics E. Liquid chromatographic determination of aflatoxins. Microchem J, 2002; 73 (1-2): 39-46.

31. Özturan K, Ünsal C, Karakaya Y, Atasever M, Ceylan ZG, Atasever MA. Erzurum'da tüketime sunulan buğday unlarının toplam aflatoksin, aflatoksin.B1 ve Okratoksin A Yönünden İncelenmesi. Atatürk Üniversitesi Vet Bil Derg, 2007; 2 (4): 172-6.

32. Sabuncuoğlu SA, Baydar T, Giray B, Şahin G. Mikotoksinler: Toksik etkileri, degredasyonları, olușumlarının önlenmesi ve zararlı etkilerinin azaltılması. Hacettepe Üni Ecz Fak Derg, 2008; 28 (1): 63-92.

33. Koirala P, Kumar S, Yadav BK, Premarajan KC. Occurrence of aflatoxin in some of the food and feed in Nepal. Indian J Med Sci, 2005; 59 (8): 331-6.

34. Hussain HS, Brasel JM. Toxicity, metabolism, and impact of mycotoxins on humans and animals. Toxicology, 2001; 167 (2): 101-34.

35. Oveisi MR, Jannat B, Sadeghi N, Hajimahmoodi $M$, Nikzad A. Presence of aflatoxin $M_{1}$ in milk and infant milk products in Tehran, Iran. Food Control, 2007; 18: 1216-8.

36. Anonymous. Some naturally-occurring substances: food items and constituents, heterocyclic aromatic amines and mycotoxins. Lyon: IARC monographs, 1993; 56: 359-62.

37. Ayub MY, Sachan DS Dietary factors affecting aflatoxin $B_{1}$ carcinogenicity. Mal J Nutr, 1997; 3: 161-79.
38. Singh VP. Aflatoxin biotransformations: Biodetoxification aspects. Prog Ind Microbiol, 1995; 32: 51-61.

39. Liu Y, Wu F. Global burden of aflatoxin-induced hepatocellular carcinoma: a risk assessment. Environ Health Perspect, 2010; 118 (6): 818-24.

40. Galy O, Chemin I, Le Roux E, Villar S, Le CalvezKelm F, Lereau M. Mutations in TP53 and CTNNB1 in relation to hepatitis $B$ and $C$ infections in hepatocellular carcinomas from Thailand. Hepat Res Treat, 2011; 2011: 1-9.

41. Mızrak D, Engin B, Onder FO, Yener B, Bektaș M, Biyikli Z, Idilman R. Aflatoxin exposure in viral hepatitis patients in Turkey. Turk J Gastroenterol, 2009; 20 (3): 192-7.

42. Çolak H, Bingol EB, Hampikyan H, Nazlı B. Determination of aflatoxin contamination in redscaled, red and black pepper by ELISA and HPLC. J Food Drug Anal, 2006; 14 (3): 292-6.

43. Yentür G, Er B,Gür Özkan $M$, Öktem BA. Determination of aflatoxins in peanut butter and sesame samples using high-performance liquid chromatography method. Eur Food Res Technol, 2006; 224 (2): 167-70.

44. Ardıç $M$, Karakaya $Y$, Atasever $M$, Durmaz $H$. Determination of aflatoxin $B_{1}$ levels in deep-red ground pepper (isot) using immunoaffinity column combined with ELISA. Food Chem Toxicol. 2008; 46: 1596-9.

45. Er B, Demirhan B, Onurdağ FK, Yentur G. Determination of aflatoxin $M_{1}$ level in milk and white cheese consumed in Ankara Region, Turkey. J Anim Vet Adv, 2010; 9 (12): 1780-4.

46. Özay G, Alperden ì. Türkiye'de yetiștirilen yerfıstıklarında (Arachis hypogaea L.) mikotoksinler. Gıda, 1989; 14 (5): 267-73.

47. Gürses M, Erdoğan A. Erzurum piyasasında satılan yerfıstığı, antepfıstığı ve bademlerin aflatoksin $B_{1}$ kontaminasyonu bakımından incelenmesi. Atatürk Üniv Ziraat Fak Derg, 2004; 35 (1-2): 75-8.

48. Gürses M. Mycoflora and aflatoxin content of hazelnuts, walnuts, peanuts, almonds and roasted chickpeas (leblebi) sold in Turkey. Int J Food Prop, 2006; 9: 395-9. 
49. Bircan C, Barringer SA, Ulken Ü, Pehlivan R. Aflatoxin levels in dried figs, nuts and paprika for export from Turkey. Int J Food Sci Tech, 2008; 43 (8): $1492-8$.

50. Aycicek H, Aksoy A, Saygi S. Determination of aflatoxin levels in some dairy and food products which consumed in Ankara, Turkey. Food Control, 2005; 16 (3): 263-6.

51. Oruç HH, Cengiz M, Kalkanli O. Comparison of aflatoxin and fumonisin levels in maize grown in Turkey and imported from the USA. Anim Feed Sci Tech, 2006; 128: 337-41.

52. Özay G, Alperden I. Aflatoxin and ochratoxin-a contamination of dried figs (Ficus carina L.) from the 1988 crop. Mycotoxin Res, 1991; 7: 85-91.

53. Giray B, Girgin G, Engin AB, Aydın S, Șahin G. Aflatoxin levels in wheat samples consumed in some regions of Turkey. Food Control, 2007; 18 (1): 23-9.

54. Aydın A, Erkan ME, Bașkaya R, Ciftcioğlu G. Determination of aflatoxin $\mathrm{B}_{1}$ levels in powdered red pepper. Food Control, 2007; 18 (9): 1015-8.

55. Yentür G. Bazı gıda maddelerinde aflatoksin $B_{1}$ ve $M_{1}$ düzeylerinin saptanması. Gazi Üniversitesi Bilimsel Araștırma Projesi. No: 02/2009-16, 2010.

56. Demirer MA, Dinçer B, Kaymaz Ş, Alperden I, Yalçın S, Özer E. Bazı gıda maddelerinde mikroflora ve mikotoksin araștırmaları. AÜ Vet. Fak. Derg, 1989; 36 (1): 85-107.

57. Var I, Kabak B, Gök F. Survey of aflatoxin $B_{1}$ in helva, a traditional Turkish food, by TLC. Food Control, 2007; 18 (1): 59-62.

58. Gürbay A, Aydın S, Girgin G, Engin AB, Şahin G. Assessment of aflatoxin $M_{1}$ levels in milk in Ankara, Turkey. Food Control, 2006; 17 (1): 1-4.

59. Sarımehmetoğlu B, Kuplulu O, Celik TH. Detection of aflatoxin $M_{1}$ in cheese samples by ELISA. Food Control, 2004; 15 (1): 45-9.
60. Gürses $M$, Erdoğan A, Çetin B. Occurrence of aflatoxin $M_{1}$ in some cheese types sold in Erzurum, Turkey. Turk J Vet Anim Sci, 2004; 28: 527-30.

61. Elmalı M, Yapar K, Kart A, Yaman H. Aflatoksin $M_{1}$ levels in milk powder consumed in Turkey. J Anim Vet Adv, 2008; 7 (5): 643-5.

62. Ardıç M, Karakaya Y, Atasever M, Adiguzel G. Aflatoxin $M_{1}$ levels of Turkish white brined cheese. Food Control, 2009; 20 (3): 196-9.

63. Anonim. Türk Gıda Kodeksi - 2008/26 No’lu Gıda Maddelerindeki Bulașanların Maksimum Limitleri Hakkında Tebliğ, 2008.

64. Park JW, Kim EK, Kim YB. Estimation of the daily exposure of Koreans to aflatoxin $B_{1}$ through food consumption. Food Addit Contam, 2004; 21 (1): 70-5.

65. Anonim. Türk Gıda Kodeksi - 2009/22 No’lu Gıda Maddelerindeki Bulașanların Maksimum Limitleri Hakkında Tebliğde Değișiklik Yapılması Hakkında Tebliğ, 2009.

66. Basaran P, Ozcan M. Occurrence of aflatoxins in various nuts commercialized in Turkey. J Food Safety, 2009; 29 (1): 95-105.

67. Pei SC, Zhang YY, Eremin SA, Lee WJ. Detection of aflatoxin $M_{1}$ in milk products from China by ELISA using monoclonal antibodies. Food Control, 2009; 20 (12): 1080-5.

68. Virdis S, Corgiolur G, Scarano C, Pilo AL, De Santis EPL. Occurrence of aflatoxin M1 in tank bulk goat milk and ripened goat cheese. Food Control, 2008; 19 (1): 44-9.

69. Torkar KG, Vengušt A. The presence of yeasts, moulds and aflatoxin $M_{1}$ in raw milk and cheese in Slovenia. Food Control, 2008; 19 (6): 570-7.

70. Saha D, Acharya D, Roy D, Shrestha D, Dhar TK. Simultaneous enzyme immunoassay for the screening of aflatoxin $B_{1}$ and ochratoxin $A$ in chili samples. Anal Chim Acta, 2007; 584 (2): 343-9. 


\title{
Gıdalarda aflatoksin varlığının değerlendirilmesi
}

\section{The evaluation of the aflatoxin levels present in food}

\author{
Gülderen YENTÜR ${ }^{1}, \quad$ Buket ER ${ }^{1}$
}

\section{ÖZET}

Aflatoksinler tahıllar, yağı tohumlar, baharatlar, etler, süt ve süt ürünlerini içeren pek çok gıda ile hayvan yemlerinde yaygın olarak bulunabilen mikotoksinlerdir. Gıdalar ve hayvan yemleri ürün ișleme, depolama ve satıș sırasında aflatoksinlerle kontamine olabilmektedir. Aflatoksin kontaminasyon düzeyleri iklimsel, bölgesel özellikler veya gıda çeșidine göre farklılıklar gösterebilmektedir. Aflatoksinler genellikle gidalarda ve yemlerde stabil ve sıcaklığa karșı dirençlidirler. Bu toksinlerin olușumu için gereken koșullar devam ettiğinde kontaminasyon oranı artabilmektedir. Kontamine olan gıdaların aflatoksinlerden tamamen arındırılması da pek mümkün görünmemektedir. Aflatoksin detoksifikasyonu yeterli olmadığı için kontaminasyonun kontrol altında tutulması gerekmektedir. Aflatoksin oluşumunun önlenmesi için üretimden tüketime kadar çeșitli șekillerde bulașan küflerin gelișiminin ileri teknolojiler ve iyi uygulamalarla engellenmesi gerekmektedir. Aflatoksinler insanlara kontamine gidalar ve kontamine yemlerle beslenen hayvanlardan elde edilen ürünler aracılığıyla ulașarak akut veya kronik toksisiteye neden olabilmektedir. Toksisite derecesini maruziyet düzeyi, yaș, cinsiyet, beslenme ve bazı sağlık faktörleri etkilemektedir. Aflatoksinler en toksik mikotoksinlerdir. Yapılan çalıșmalarda aflatoksinlerin toksik, kanserojenik, teratojenenik,

\section{ABSTRACT}

Aflatoxins are mycotoxins that are widely found in food products such as cereals, oil seeds, spices, meat, milk and milk products and also animal feeds. Food for humans and animals could be contaminated with aflatoxins during the product processing, storage and sale. Levels of aflatoxin contamination also may vary according to the climate, regional characteristics or type of food. Aflatoxins in food and feed are usually stable and resistant to heat. The contamination rate may increase when the conditions for the formation of these toxins continue existing. Apparently, it is not possible to completely purify contaminated food from aflatoxins or detoxify the aflatoxin. To prevent accumulation of aflatoxin, contamination of the food with molds should be prevented with developing technologies and best practices. Humans come in contact with aflatoxin through contaminated food and animal products. As a result, aflatoxin can cause acute or chronic toxicitiy, while the quantity of aflatoxin injested, the age, sex, and health factors might affect the degree of toxicity. Aflatoxins are one of the most toxic mycotoxins. In previous studies it was shown that aflatoxins could be dangerous for human

\section{Gazi Üniversitesi, Eczacılık Fakültesi, Besin Analizleri Bilim Dalı, 06330, Etiler, ANKARA}

İletişim/Corresponding Author : Gülderen YENTÜR

Gazi Üniversitesi, Eczacilık Fakültesi, Besin Analizleri Bilim Dalı, 06330, Etiler, ANKARA

Tel : +903122023200
Geliş Tarihi / Received : 28.07.2011 Kabul Tarihi / Accepted : 16.11.2011

DOI ID : 10.5505/TurkHijyen.2012.54154

Yentür G, Er B. Gıdalarda aflatoksin varlığının değerlendirilmesi. Turk Hij Den Biyol Derg, 2012; 69(1): 41-52. 
hepatotoksik ve mutajenik karekteristiği nedeniyle insan hayatı için tehlikeli olabileceği belirtilmiștir. Bu nedenle aflatoksin kontaminasyonu gıda güvenliği açısından önemini korumaktadır. Yüksek miktarlarda aflatoksin içeren gıdaların uzun süre tüketimi halk sağlığı açısından problem yaratabileceği gibi aynı zamanda ihracatı da olumsuz yönde etkileyerek ülkede ekonomik kayıplara neden olabilecektir. Diğer birçok ülkede olduğu gibi Türkiye'de pek çok gıda maddesi için Aflatoksin $B_{1}\left(A_{F} B_{1}\right)$, Toplam Aflatoksin-TAF $\left(B_{1}, B_{2}, G_{1}\right.$ ve $\left.G_{2}\right)$ ve Aflatoksin $M_{1}$ $\left(A F M_{1}\right)$ ile ilgili yasal sınırlar belirlenmiștir. Bu derlemede, kanserojenik, teratojenenik, hepatotoksik ve mutajenik etkileri ile ön plana çıkan aflatoksinlerin gıdalardaki varlığı ve son yıllardaki kontaminasyon durumunun değerlendirilmesi amaçlanmıștır.

Anahtar Sözcükler: Aflatoksin, gıda, karsinojen, kontaminasyon, detoksifikasyon due to their toxic, carcinogenic, teratogenic, hepatoxic and mutagenic characteristic. Therefore, aflatoxins contamination remains of importance in terms of food safety. Long-term consumption of food containing high amounts of aflatoxin may result in health problems and adversely affect the export of several products and cause economic losses. In Turkey, similarly to other countries Aflatoxin $B_{1}\left(A F B_{1}\right)$, Total Aflatoxin-TAF $\left(B_{1}, B_{2}, G_{1}\right.$ and $\left.G_{2}\right)$ and Aflatoxin $M_{1} \quad\left(A F M_{1}\right)$ levels in food should be kept within the legal limits. The present review aimed to evaluate the emerging role of aflatoxin as carcinogenic, teratogenic, hepatoxic and mutagenic products present in food.

Key Words: Aflatoxin, food, carcinogen, contamination, detoxification

\section{GíRiş}

Mikotoksinler tarım ürünlerinde tarladan tüketime kadar olan aşamalarda, ekolojik koșullara bağlı olarak gelișen ve üreyen bazı alt-mantarların sekonder metabolitleridir. Bu toksinler belirli nem ve sıcaklık koșullarında Aspergillus, Penicillium ve Fusarium gibi bazı küfler tarafından olușturulurlar $(1,2)$. En sık karșılașılan mikotoksinler aflatoksin (AF), okratoksin, trikotesen, zeranol, patulin, siklopiazonik asit, nivalenol ve fumonisin olarak siralanabilir $(2,3)$. Bilinen 400 mikotoksin arasında aflatoksinler insan sağlığı açısından en tehlikeli olanlardır (3). Mikotoksinler içerisinde önemli yere sahip bu toksinler, İngiltere'de çok sayıda kanatı hayvanın ölümü ile sonuçlanan “Turkey $X$ ” hastalığı sonucunda keșfedilmişlerdir. Yüz binden fazla hindi ve diğer çiftlik hayvanının ölümüyle sonuçlanan hindi hastalığı salgınları sonrasında aflatoksinler heterosiklik bileșikler ile bağlantılı bir grup olarak 1960 yılında bulunmuștur (4,5). Aflatoksinler, Aspergillus flavus, Aspergillus parasiticus ve Aspergillus nomius küfleri

tarafından üretilen toksik metabolitlerdir (1). A. parasiticus $\mathrm{AFB}_{1}, \mathrm{AFB}_{2}, \mathrm{AFG}_{1}$ ve $\mathrm{AFG}_{2}$ aflatoksinlerinin hepsini üretirken $A$. flavus nadiren $A F G_{1}$ ve $A F G_{2}$ üretmektedir (6).

Aflatoksinle kontamine yemlerin tüketimi hayvan sağlığını ve üretimini olumsuz etkilemektedir. Aynı zamanda bu hayvanların et, yumurta ve sütlerinin tüketimi de insan sağlığı açısından tehlike olușturmaktadır (7). Bu toksinler akut ölümlerden kronik hastalıklara kadar geniş aralıklarda etki gösterebilirler (8). Genellikle eser miktarlarda (izin verilen kalıntı düzeylerinin biraz üzerinde) bile etkili, uçuculuğu az, teknolojik ișlemlere ve sıcaklığa karșı dirençlidirler (9). Bu nedenle de pek çok ülkede gıdaların ve yemlerin mikotoksin ile kontaminasyonu belirli analiz programları ile izlenmektedir. Bu derlemede, kanserojenik, teratojenenik, hepatotoksik ve mutajenik etkileri ile ön plana çıkan aflatoksinlerin gıdalardaki varıı̆ı ve son yıllardaki kontaminasyon durumunun değerlendirilmesi amaçlanmıștır. 


\section{GIDALARINAFLATOKSINLERLE KONTAMINASYONU}

Çiftlik hayvanlarının beslenmesinde yararlanılan yemler yanında insanların beslenmesinde önemli bir yere sahip olan gida maddelerinin aflatoksin ile kontaminasyonu dünyanın çeșitli bölgelerinde sık karșılașılan bir durumdur. Dolayısıyla bu kontaminasyonlar hem gıda güvenliğini etkileyerek halk sağlığı açısından risk olușturmakta hem de tarım endüstrisinde önemli ekonomik kayıplara neden olmaktadır (3).

Aflatoksinler hasat, kurutma, depolama, gida ve yem halinde ürünü ișleme aşamasında oluşabildiği gibi ürün tarlada veya bahçede gelișirken de meydana gelebilmektedir. Aflatoksin oluşumunu ürün nemi, kurutma hızı, ortamın nisbi nemi, sıcaklık, ortamda bulunan fungus veya sporlarının yoğunluğu, gelișen türlerin toksin olușturma güçleri, mikroorganizmalar arası rekabet, ürünün ve yetiștirilen çeșidin direnci, böcek veya diğer zararlıların faaliyeti, bitki stresi, hava sıcaklığı, atmosferik gazların bileșimi gibi birçok etken etkilemektedir (10).

Aflatoksinlerin gelișmesinde nisbi nem ve sıcaklık önemli parametrelerdir. Aflatoksin gelișmesi için optimum şartlar $24-35{ }^{\circ} \mathrm{C}$ ve \%70'in üzerindeki nisbi nemdir $(11,12)$. Ayrica gidalarda aflatoksin üretimi ve misel gelişimi sıcaklık ve su aktivitesi (aw) ile kontrol edilmektedir. Diğer faktörler ise sıcaklık uygulaması, modifiye atmosfer paketleme ve koruyucu madde kullanımıdır (13). Bu nedenle hava veya günește kuruyan tahıl, pamuk, yerfıstığı ve fındık gibi tohumlarda yaygın bir kontaminanttır (14). Mısır da yetiștirme, hasat, depolama, tașıma ve işlem basamaklarında genellikle mikotoksine maruz kalan gidalardandır. Hasat öncesi ve sonrasında A. flavus ile enfekte olan misırlarda kurutma ve depolama koşullarının iyi olmaması halinde aflatoksin kontaminasyonunda artış görülmektedir (15).

Küf gelişimi için gerekli olan sıcaklık ve su aktivitesi (aw) değerleri toksin oluşumu için gereksinim duyulan değerler ile aynı olmamakta ve türe göre de değișiklik göstermektedir. Örneğin A. parasiticus 0,82 aw'de gelișip 0,83 aw'de toksin üretmektedir. A. flavus'un gelișmesi ve mikotoksin üretiminde ise aw sırasıyla 0,73 ve 0,85 'dir. Bu durumda nem içeriği de $\% 8-12$ ve \%17-19'dir (15).

Küf ve toksin oluşumu için gerekli minimum sıcaklık değerleri de farklıık göstermektedir. A. parasiticus'un gelişmesi için en düşük sıcaklık aralığ $16-8{ }^{\circ} \mathrm{C}$ iken 25$35{ }^{\circ} \mathrm{C}$ 'de optimum gelișme sağlanmaktadır. A. flavus için ise en iyi gelişme aralığ $19-35{ }^{\circ} \mathrm{C}$ iken $12-42{ }^{\circ} \mathrm{C}$ arasında toksin üretmektedir (16).

Aflatoksin kontaminasyonu hizlıca oluşabilmektedir. Yapılan bir çalıșmada, A. flavus inokule edilen bitkilerde iki gün sonra 0,3-2 ppb, dört gün sonra 950-2.800 ppb ve yedi gün sonra ise 3.600-4.500 ppb miktarlarında aflatoksin varlığına rastlandığı belirtilmiștir (17).

\section{GIDALARINAFLATOKSINLERLE DEKONTAMINASYONU VEYA AFLATOKSINLERIN DETOKSIFIKASYONU}

Aflatoksinler difuranokumarin yapısına sahip bileșiklerdir ve iki kimyasal grubu vardır. Bunlar $A F B_{1}, A F B_{2}, A F B_{2} A, A F M_{1}, A F M_{2}, A F M_{2} A$ ve aflatoksikol içeren difurokumarosiklopentanon serisi ile $A F G$, ve $A F G_{2}$ ' $i$ içeren difurakumarolakton serisidir (17). Yirmi aflatoksin türü tanımlanmasına rağmen bunlardan $A \mathrm{FB}_{1}, \mathrm{AFB}_{2}, A F \mathrm{~F}_{1}$ ve $A \mathrm{FG}_{2}$ belli başlılarıdır. Bunlar kromatogramdaki hareketleri ve floresans özelliklerine göre adlandırılmaktadırlar (18). Ultraviyole ıșık altında mavi floresans verenler $\mathrm{AFB}_{1}$ ve $A F B_{2}$, yeșil floresans verenler ise $A F G_{1}$ ve $A F G_{2}$ olarak adlandırılmaktadır (19). $\mathrm{AFB}_{1}$ ve $\mathrm{AFB}_{2}$ içeren yemlerle beslenen ineklerin sütünde rastlanan, ana moleküle benzer fakat daha az biyolojik etki gösteren türevler ise $A F M_{1}$ ve $A F M_{2}$ olarak adlandırılmaktadır (20).

$A F B_{1}$ molekülünün fizikokimyasal ve biyokimyasal özellikleri incelendiğinde toksikolojik affinitesinde iki önemli bölge vardır. İlk bölgede furofuran halkası c-8, 9 pozisyonunda çift bağlanmıștır ve aflatoksin DNA ve protein etkileșimlerinden olușmaktadır. ikinci reaktif grup ise kumarin fonksiyonel grubuna bağlı lakton halkasıdır. Bu halka kolay hidrolize olur. 
Bu yüzden de degradasyon için zayıf bölgedir (21).

Aflatoksinlerin yapısal degradasyonu veya inaktivasyonu kimyasallarla mümkündür. Özellikle de sodyum hipoklorit, klorindioksit, klorin gazı, hidrolitik ajanlardan organik ve inorganik asitler ve sodyum hidroksit, amonyum hidroksit ve potasyum hidroksit gibi alkaliler ile degradasyon sağlanabilmektedir (22). Bu kimyasalların bir kısmı gıda endüstrisinde kullanılmasına rağmen çoğu toksik kalıntı bıraktığından, besin içeriğine zarar verdiğinden, tat, koku, renk, tekstür ve ürünün fonksiyonel özelliklerini etkilediğinden kullanılmaları uygun değildir (21). İnsan gıdalarının ve hayvan yemlerinin kontaminasyonunun fiziksel, kimyasal ve biyolojik metotlarla kontrolü ile ilgili birçok çalıșma mevcuttur. Bunlar toksini daha az mutajenik etkili ve daha az zararlı hale dönüștürmek içindir. Bu kimyasallar asitler, oksitleyici ajanlar, bisülfitler ve gazlardır (23). Mikrodalga ile ısıtma, ozon ile muamele (ozonlama) veya amonyak gibi birçok fiziksel ve kimyasal yöntemler aflatoksin ile kontamine olmuș gıdaların detoksifikasyonu için tavsiye edilmektedir. Son zamanlarda gıdalarda aflatoksin detoksifikasyonu için bir oksidasyon yöntemi olan ozonlama geliștirilmiștir. Ozon veya triatomik oksijen $\left(\mathrm{O}_{3}\right)$, güçlü bir dezenfektan ve oksitleyici ajandır (24).

Mikotoksinler, radyasyon dozuna bağlı olarak gıda ve mikotoksinin tipine göre gama $(\gamma)$ ışınları radyasyonu ile inaktive olabilmektedirler. Bununla birlikte $\gamma$-radyasyon ile aflatoksinlerin bozunmasında su aktivitesi kritik rol oynamaktadır. Rustom (4) yaptığı çalıșmada, 1 ve 10 kGy dozunda $\gamma$-ıșını uygulanan yerfıstığı örneklerinde sırasıyla \%75 ve \%100 azalma görüldüğünü belirtmiștir. Aflatoksinler 222, 265 ve 362 nm'de UV radyasyonuna duyarlıdırlar. En büyük absorpsiyonu ise 362 nm'de göstermektedir. $1 \mathrm{ppb} \mathrm{AFM}_{1}$ ile kontamine süt örneklerine 20 dakika $365 \mathrm{~nm}$ radyasyon uygulandığında \%56,2'sinin yıkımlandığı bildirilmiștir (4,25,26). Mikroorganizmalarla aflatoksin detoksifikasyonuna ilișkin çalıșmalarda bulunmaktadır. Thanaboripat ve ark., (27) yaptıkları çalıșmada, ticari olarak üretilen yoğurtlarda laktik asit bakterileri ve Streptococcus lactisileaflatoksinin detoksifikasyonunu araștırmıșlardır. Sonuç olarak da, S. lactis ile $\mathrm{AFB}_{1}$ düzeyinin 50'den $33,70 \mu \mathrm{g} \mathrm{ml}^{-1}$ 'ye düștüğünü ve laktik asit bakterilerine göre detoksifikasyon için daha yetenekli olduklarını belirtmișlerdir.

Dekontaminasyon veya detoksifikasyon ișlemi mikotoksin ile kontamine olan besin maddeleri açısından yararlıdır. İdeal dekontaminasyon işlemi ucuz ve uygulaması kolay olmalı, toksik metabolit oluşumuna yol açmamalıdır. Yemlerin besinsel ve tat özelliklerini değiștirebilecek ve yeni mikotoksin oluşumuna yol açabilecek özellikte olmamalıdır. Bu nedenle mikotoksin kontaminasyonunun önlenmesi daha önemlidir $(21,28)$.

\section{AFLATOKSINLERIN VÜCUDA ALINMASI VE ETKILERi}

Mikotoksinler insanlara kontamine besinler ve kontamine yemlerle beslenen hayvanlardan elde edilen ürünler aracılığıyla kalıntı düzeylerinde de olsa ulașırlar (9). Az gelișmiș veya gelișmekte olan ülkelerde besinlerin yaklașık \%25'inin mikotoksinlerle ve metabolitleriyle kontamine olduğu görülmektedir. Mikotoksinler genellikle kontamine gıdanın tüketilmesi ile vücuda alınıyor olsa da toksijenik sporların inhalasyonu ve doğrudan deri ile temas diğer maruziyet yollarıdır (29). Dünyanın değișik yerlerinde insanların günlük aflatoksin alım miktarları 0-30.000 $\mathrm{ng} \mathrm{kg}^{-1}$ arasında değișmektedir (19).

İnsanlar diyet ile düșük miktarda toksine maruz kalabilmektedir. Uzun vadede düșük dozda aflatoksine maruz kalınması çok tehlikeli sonuçlara neden olabilmektedir $(30,31)$. Aflatoksine maruziyet durumu, kișinin yașı, beslenme düzeni, hepatit $B$ enfeksiyonu gibi bazı sağlık faktörleri aflatoksinlerin toksisite derecesini etkilemektedir (32).

Aflatoksinlerin insan ve hayvanlarda olușturduğu akut ve kronik seyirli mikotoksikoza aflatoksikoz 
adı verilmektedir (32). Ayrıca aflatoksinlerin siroz, hepatit, kronik gastrit, Reye sendromu ve böbrek hastalıklarına neden olabildiği belirtilmektedir (33). Bununla birlikte, aflatoksinlerin çocuklarda Kwashiorkor hastalığı ile bağlantılı olduğu da bildirilmektedir (4). Aflatoksin insan kordon kanında bulunmuștur ve bu durumda gelișmekte olan fetüse de geçebilmektedir (19). Ayrıca mikotoksinler hayvanlarda verim kaybı, ağırlık artışında azalma, immunosupresyon ve kanser olușumuna neden olabilmektedirler. Bulașmıș yemlerle beslenen hayvanlarda zehirlenmeler oluşabilmektedir (31).

Aflatoksinler olușturdukları toksik etki gücüne göre $A F B_{1}>A F G_{1}>A F B_{2}>A F G_{2}$ șeklinde sıralanmaktadır (17). $\mathrm{Bu}$ toksinler içerisinde $\mathrm{AFB}_{1}$ 'in insan sağlığı açısından en toksik ve en yaygın olduğu belirtilmektedir $(33,34)$. Aflatoksinler akut ve kronik toksisiteye ve büyük bir bölümü ise karsinojenik, mutajenik ve teratojenik etkiye sahiptirler (35). Uluslararası Kanser Araștırma Kurulușu (International Agency of Research on CancerIARC) tarafından AFB ${ }_{1}$ Grup 1 karsinojen, AFM ise Grup 2 karsinojen olarak bildirilmiștir (36). AFB ${ }_{1}$ in toksik ve karsinojenik etkileri için temelde hedef organlar karaciğer ve böbrektir. Aflatoksinin hepatotoksik, hepatokarsinojenik ve teratojenik etkileri farkl hayvan türlerinde gösterilmiștir (37). AFB 1 rat, fare, maymun, marmoset, ördek, lepistes, somon, alabalık ve kır faresi gibi bazı hayvanlarda malignant tümör oluşumunu indükleyebilmektedir. Bu bileșikler için hedef organ karaciğer olmakla beraber bazı ratlarda böbrek ve intestinal tümörler görülebilmektedir (38). Bununla birlikte hepatokarsinoma gelișiminde aflatoksinlerin etkili olabileceği belirtilmektedir $(39,40)$. Türkiye'de yapılan bir çalıșmada viral hepatit hastalarında sağlıklı bireylere göre aflatoksin maruziyetinin yüksek olduğu ve bu durumun hepatosellüler karsinoma gelișiminde önemli bir rol oynayabileceği belirtilmiștir (41). Mikotoksin zehirlenmelerinde etkin bir tedavi yöntemi yoktur. Kontamine olan besinlerin mikotoksinlerden arındırılması da olası görünmemektedir. Bu nedenle, insan sağlığı bakımından kontamine gıdaların tüketiminden kaçınılması ve gıdaların kontaminasyonuna karșı etkin önlemlerin alınması önemlidir (9).

\section{GIDALARDA AFLATOKSIN VARLIĞI VE YASAL DÜZENLEMELER}

Aflatoksinler dünyada çiğ olarak tüketilen gıdalardan özellikle yerfıstığı, fındık, kakao, kahve, mısır, pirinç, pamuk, buğday ve diğer tahıl ürünleri ile kuru meyvelerde yaygın șekilde olușmaktadır $(20,42,43)$. Aynı zamanda süt ve süt ürünleri, etler, kırmızı biber ve kırmızı biber ürünleri gibi baharatlar da dahil olmak üzere pek çok gıdada yaygın olarak bulunabilmektedir $(42,44,45)$. Yüksek miktarlarda aflatoksin içeren gıdaların uzun süre tüketimi halk sağlığı açısından problem yaratabileceği gibi aynı zamanda ihracatı da olumsuz yönde etkileyebileceğinden ülkede ekonomik kayıplara neden olabilmektedir. Bu yüzden mikotoksinlerin gelișiminin üretimden tüketime kadar izlenebilirliği önem tașımaktadır $(21,43)$. Yapılan araștırmalar sonucunda; Türkiye'de tüketime sunulan bazı gıda maddelerine ait belirlenen aflatoksin düzeyleri Tablo 1'de sunulmuștur (31, 42-62). Bu değerler incelendiğinde; gıda çeșidi, bölgesel ve mevsimsel özellikler gibi faktörlerin etkisiyle farklılıkların bulunduğu görülmüștür.

Türkiye' de diğer birçokülkede olduğu gibi gıdalarda aflatoksin kontaminasyonu ile ilgili yasal kısıtlamalar vardır. Avrupa Birliğine uyum süreci çerçevesinde hazırlanan 2008/26 sayılı gıda maddelerindeki bulașanların maksimum limitleri hakkındaki Türk Gıda Kodeksi (TGK) Tebliğinde pek çok gıda maddesi için $A F B_{1}$, toplam Aflatoksin-TAF $\left(B_{1}, B_{2}, G_{1}\right.$ ve $\left.G_{2}\right)$ ve $A F M_{1}$ ile ilgili sınırlar belirtilmiștir (63).

Asya ülkelerinin birçoğunda pirinç aflatoksin sıklığı ve kontaminasyonunda temel gıdadır. Ayrıca arpa ve mısır bazlı gıdalarda da aflatoksin varlığı bildirilmiştir (64). Özellikle tohumlarda yüksek miktarlarda aflatoksin olduğu bilinmektedir. 
Tablo 1. Türkiye'de tüketime sunulan bazı gıda maddelerine ait aflatoksin düzeyleri

\begin{tabular}{|c|c|c|c|c|}
\hline Örnek & Örnek Miktarı & Aflatoksin Türü & Aflatoksin Düzeyleri & Kaynak \\
\hline \multirow{5}{*}{ Yerfıstığı ve ürünleri } & 85 & $\mathrm{AFB}_{1}$ & $0-21 \mathrm{ppb}$ & Özay ve Alperden (46) \\
\hline & 5 & $\mathrm{AFB}_{1}$ & 1,2-11,3ppb & Gürses ve Erdoğan (47) \\
\hline & 7 & $\mathrm{AFB}_{1}$ & 8-94 ppb & Gürses (48) \\
\hline & 20 & TAF & $8,16-75,74 \mathrm{ng} \mathrm{kg}^{-1}$ & Yentür ve ark. (43) \\
\hline & 5 & TAF & $0,75-26,36 \mu \mathrm{g} \mathrm{kg}^{-1}$ & Bircan ve ark. (49) \\
\hline \multirow{3}{*}{ Fındık ve ürünleri } & 81 & $\mathrm{AFB}_{1}$ & $<1-13 \mathrm{ppb}$ & Ayçiçek ve ark. (50) \\
\hline & 9 & $\mathrm{AFB}_{1}$ & $1-113 \mathrm{ppb}$ & Gürses (48) \\
\hline & 2 & TAF & $5,46-6,55 \mu \mathrm{g} \mathrm{kg}^{-1}$ & Bircan ve ark. (49) \\
\hline Badem & 9 & $\mathrm{AFB}_{1}$ & $2,9-4,7 \mathrm{ppb}$ & Gürses ve Erdoğan (47) \\
\hline Badem & 3 & $\mathrm{AFB}_{1}$ & $1-3 \mathrm{ppb}$ & Gürses (48) \\
\hline Ceviz & 6 & $\mathrm{AFB}_{1}$ & 3-28ppb & Gürses (48) \\
\hline Misir & 26 & TAF & $0,01-32,30 \mu \mathrm{g} \mathrm{kg}^{-1}$ & Oruç ve ark. (51) \\
\hline İncir & 103 & $\mathrm{AFB}_{1}$ & $0,5-63,0 \mu \mathrm{g} \mathrm{kg}^{-1}$ & Özay ve Alperden (52) \\
\hline Leblebi & 1 & $\mathrm{AFB}_{1}$ & $1-2 \mathrm{ppb}$ & Gürses (48) \\
\hline Baharat & 36 & TAF & $0,3-46,8 \mu \mathrm{g} \mathrm{kg}^{-1}$ & Çolak ve ark. (42) \\
\hline Buğday & 24 & TAF & $10,4-643,5 \mathrm{ng} / \mathrm{kg}$ & Giray ve ark. (53) \\
\hline Buğday unu & 50 & TAF & $<1,75-<4 \mathrm{ppb}$ & Özturan ve ark. (31) \\
\hline \multirow{2}{*}{ Fistık } & 3 & $\mathrm{AFB}_{1}$ & $1,1-1,5 \mathrm{ppb}$ & Gürses ve Erdoğan (47) \\
\hline & 16 & TAF & $2,31-63,11 \mu \mathrm{g} \mathrm{kg}^{-1}$ & Bircan ve ark. (49) \\
\hline \multirow{4}{*}{ Kırmızıbiber ve ürünleri } & 100 & $\mathrm{AFB}_{1}$ & $<0,025-40,9 \mu \mathrm{g} \mathrm{kg}^{-1}$ & Aydın ve ark. (54) \\
\hline & 72 & TAF & $0,11-24,7 \mu \mathrm{g} \mathrm{kg}^{-1}$ & Ardıç ve ark. (44) \\
\hline & 19 & TAF & $1,79-6,55 \mu \mathrm{g} \mathrm{kg}^{-1}$ & Bircan ve ark. (49) \\
\hline & 190 & $\mathrm{AFB}_{1}$ & $0,20-6,12 \mathrm{ppb}$ & Yentür (55) \\
\hline \multirow{2}{*}{ Susam } & 2 & TAF & - & Demirer ve ark. (56) \\
\hline & 20 & $\mathrm{AFG}_{1}$ & $0,06-2,04 \mathrm{ng} \mathrm{kg}^{-1}$ & Yentür ve ark. (43) \\
\hline Helva & 102 & $\mathrm{AFB}_{1}$ & $<1-18 \mu \mathrm{g} \mathrm{kg}^{-1}$ & Var ve ark. (57) \\
\hline \multirow[t]{2}{*}{ Süt } & 27 & $\mathrm{AFM}_{1}$ & $<10-50,5 \mathrm{ng} \mathrm{L}^{-1}$ & Gürbay ve ark. (58) \\
\hline & 220 & $\mathrm{AFM}_{1}$ & $0-0,26 \mathrm{ppb}$ & Er ve ark. (45) \\
\hline \multirow{5}{*}{ Süt Ürünleri } & 400 & $\mathrm{AFM}_{1}$ & $<50->800 \mathrm{ng} \mathrm{kg}^{-1}$ & Sarımehmetoğlu ve ark. (59) \\
\hline & 28 & $\mathrm{AFM}_{1}$ & $7-202 \mathrm{ng} \mathrm{kg}^{-1}$ & Gürses ve ark. (60) \\
\hline & 80 & $\mathrm{AFM}_{1}$ & $<1->601 \mathrm{ng} \mathrm{kg}^{-1}$ & Elmalı ve ark. (61) \\
\hline & 193 & $\mathrm{AFM}_{1}$ & $<50-860 \mathrm{ng} \mathrm{kg}^{-1}$ & Ardiç ve ark. (62) \\
\hline & 70 & $\mathrm{AFM}_{1}$ & $0-0,24 \mathrm{ppb}$ & Er ve ark. (45) \\
\hline
\end{tabular}


Yerfıstığının depolanmasında nem \%8'in ve ortam sıcaklığı $25{ }^{\circ} \mathrm{C}$ 'nin üzerinde ise aflatoksin olușturan küfler meydana gelmektedir (17). Türk Gıda Kodeksi Tebliğinde, doğrudan tüketime sunulmadan veya gıda bileșeni olarak kullanılmadan önce sınıflandırma, ayıklama gibi fiziksel ișlemlere tabi tutulan mısır ve yerfıstıklarında maksimum $A_{F B}$ ve toplam aflatoksin miktarlarının sırasıyla 8 ve $15 \mu \mathrm{gg}^{-1}$ olabileceği belirtilmiștir. Aynı Tebliğde tahıllar (karabuğday Fagopyrum sp. dahil) ve bunlardan üretilen işlenmiş gidaların maksimum $\mathrm{AFB}_{1}$ ve toplam aflatoksin miktarları sırasıyla 2 ve $4 \mu \mathrm{gg}^{-1}$ olarak bildirilmiștir. Ayrıca fındık, antepfıstığı gibi sert kabuklu meyveler, yer fıstığı, yağlı tohumlar, kuru meyveler ve bunlardan üretilen işlenmiş gıdalar için maksimum toplam aflatoksin miktarı da $10,0 \mu \mathrm{g} \mathrm{kg}^{-1}$ olarak belirtilmiștir $(63,65)$.

Başaran ve Özcan (66) yaptıkları çalışmada 217 kuruyemiş örneğinde $A F B_{1}, A F B_{2}, A F G_{1}$ ve $A F G_{2}$ miktarlarını araștırmışlardır. Örneklerin \%14,28'inde düşük miktarlarda ve \%1,84'ünde de sınır değerlerinin üstünde aflatoksin saptamıșlardır.

Bircan ve ark., (49) yaptıkları çalıșmada 2.643 kuru yemiş örneğinin 313 tanesinde, 80 adet fındığın ikisinde, 28 fıstığın 16 'sında ve 10 yerfıstığının beșinde ve 23 biberin 19'unda sirasiyla 0,2-162,76; $5,46-6,55 ; 2,31-63,11 ; 0,75-26,36$ ve $1,79-6,55 \mu \mathrm{gg}^{-1}$ oranlarında toplam aflatoksin saptamıșlardır.

Süt ve süt ürünleri insanlar özellikle de çocuklar için hayvansal protein, kalsiyum, vitamin ve esansiyel yağ asidi gibi besin maddeleri için iyi bir kaynaktır $(34,67)$. Fakat süt ve süt ürünleri aynı zamanda aflatoksinler açısından da potansiyel kaynaktırlar (67). $A F{ }_{1}{ }_{1}$ in alınmasından 12-24 saat sonrasında sütte $A_{F M}$ saptanabilmektedir. Süt bazlı diğer ürünlerde de AFM, ürün ișlenme basamaklarından etkilenmemektedir (58). Bununla birlikte, $\mathrm{AFM}_{1}$ süte uygulanan pastörizasyon işlemine dayanıklıdır (67). Süt ve süt ürünleri açısından getirilen yasal kısıtlamalarda; çiğ süt, ısıl işlem görmüșs süt ve süt bazlı ürünlerin üretiminde kullanılan sütlerde maksimum $A F M_{1}$ miktarının $0,05 \mu \mathrm{g} \mathrm{kg}{ }^{-1}$ olması gerektiği belirtilmiștir (63).

Bebek ve küçük çocuk ek gıdaları için ise maksimum $\mathrm{AFB}_{1}$ miktarı 0,10 $\mu \mathrm{g} \mathrm{kg-1}$ olarak belirtilmiștir. Ayrıca, bebek mamalarında (bebek sütleri ve devam sütleri dahil) maksimum $\mathrm{AFM}_{1} \quad 0,025 \mu \mathrm{g} \mathrm{kg}^{-1}$, bebeklerin özel tıbbi amaçlı diyet gıdalarında maksimum $\mathrm{AFB}_{1}$ ve $A F M_{1}$ sirasiyla $0,10 \mu \mathrm{kg}^{-1}$ ve $0,025 \mu \mathrm{kg}^{-1}$ olarak bildirilmektedir. Aflatoksin bulunması muhtemel riskli gıdalar için ise genel olarak maksimum değerler $A F B_{1}$, toplam aflatoksin ve $A F M_{1}$ için sırasıyla $5,0,10,0$ ve $0,5 \mu \mathrm{g} \mathrm{kg}{ }^{-1}$ olarak belirtilmiştir (63). Virdis ve ark., (68) İtalya'da keçi sütü ve keçi sütünden yapılan peynirlerde $A F M_{1}$ kontaminasyonunu araștırmışlardır. 41 peynir örneğinin 4 (\% 9,8)'ünde AFM $_{1}$ ' i 79, 5-389 $\mathrm{ng} \mathrm{kg}^{-1}$ seviyeleri arasında bulduklarını belirtmişlerdir.

Torkar ve Vengust (69) Slovenya'da yaptıkları çalışmada çiğ süt ve peynir örneklerinde maya, küf ve $A F M_{1}$ varlığını araștırmışlardır. Peynir örneklerinin 4 (\% 10)' ünde $A F M_{1}$ seviyesinin $51-223 \mathrm{ng} \mathrm{kg}^{-1}$ arasında olduğunu belirtmişlerdir.

Bununla birlikte biber, zerdeçal, karabiber, kișniş ve kuru zencefil gibi baharatlarda hasat öncesi, hasat sonrası, depolama ve taşıma sırasında kontamine olabilmektedir (3). Türk Gıda Kodeksi Tebliğinde baharatlardan kırmızıbiber (Capsicum spp.), karabiber (Piper spp.), hintcevizi/muskat (Myristica fragrans), zencefil (Zingiber officinale), zerdeçal (Curcuma longa) gibi ürünlerde maksimum $\mathrm{AFB}_{1}$ ve toplam aflatoksin miktarları sirasiyla 5,0 ve 10,0 $\mu \mathrm{g} \mathrm{kg}{ }^{-1}$ olarak belirtilmiștir (63). Tüketimi çok olan gıdalardan biri de kırmızıbiber (Capsicum annuum) ve ürünleridir. Kırmızıbiber dünyada tüketimi yaygın olan çok popüler bir baharattır (70). Türkiye de Hindistan, Meksika, Amerika, İspanya gibi yüksek miktarda kırmızıbiber üreten ülkelerden birisidir. Kırmızı toz biberler Türkiye'de yemeklerin rengi, lezzeti ve aroması için çok sık kullanılan baharat çeșitleridir (54). Kırmızıbiber; üretim, hasat, kurutma ve daha sonraki ișleme safhalarında 
karșı karșıya kaldığı șartlar nedeniyle aflatoksin olușumuna hassas ürünlerden birisidir (62). Kırmızıbiber en yüksek oranda aflatoksin içeren baharat türüdür (71). Bu biberlerin mikotoksinler ile kontaminasyonunda bölgenin iklimi, ürün genotipi ve toprak tipi gibi birçok faktör etkilidir (72).

Dünyadaki en fazla biber üreticisi olan ülkeler tropik bölgelerde bulunmaktadır. Dolayısıyla kırmızıbiber ve ürünlerinde mikotoksin üreten küflerin gelișimi için uygun iklim koșulları bulunmaktadır (71). Bununla beraber biberler genellikle yetersiz hijyenik koșullar altında açık havada kurutulmaktadır (62). Kırmızıbiberler de diğer pek çok ürün gibi aflatoksinler ile hasat öncesinde, hasat sonrasında, depolama sırasında ve tașıma esnasında kontamine olabilmektedir (71,72). Gida maddelerindeki bulașanların maksimum limitleri hakkındaki 2008/26 sayılı Türk Gıda Kodeksi Tebliğinde, tüm ve toz kırmızıbiberler için maksimum $\mathrm{AFB}_{1}$ ve total aflatoksin miktarının sırasıyla $5 \mu \mathrm{g} \mathrm{kg-1}$ ve $10 \mu \mathrm{g} \mathrm{kg}^{-1}$ olduğu belirtilmiștir (63). Türk Gıda Kodeksi Tebliği, 1881/2006/EC sayılı gıda maddelerindeki belirli bulașanların maksimum miktarlarının belirlenmesi hakkında komisyon tüzüğü dikkate alınarak Avrupa Birliği'ne uyum süreci çerçevesinde hazırlanmıștır. Bu direktif 2010 yılında çıkan 165/2010 direktifi ile yeniden düzenlenmiștir $(73,74)$.

\section{KAYNAKLAR}

1. Zinedine A, González-Osnaya L, Soriano JM, Moltó JC, Idrissi L, Mañes J. Presence of aflatoxin M1 in pasteurized milk from Morocco. Int J Food Microbiol, 2007; 114 (1): 25-9.

2. Kumar V, Basu MS, Rajendran TP. Mycotoxin research and mycoflora in some commercially important agricultural commodities. Crop Prot, 2008; 27 (6): 891-905.

\section{SONUÇ}

Gida maddelerinin ve hayvan yemlerinin aflatoksinler ile kontaminasyonu dünya genelinde ciddi bir problemdir. Aflatoksinlerle kontamine olmuş gıdayı tüketen insanlarda ölümle sonuçlanabilen hastalıklar meydana gelebilmektedir. Farklı ülkelerde, çeșitli gıdalarda aflatoksin varlığının araștırıldığı çalıșmalar yapılmıștır. Bu araștırmalardaki aflatoksin düzeyleri iklimsel ve bölgesel nedenlerle veya gıda çeșidine göre farklılıklar gösterebilmektedir. Ayrıca mikrobiyolojik ve kimyasal detoksifikasyonla ilgili çalıșmalar incelendiğinde ise bazılarında aflatoksin düzeylerinde belli miktarda azalma görülmektedir. Fakat bu durum detoksifikasyonun yeterli olmadığı șeklinde değerlendirilmektedir.

Aflatoksinlerin sağlık üzerine olumsuz etkileri ve ülke ekonomisi açısından kayıplar düșünüldüğünde izlenebilirliğin önemli olduğu görülmektedir. Gıdaların ve hayvan yemlerinin üretimden tüketime kadar her așamada aflatoksin yönünden analitik yöntemlerle analizleri yapılarak kontrolleri sağlanmalıdır. Yasal düzenlemeler doğrultusunda kabul edilen sınırlardan daha yüksek değerlerde aflatoksin içeren gıda ve yemlerin tüketilmesine izin verilmemelidir. Gıda ve yemlerin küflerle kontaminasyonunun önlenebilmesi ve dolayısıyla aflatoksin olușumunun engellenebilmesi yönünde çalıșmaların artırılması gerekmektedir. Ayrıca aflatoksinin detoksifikasyonunun yeterli olmamasından dolayı kontaminasyonun kontrol altında tutulması önem tașımaktadır.

3. O'Riordan MJ, Wilkinson MG. A survey of the incidence and level of aflatoxin contamination in a range of imported spice preparations on the Irish retail market. Food Chem, 2008; 107 (4): 1429-35.

4. Rustom IYS. Aflatoxin in food and feed: Occurrence, legislation and inactivation by physical methods. Food Chem, 1997; 59 (1): 57-67. 
5. Farombi EO. Aflatoxin contamination of foods in developing countries: implications for hepatocellular carcinoma and chemopreventive strategies. Afr J Biotechnol, 2006; 5 (1): 001-14.

6. Wright MS, Greene-McDowelle DM, Zeringue HJ, Bhatnagar D, Cleveland TE. Effects of volatile aldehydes from Aspergillus-resistant varieties of corn on Aspergillus parasiticus growth and aflatoxin biosynthesis. Toxicon, 2000; 38 (9): 1215-23.

7. Gowda NKS, Malathi V, Suganthi RU. Effect of some chemical and herbal compounds on growth of Aspergillus parasiticus and aflatoxin production. Anim Feed Sci Tech, 2004; 116 (3-4): 281-91.

8. Móricz AM, Fatér Z, Otta KH, Tyihák E, Mincsovics E. Overpressured layer chromatographic determination of aflatoxin $B_{1}, B_{2}, G_{1}$ and $G_{2}$ in red paprika. Microchem J, 2007; 85 (1): 140-4.

9. Şener S. Gıda güvenliği açısından mikotoksinler. Türkiye Klinikleri J Surg Med Sci, 2006; 2 (46): 135-9.

10. Çoksöyler N. Farklı yöntemlerle kurutulan kırmızıbiberlerde Aspergillus flavus gelișimi ve aflatoksin olușumunun incelenmesi. Gıda, 1999; 24 (5): 297- 306

11. Arrus K, Blank G, Abramson D, Clear R, Holley RA. Aflatoxin production by Aspergillus flavus in Brazil nuts. J Stored Prod Res, 2005; 41 (5): 513-27.

12. Odoemelam SA, Osu C I. Aflatoxin $\mathrm{B}_{1}$ contamination of some edible grains marketed in Nigeria. E-J Chem, 2009; 6 (2): 308-14.

13. Molina M, Giannuzzi L. Modelling of aflatoxin production by Aspergillus parasiticus in a solid medium at different temperatures, $\mathrm{pH}$ and propionic acid concentrations. Food Res Int, 2002; 35 (6): 585-94.

14. Bonjar GHS. Incidence of aflatoxin producing fungi in early split pistachio nuts of Kerman, Iran. J Biol Sci, 2004; 4 (2): 199-202.

15. Giorni P, Battilani P, Pietri A, Magan N. Effect of aw and $\mathrm{CO} 2$ level on Aspergillus flavus growth and aflatoxin production in high moisture maize postharvest. Int J Food Microbiol, 2008; 122 (1-2): 109-13.
16. Bhat R, Rai RV, Karim AA. Mycotoxins in food and feed: present status and future concerns. Compr Revi Food Sci F, 2010; 9 (1): 57-81.

17. Coppock RW, Christian RG. Aflatoxins. In: Gupta RC, ed. Veterinary Toxicology: Basic and Clinical Principles. New york: Academic Press, 2007: 939-50.

18. Zheng Z, Humphrey CW, King RS, Richard JL. Validation of an ELISA test kit for the detection of total aflatoxins in grain and grain products by comparison with HPLC. Mycopathologia, 2005; 159 (2): 255-63.

19. Verma RJ. Aflatoxin cause DNA damage. Int J Hum Genet, 2004; 4 (4): 231-6.

20. Reddy L, Odhav B, Bhoola K. Aflatoxin $B_{1}$-induced toxicity in HepG2 cells inhibited by carotenoids: morphology, apoptosis and DNA damage. Biol Chem, 2006; 387 (1): 87-93.

21. Banu N, Muthumary J. Taxol as chemical detoxificant of aflatoxin produced by Aspergillus flavus isolated from sunflower seed. Health, 2010; 2 (7): 789-95.

22. Samarajeewa U, Arseculeratne SN, Tennekoon GE. Spontaneous and experimental aflatoxicosis in goats. Res Vet Sci, 1975; 19 (3): 269-77.

23. Safara M, Zaini F, Hashemi SJ, Mahmoudi M, Khosravi AR, Shojai-Aliabadi F. Aflatoxin detoxification in rice using citric acid. Iranian J Publ Health, 2010; 39 (2): 24-9.

24. Inan F, Pala M, Doymaz I. Use of ozone in detoxification of aflatoxin $B_{1}$ in red pepper. J Stored Prod Res, 2007; 43 (4): 425-9.

25. Yousef $\mathrm{AE}$, Marth $\mathrm{EH}$. Use of ultraviolet energy to degrade aflatoxin $M_{1}$ in raw or heated milk with and without added peroxide. J Dairy Sci, 1986; 69 (9): 2243-7.

26. Kabak B, Dobson ADW, Vara I. Strategies to prevent mycotoxin contamination of food and animal feed: a review. Crit Rev Food Sci Nutr, 2006; 46 (8): 593-619. 
27. Thanaboripat D, Kraipeerapun K, Pattanaphongsak C, Srisanan S, Nanasombat S. Detoxification of aflatoxin by Streptococcus lactis and lactic acid bacteria in commercial yoghurt. Kasetsart J-Nat Sci, 1997; 31: 117-23.

28. Leibetseder J. Decontamination and detoxification of mycotoxins. In: Mosenthin R, Zentek J, Zebrowska T, eds. Biology of Nutrition in Growing Animals. Elsevier Limited, 2006: 439-65.

29. Salem NM, Ahmad R. Mycotoxins in food from Jordan: Preliminary survey. Food Control, 2010; 21 (8): 1099-103.

30. Papp E, H-Otta K, Záray G, Mincsovics E. Liquid chromatographic determination of aflatoxins. Microchem J, 2002; 73 (1-2): 39-46.

31. Özturan K, Ünsal C, Karakaya Y, Atasever M, Ceylan ZG, Atasever MA. Erzurum'da tüketime sunulan buğday unlarının toplam aflatoksin, aflatoksin.B1 ve Okratoksin A Yönünden İncelenmesi. Atatürk Üniversitesi Vet Bil Derg, 2007; 2 (4): 172-6.

32. Sabuncuoğlu SA, Baydar T, Giray B, Şahin G. Mikotoksinler: Toksik etkileri, degredasyonları, olușumlarının önlenmesi ve zararlı etkilerinin azaltılması. Hacettepe Üni Ecz Fak Derg, 2008; 28 (1): 63-92.

33. Koirala P, Kumar S, Yadav BK, Premarajan KC. Occurrence of aflatoxin in some of the food and feed in Nepal. Indian J Med Sci, 2005; 59 (8): 331-6.

34. Hussain HS, Brasel JM. Toxicity, metabolism, and impact of mycotoxins on humans and animals. Toxicology, 2001; 167 (2): 101-34.

35. Oveisi MR, Jannat B, Sadeghi N, Hajimahmoodi $M$, Nikzad A. Presence of aflatoxin $M_{1}$ in milk and infant milk products in Tehran, Iran. Food Control, 2007; 18: 1216-8.

36. Anonymous. Some naturally-occurring substances: food items and constituents, heterocyclic aromatic amines and mycotoxins. Lyon: IARC monographs, 1993; 56: 359-62.

37. Ayub MY, Sachan DS Dietary factors affecting aflatoxin $B_{1}$ carcinogenicity. Mal J Nutr, 1997; 3: 161-79.
38. Singh VP. Aflatoxin biotransformations: Biodetoxification aspects. Prog Ind Microbiol, 1995; 32: 51-61.

39. Liu Y, Wu F. Global burden of aflatoxin-induced hepatocellular carcinoma: a risk assessment. Environ Health Perspect, 2010; 118 (6): 818-24.

40. Galy O, Chemin I, Le Roux E, Villar S, Le CalvezKelm F, Lereau M. Mutations in TP53 and CTNNB1 in relation to hepatitis $B$ and $C$ infections in hepatocellular carcinomas from Thailand. Hepat Res Treat, 2011; 2011: 1-9.

41. Mızrak D, Engin B, Onder FO, Yener B, Bektaș M, Biyikli Z, Idilman R. Aflatoxin exposure in viral hepatitis patients in Turkey. Turk J Gastroenterol, 2009; 20 (3): 192-7.

42. Çolak H, Bingol EB, Hampikyan H, Nazlı B. Determination of aflatoxin contamination in redscaled, red and black pepper by ELISA and HPLC. J Food Drug Anal, 2006; 14 (3): 292-6.

43. Yentür G, Er B,Gür Özkan $M$, Öktem BA. Determination of aflatoxins in peanut butter and sesame samples using high-performance liquid chromatography method. Eur Food Res Technol, 2006; 224 (2): 167-70.

44. Ardıç $M$, Karakaya $Y$, Atasever $M$, Durmaz $H$. Determination of aflatoxin $B_{1}$ levels in deep-red ground pepper (isot) using immunoaffinity column combined with ELISA. Food Chem Toxicol. 2008; 46: 1596-9.

45. Er B, Demirhan B, Onurdağ FK, Yentur G. Determination of aflatoxin $M_{1}$ level in milk and white cheese consumed in Ankara Region, Turkey. J Anim Vet Adv, 2010; 9 (12): 1780-4.

46. Özay G, Alperden ì. Türkiye'de yetiștirilen yerfıstıklarında (Arachis hypogaea L.) mikotoksinler. Gıda, 1989; 14 (5): 267-73.

47. Gürses M, Erdoğan A. Erzurum piyasasında satılan yerfıstığı, antepfıstığı ve bademlerin aflatoksin $B_{1}$ kontaminasyonu bakımından incelenmesi. Atatürk Üniv Ziraat Fak Derg, 2004; 35 (1-2): 75-8.

48. Gürses M. Mycoflora and aflatoxin content of hazelnuts, walnuts, peanuts, almonds and roasted chickpeas (leblebi) sold in Turkey. Int J Food Prop, 2006; 9: 395-9. 
49. Bircan C, Barringer SA, Ulken Ü, Pehlivan R. Aflatoxin levels in dried figs, nuts and paprika for export from Turkey. Int J Food Sci Tech, 2008; 43 (8): $1492-8$.

50. Aycicek H, Aksoy A, Saygi S. Determination of aflatoxin levels in some dairy and food products which consumed in Ankara, Turkey. Food Control, 2005; 16 (3): 263-6.

51. Oruç HH, Cengiz M, Kalkanli O. Comparison of aflatoxin and fumonisin levels in maize grown in Turkey and imported from the USA. Anim Feed Sci Tech, 2006; 128: 337-41.

52. Özay G, Alperden I. Aflatoxin and ochratoxin-a contamination of dried figs (Ficus carina L.) from the 1988 crop. Mycotoxin Res, 1991; 7: 85-91.

53. Giray B, Girgin G, Engin AB, Aydın S, Șahin G. Aflatoxin levels in wheat samples consumed in some regions of Turkey. Food Control, 2007; 18 (1): 23-9.

54. Aydın A, Erkan ME, Bașkaya R, Ciftcioğlu G. Determination of aflatoxin $B_{1}$ levels in powdered red pepper. Food Control, 2007; 18 (9): 1015-8.

55. Yentür G. Bazı gıda maddelerinde aflatoksin $B_{1}$ ve $M_{1}$ düzeylerinin saptanması. Gazi Üniversitesi Bilimsel Araștırma Projesi. No: 02/2009-16, 2010.

56. Demirer MA, Dinçer B, Kaymaz Ş, Alperden I, Yalçın S, Özer E. Bazı gıda maddelerinde mikroflora ve mikotoksin araștırmaları. AÜ Vet. Fak. Derg, 1989; 36 (1): 85-107.

57. Var I, Kabak B, Gök F. Survey of aflatoxin $B_{1}$ in helva, a traditional Turkish food, by TLC. Food Control, 2007; 18 (1): 59-62.

58. Gürbay A, Aydın S, Girgin G, Engin AB, Şahin G. Assessment of aflatoxin $M_{1}$ levels in milk in Ankara, Turkey. Food Control, 2006; 17 (1): 1-4.

59. Sarımehmetoğlu B, Kuplulu O, Celik TH. Detection of aflatoxin $M_{1}$ in cheese samples by ELISA. Food Control, 2004; 15 (1): 45-9.
60. Gürses $M$, Erdoğan A, Çetin B. Occurrence of aflatoxin $M_{1}$ in some cheese types sold in Erzurum, Turkey. Turk J Vet Anim Sci, 2004; 28: 527-30.

61. Elmalı M, Yapar K, Kart A, Yaman H. Aflatoksin $M_{1}$ levels in milk powder consumed in Turkey. J Anim Vet Adv, 2008; 7 (5): 643-5.

62. Ardıç M, Karakaya Y, Atasever M, Adiguzel G. Aflatoxin $M_{1}$ levels of Turkish white brined cheese. Food Control, 2009; 20 (3): 196-9.

63. Anonymous. Türk Gıda Kodeksi - 2008/26 No’lu Gıda Maddelerindeki Bulaşanların Maksimum Limitleri Hakkında Tebliğ, 2008.

64. Park JW, Kim EK, Kim YB. Estimation of the daily exposure of Koreans to aflatoxin $B_{1}$ through food consumption. Food Addit Contam, 2004; 21 (1): 70-5.

65. Anonymous. Türk Gıda Kodeksi - 2009/22 No’lu Gıda Maddelerindeki Bulașanların Maksimum Limitleri Hakkında Tebliğde Değișiklik Yapılması Hakkında Tebliğ, 2009.

66. Basaran P, Ozcan M. Occurrence of aflatoxins in various nuts commercialized in Turkey. J Food Safety, 2009; 29 (1): 95-105.

67. Pei SC, Zhang YY, Eremin SA, Lee WJ. Detection of aflatoxin $M_{1}$ in milk products from China by ELISA using monoclonal antibodies. Food Control, 2009; 20 (12): 1080-5.

68. Virdis S, Corgiolur G, Scarano C, Pilo AL, De Santis EPL. Occurrence of aflatoxin M1 in tank bulk goat milk and ripened goat cheese. Food Control, 2008; 19 (1): 44-9.

69. Torkar KG, Vengušt A. The presence of yeasts, moulds and aflatoxin $M_{1}$ in raw milk and cheese in Slovenia. Food Control, 2008; 19 (6): 570-7.

70. Saha D, Acharya D, Roy D, Shrestha D, Dhar TK. Simultaneous enzyme immunoassay for the screening of aflatoxin $B_{1}$ and ochratoxin $A$ in chili samples. Anal Chim Acta, 2007; 584 (2): 343-9. 
71. Marin S, Colom C, Sanchis V, Ramos AJ. Modelling of growth of aflatoxigenic $A$. flavus isolates from red chilli powder as a function of water availability. Int J Food Microbiol, 2009; 128 (3): 491-6.

72. Hernández-Hierro JM, García-Villanova RJ, González-Martín I. Potential of near infrared spectroscopy for the analysis of mycotoxins applied to naturally contaminated red paprika found in the Spanish market. Anal Chim Acta, 2008; 622 (1-2): 189-94.
73. Anonymous. Setting maximum levels for certain contaminants in foofdtuffs. Commision Regulation (EC) No 1881/2006. Official Journal of the European Union, 2006.

74. Anonymous. Amending Regulation (EC) No $1881 / 2006$ setting maximum levels for certain contaminants in foofdtuffs as regards aflatoxins. Commision Regulation (EU) No 165/2010.Official Journal of the European Union, 2010. 